\title{
Targeting RORs nuclear receptors by novel synthetic steroidal inverse agonists for autoimmune disorders
}

\author{
Matteo Dal Pra ${ }^{\mathrm{a}}$, Davide Carta ${ }^{\mathrm{a}}$, Gyorgy Szabadkai ${ }^{\mathrm{b}}$, Matteo Suman ${ }^{\mathrm{b}}$, Yahima Frión-Herrera ${ }^{\mathrm{a}}$, \\ Nicola Paccagnella ${ }^{\mathrm{a}}$, Giulia Castellani ${ }^{\mathrm{a}}$, Sara De Martin ${ }^{\mathrm{a}}$, Maria Grazia Ferlin ${ }^{\mathrm{a}}$ \\ a. Department of Pharmaceutical and Pharmacological Sciences, University of Padova, 35131 \\ Padova, Italy. \\ b. Department of Biomedical Sciences, University of Padova, 35131 Padova, Italy.
}

\begin{abstract}
Designing novel inverse agonists of NR ROR $\gamma t$ still represents a challenge for the pharmaceutical community to develop therapeutics for treating immune diseases. By exploring the structure of NRs natural ligands, the representative arotenoid ligands and RORs specific ligands share some chemical homologies which can be exploited to design a novel molecular structure characterized by a polycyclic core bearing a polar head and a hydrophobic tail. Compound MG 2778 (8), a cyclopenta[a]phenantrene derivative, was identified as lead compound which was chemically modified at position 2 in order to obtain a small library for preliminary SARs. Cell viability and estrogenic activity of compounds $7, \mathbf{8}, \mathbf{1 9 a}, \mathbf{3 0}, \mathbf{3 1}$ and $\mathbf{3 2}$ were evaluated to attest selectivity. The selected 7, 8, 19a and 31 compounds were assayed in a Gal4 UAS-Luc co-transfection system in order to determine their ability to modulate ROR $\gamma$ t activity in a cellular environment. They were evaluated as inverse agonists taken ursolic acid as reference compound. The potency of compounds was lower than that of ursolic acid, but their efficacy was similar. Compound 19a was the most active, significantly reducing ROR $\gamma t$ activity at low micromolar concentrations.
\end{abstract}

Key words: NR ROR $\gamma$ t, inverse agonists, Gal4 UAS-Luc co-transfection, autoimmune disorders

\section{Introduction}

Nuclear receptors (NRs) form a family of transcription factors that are composed of modular protein structures with DNA- and ligand-binding domains (DBDs and LBDs). The DBDs confer gene target site specificity, whereas LBDs serve as control switches for NR function. In each case the overall fold of the LBD is conserved and the ligand is bound entirely within the protein, completing the 
core as the protein refolds around it. ${ }^{1}$ It was shown that despite the chemical diversity of the natural nuclear receptor ligands, their volumes are highly conserved. ${ }^{2}$
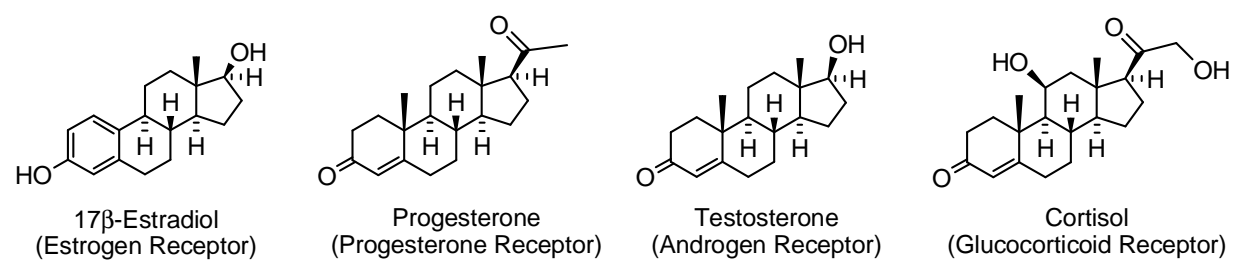
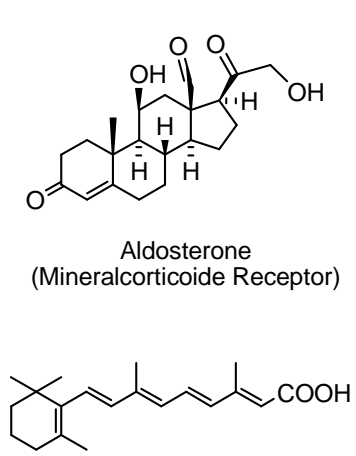

All-trans Retinoic Acid (Retinoic acid receptor)

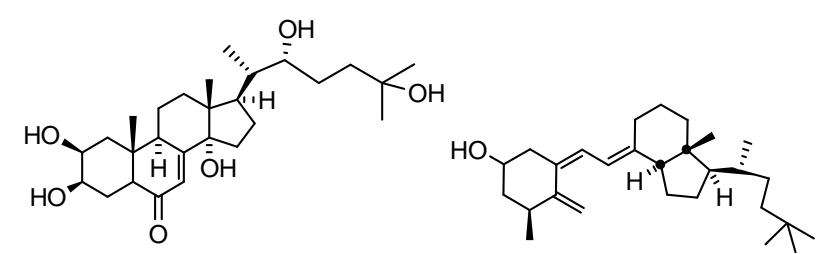

Ecdysone
(Ecdysone Receptor)

$1 \alpha, 25$-Dihydroxyvitamin $D_{3}$ (Vitamin $\mathrm{D}_{3}$ Receptor)
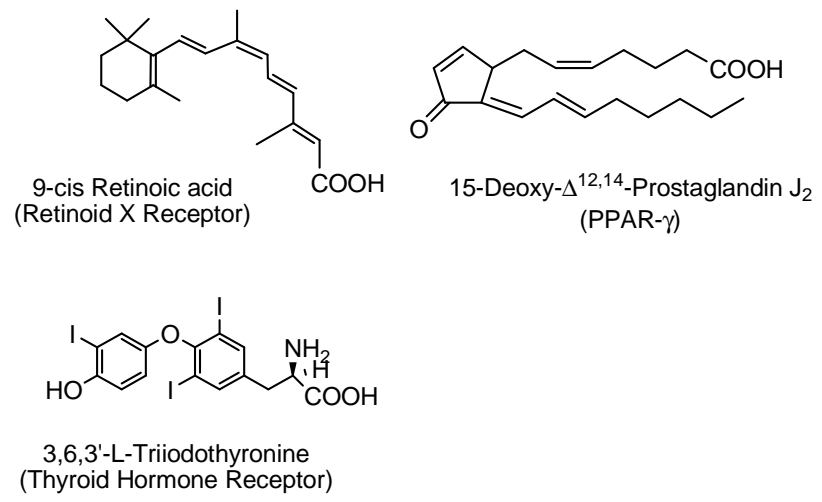

Figure 1. The natural ligands of nuclear receptors ${ }^{2}$

For many NRs, both endogenous and synthetic small molecule ligands bind to small pockets within the LBDs, resulting in conformational changes that regulate transcriptional activity. This property of NRs has proven to be a rich source as targets for developing of therapeutics for a myriad of human diseases, ranging from inflammatory diseases and cancer to endocrine and metabolic diseases. $^{3}$

The retinoic acid nuclear receptors subfamily includes $\operatorname{RAR} \alpha, \operatorname{RAR} \beta$ and $\operatorname{RAR} \gamma$ and it is evolutionarily closed to the retinoic acid receptor-related orphan receptors subfamily, which is constituted by $\operatorname{ROR} \alpha, \operatorname{ROR} \beta$ and $\operatorname{ROR} \gamma$ or RORc. ROR $\gamma$ t is a splice variant of $\operatorname{ROR} \gamma$ and is encoded by a single gene called RORc. ROR $\gamma t$ is selectively expressed in thymocytes (T cells) and appears to drive the activation and differentiation of CD4+ and CD8+ cells into IL17-producing T helper cells $\left(\mathrm{T}_{\mathrm{H}} 17\right)$ and cytotoxic $\mathrm{T}$ cells $(\mathrm{Tc} 17) . \mathrm{T}_{\mathrm{H}} 17$ and $\mathrm{Tc17}$ are effector cells that promote inflammation, adaptive immunity, and autoimmunity by producing IL17 and other inflammatory cytokines such as IL21. Both synthetic and putative endogenous agonists of ROR $\gamma \mathrm{t}$ have been 
shown to increase the basal activity of ROR $\gamma t$ enhancing $\mathrm{T}_{\mathrm{H}} 17$ cell proliferation. Among the various transcriptional regulators $\mathrm{ROR} \gamma$ is a uniquely tractable drug target for manipulating $\mathrm{T}_{\mathrm{H}} 17$ cell development and function in the context of autoimmune diseases. ${ }^{4}$ The ROR $\gamma t$ LBD is an ideal domain to target via small molecules. Small molecules targeting RORs come in at least two types: inverse agonists, which block ROR-dependent transcriptional activity; and agonists, which enhance the transactivation of RORs. ${ }^{5}$

Table 1. Structure of RORs ligands ${ }^{7}$

\begin{tabular}{|c|c|c|c|c|}
\hline Name & Structure & $\begin{array}{c}\text { Receptor } \\
\text { preferences }\end{array}$ & $\begin{array}{c}\text { Ligand } \\
\text { type }\end{array}$ & Ref. \\
\hline Т0901317 & & $\begin{array}{l}\text { ROR } \alpha, \text { ROR } \gamma, \\
\text { LXR } \alpha, \text { LXR } \beta \text {, } \\
\text { PXR, FXR, other }\end{array}$ & $\begin{array}{c}\text { RORs: } \\
\text { inverse } \\
\text { agonist } \\
\text { LXRS, } \\
\text { PXR, } \\
\text { FXR: } \\
\text { agonist }\end{array}$ & $8 ; 9$ \\
\hline SR1001 & & $\begin{array}{l}\text { ROR } \alpha \\
\operatorname{ROR} \gamma\end{array}$ & $\begin{array}{l}\text { Inverse } \\
\text { agonist }\end{array}$ & 11 \\
\hline SR1078 & & $\begin{array}{l}\text { ROR } \alpha \\
\operatorname{ROR} \gamma\end{array}$ & Agonist & 12 \\
\hline SR3335 & & $\mathrm{ROR} \alpha$ & $\begin{array}{l}\text { Inverse } \\
\text { agonist }\end{array}$ & 6 \\
\hline SR2211 & & $\mathrm{ROR} \gamma$ & $\begin{array}{l}\text { Inverse } \\
\text { agonist }\end{array}$ & 12 \\
\hline TMP778 & & $\mathrm{ROR} \gamma$ & $\begin{array}{l}\text { Inverse } \\
\text { agonist }\end{array}$ & 13 \\
\hline TMP920 & & $\mathrm{ROR} \gamma$ & $\begin{array}{l}\text { Inverse } \\
\text { agonist }\end{array}$ & 13 \\
\hline GSK805 & & $\mathrm{ROR} \gamma$ & $\begin{array}{l}\text { Inverse } \\
\text { agonist }\end{array}$ & 13 \\
\hline
\end{tabular}




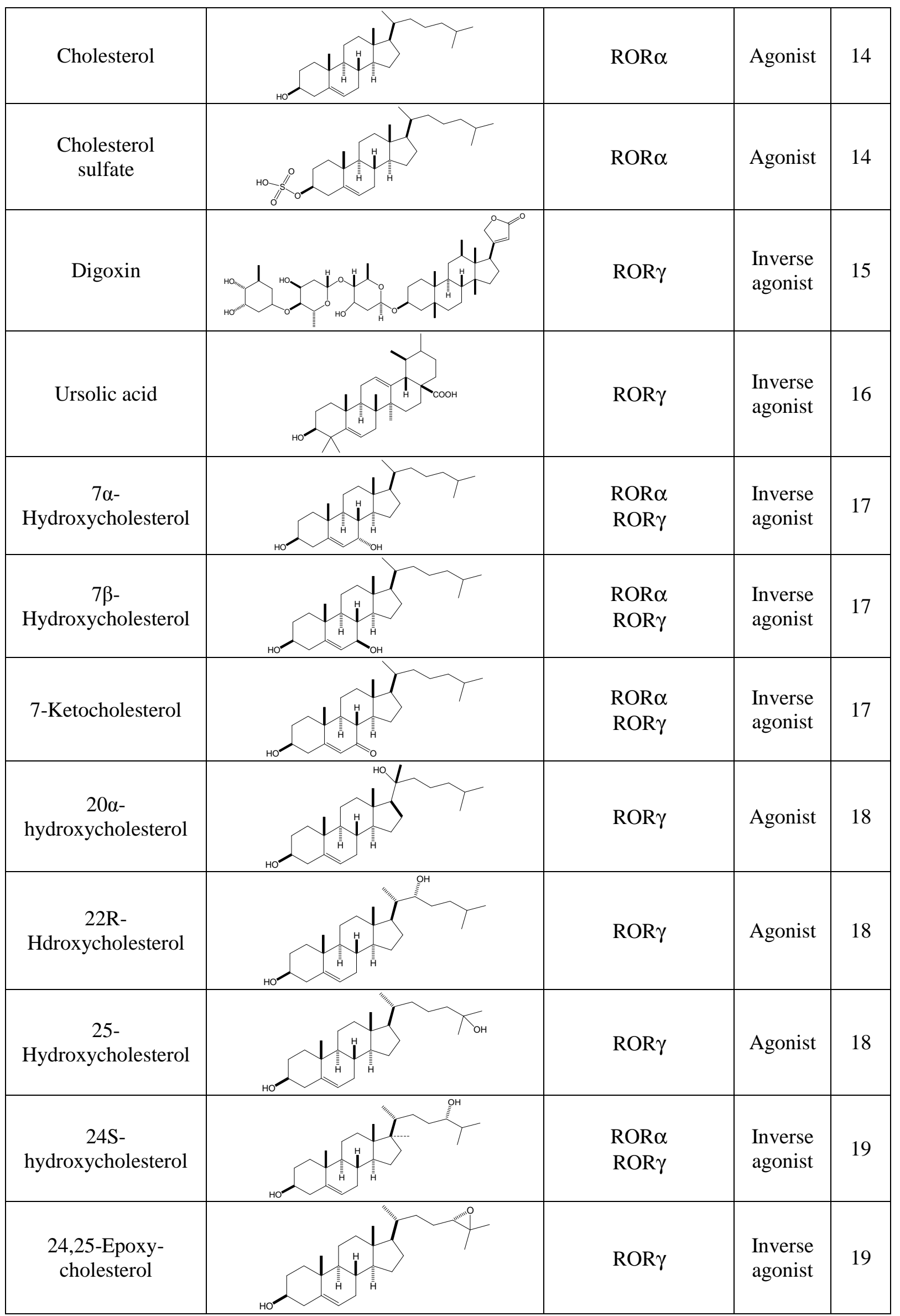




\begin{tabular}{|l|l|l|l|l|}
\hline $\begin{array}{c}\text { 24R- } \\
\text { Hydroxycholesterol }\end{array}$ & ROR $\gamma$ & $\begin{array}{c}\text { Inverse } \\
\text { agonist }\end{array}$ & 19 \\
\hline
\end{tabular}

Since the discovery of the first small molecule T0901317,8,9 (Table 1), many ROR $\gamma t$ ligands with agonistic and inverse agonistic activity have been disclosed in the literature. ${ }^{7,10}$ Using the T0901317 scaffold as a lead compound, a series of synthetic ROR $\gamma$ inverse agonists have been developed, including SR1001, SR1555, and SR2211. ${ }^{6-11}$ Some structurally complex natural products, such as digoxin and ursolic acid have also been reported to be ROR $\gamma$ inverse agonists. ${ }^{15,16}$ Dan Littman's group, who discovered the crucial role for ROR $\gamma t$ in $\mathrm{T}_{\mathrm{H}} 17$ cells, identified the cardiac glycoside digoxin as a specific inhibitor for $R O R \gamma t$ transcriptional activity using a chemical library screening. ${ }^{15}$ They confirmed that digoxin inhibited murine $\mathrm{T}_{\mathrm{H}} 17$ cell differentiation without affecting other $\mathrm{T}$ cell lineages, and it was efficient in a mouse EAE model. Digoxin was also identified in a random screening campaign, as an inhibitor of mouse and human $\mathrm{T}_{\mathrm{H}} 17$ cell differentiation, and the crystal structure of the LBD of ROR $\gamma$ t in complex with digoxin at $2.2 \mathrm{~A}^{\circ}$ resolution has been solved. (Fig. 2). ${ }^{15,17}$

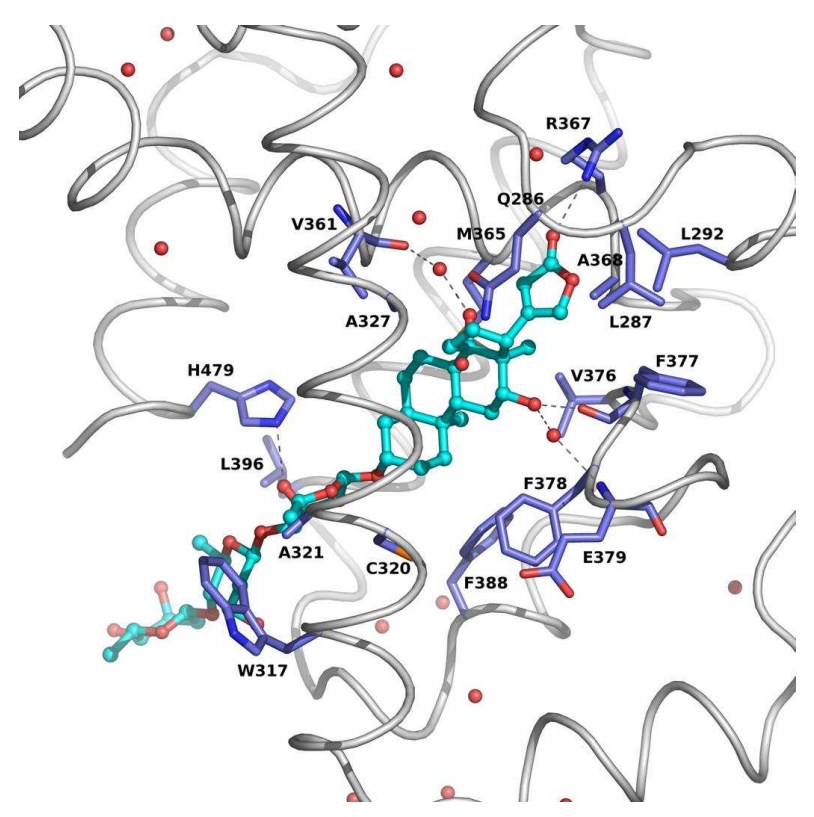

Figure 2. Digoxin binding mode in the ROR $\gamma$ t ligand binding domain. ${ }^{15}$

Ursolic acid, another natural product, was also found in a compound library screening as an inhibitor of ROR $\gamma t .{ }^{16}$ Importantly, both digoxin and ursolic acid have cholesterol-like chemical structures, which might account for their similar action on the NR. 
Recently, a team at Genentech identified N-isobutyl- N-((5-(4-(methylsulfonyl)phenyl)thiophen-2yl)methyl)-1-phenylmethanesulfonamide as a ROR $\gamma \mathrm{t}$ inverse agonist via a biochemical screening campaign. ${ }^{20}$ Although the development of ROR $\gamma t$ inverse agonists has shown significant promise, 21,22 the development of new ROR $\gamma$ t selective modulators with therapeutic potential still remains an urgent need.

Wang et al. $^{23}$ first reported that the natural products $7 \alpha$-hydroxycholesterol ${ }^{17}$ and $24 \mathrm{~S}$ hydroxycholesterol $^{19}$ were inverse agonists (i.e. functional antagonists) of ROR $\alpha$ and ROR $\gamma$ that suppressed transcriptional activities in hepatocytes. Oxysterols are well known natural ligands for the related NR including the liver $X$ receptor (LXR), therefore their interaction with the LBDs of RORs was not surprising. ${ }^{24}$ Most small molecule inhibitors and drugs are based on cyclic systems, which leads to a stiffening of the molecule, resulting in enhanced target affinity due to less entropy loss upon binding. The structural homology of NRs suggested to evaluate ligands for other class of receptors as possible cognate compounds that opportunely modified could switch their target classes becoming specific RARs/RORs agonists or inverse agonists.

\subsection{Designing a lead compound}

Very recently, the authors were involved in expanding their research in the field of inflammatory and auto-immune diseases, by modulating the activity of NRs. Looking through the NRs superfamily and the chemical variety of the ligands scaffolds (polyenes, polycyclic compounds, aromatic or aliphatic rings, eicosanoids, farnesoids, oxysterols, and tryptamine) (Figure 1), it could seem very unlikely that a novel ROR $\gamma$ inverse agonist lead candidate could be designed. However, the authors decide to explore the possibility to target ROR $\gamma$ receptor with a novel lead candidate, characterized by a cyclopenta[a]phenantrene scaffold. The design of a novel ROR $\gamma$ inverse agonist lead candidate was rationalized by means of a structure-based approach founded on hybridization of chemical structures, which mix the features of ROR $\gamma$ natural ligands (cholesterol-like derivatives, digoxin, ursolic acid) with the features of representative arotenoids (Figure 3). ${ }^{24}$ This choice was made because RARs and RORs receptors are evolutionarily closed and shared sequence homology. ${ }^{6}$

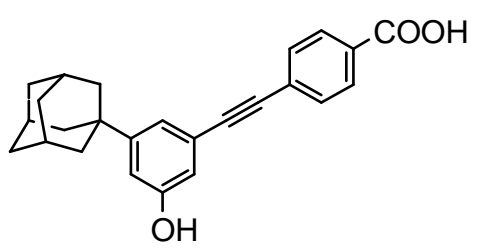

20.7

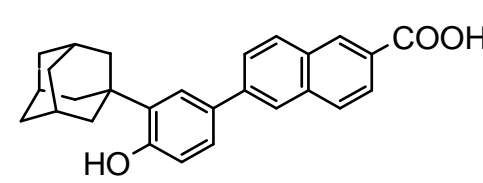

CD437<smiles>O=C(O)c1ccc(C2C=Cc3cc(C45CC6CC(CC4C6)C5)c(O)cc3C=CC2)cc1</smiles>

CD153

Figure 3. Arotenoids selective ligands 
The envisaged novel RORs inverse agonist may result then conceptually defined by the following attributes:

1) A central polycyclic fused structure is present in other natural ligands of different classes of NRs assuring a suitable molecular volume to fulfill the LBD of the ROR receptors. The conservation of volumes among the natural ligands of nuclear receptors is likely to be a useful criterion in the design of high-affinity analogs. ${ }^{2}$ It serves as a linker and supporting structure for the other fundamental chemical functions necessary for delivering the biological activity of the compound.

2) An aromatic ring as usually represented in $\operatorname{arotenoids}^{24}$

3) A large lipophilic scaffold (cyclic, polycyclic or poly methylated scaffold) mimicking the cyclic RA function or other bulky substituents connected to the polycyclic linker

4) A polar terminus corresponding to or mimicking the RA and ursolic acid acidic function (COOH or any of the known bioisosters or derivatives)

5) A hydroxylic function, as represented in arotenoids, cholesterol-like ligands and ursolic acid The molecular structure of a lead compound might be the tetracycle MG 2778 as shown in Figure 4:

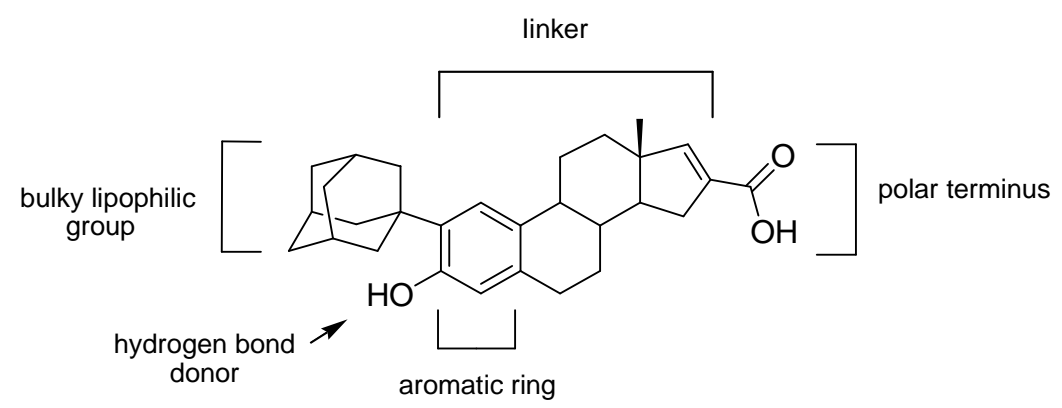

Figure 4. Lead structure of MG 2778. The molecule can be divided into three parts: an acidic head, a cyclopenta[a]phenantrene backbone, and a lipophilic tail. The activity was investigated after structural modification of lipophilic group.

The early objective was to develop an efficient synthetic path for obtaining the proposed compound as described in Figure 4 (MG 2778). MG 2778 is a cyclopenta[a]phenantrene derivative bearing an adamanthyl group at 2 position. This large group in position 2 was placed also because it was found to be effective in reducing hormonal effects of estrone and estradiol analogs in non-feminizing neuroprotective agents and so preventing estrogen receptor binding. ${ }^{25}$ It also has an $\alpha-\beta$-unsaturated carboxylic group at 16 and a phenolic hydroxyl at position 3. Next, with the aim to obtain preliminary SARs, a small series of analogs modified at position 2 of the polycyclic nucleus with 
groups other than adamanthyl but maintaining the lipophilic and bulky features was planned, since a suitable substitution at this position is considered significant for giving selectivity. To synthesize 2substituted analogs we adopted methods such as Friedel-Crafts alkylation, acylation and SuzukiMiyaura cross-coupling reactions on aromatic ring. Six compounds $(\mathbf{7}, \mathbf{8}, \mathbf{1 9 a}, \mathbf{3 0 - 3 2})$ were tested for cytotoxicity and estrogen receptor activity. The selected four non-cytotoxic compounds (7, 8, 19a, 31) were assayed in a Gal4 UAS-Luc co-transfection system in order to determine their ability to modulate ROR $\gamma$ t activity in a cellular environment. They were evaluated as inverse agonists taken ursolic acid as reference compound. ${ }^{26}$ Results from the synthetic work and preliminary biological evaluation are reported.

\section{Results and Discussion}

\subsection{Docking simulations of MG 2778 (8) in ROR $\gamma t$ LBD}

We further employed molecular modelling analysis to simulate MG 2778 (8) binding in the ROR $\gamma \mathrm{t}$ binding pocket. We selected the crystal structure of ROR $\gamma \mathrm{t}$ in complex with one of the best-known inverse agonists, digoxin (PDB code $3 \mathrm{~B} 0 \mathrm{~W}) .{ }^{27}$ Computer docking simulation of compound 8 was performed using Maestro 10.5 Glide software SP precision.

Figure 5 shows the binding mode of the most favoured pose of compound $\mathbf{8}$ in the presumptive binding site in comparison with digoxin. We found that compound $\mathbf{8}$ could be readily accommodate in the pocket. Moreover, ROR $\gamma \mathrm{t}$ shows a binding pocket mostly characterized by hydrophobic residues (Leu-287, Leu-292, Trp-317, Cys-320, Ala-321, Ala-327, Val-361, Met-365, Ala-368, Val376, Phe-377, Phe-378, Phe-388, Leu-396) which suggests a binding interaction mode mainly characterised by hydrophobic interactions. No direct interaction between compound $\mathbf{8}$ and the residues responsible for digoxin binding was found. ${ }^{15}$ However, even if the molecular volume of compound $\mathbf{8}$ is smaller than that of digoxin, it is possible that the bulky substituent in position 2 of the cyclopenta[a]phenanthrene core (which occupies the position of the first sugar ring in digoxin) might be sufficient to disturb the polar interactions observed in the agonist-bound ROR $\gamma \mathrm{t}$ LBD, involving His-479, Tyr-502 and Phe-506 which would be important to stabilize the active conformation of helix $\mathrm{H} 12 .^{15,17}$ 


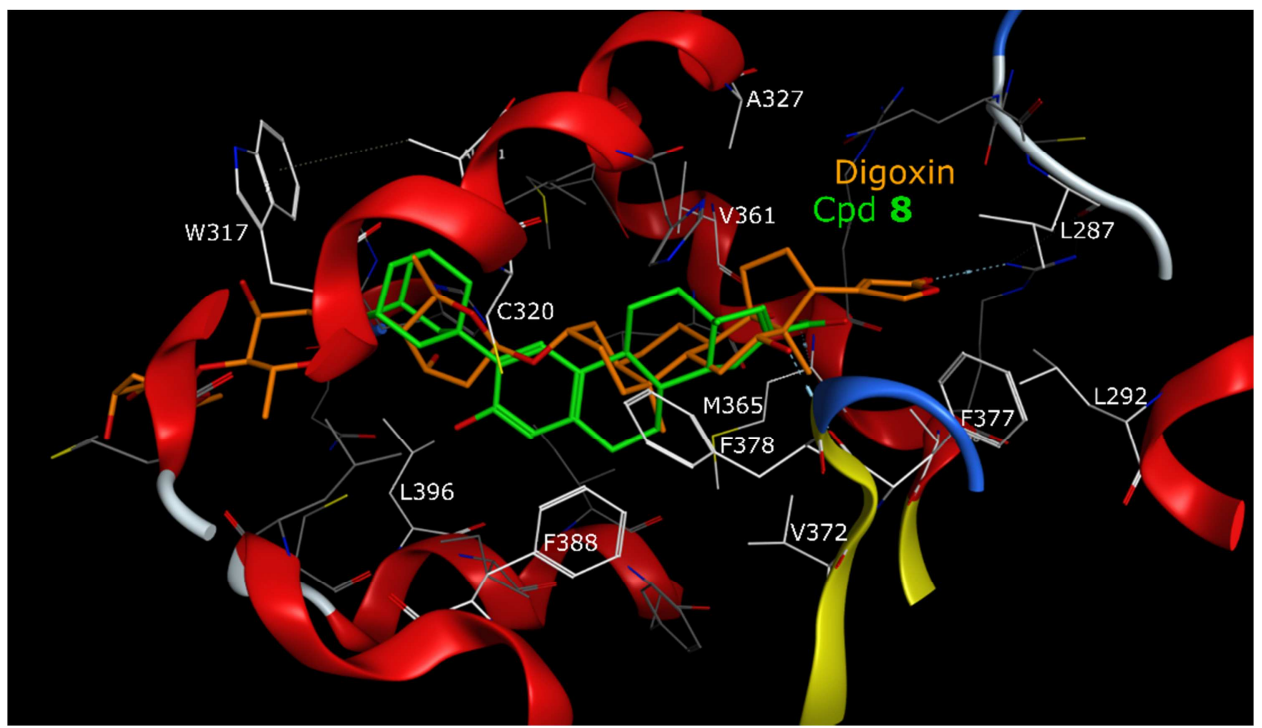

Figure 5. Comparison of the crystallographic structure of digoxin (in orange) in complex with ROR $\gamma \mathrm{t}$ ligand binding domain (Protein Data Bank code 3B0W) and the energetically most favourable pose of compound 8 (in green) obtained by molecular docking simulation. Hydrophobic residues are shown in white. Hydrogen atoms are omitted.

\subsection{Chemistry}

The synthetic work has been organized into four schemes that describe the optimized synthetic pathways as a result of trials to improve yields and purity of reaction products. The schemes report the routes carrying to final compounds for the synthesis of which the pre-formed polycyclic scaffold 3-hydroxyestra-1,3,5(10)-triene-17-one (estrone) was selected as starting material. In all cases, the early protection of phenolic $\mathrm{OH}$ was necessary to prevent unresolvable mixtures formation along the pathway. Schemes 1 and 2 describe two alternative routes to obtain compound 8 (named MG 2778) by performing the same reactions in a different order. For this purpose, intermediate 1 was obtained from the starting commercial estrone by alkylating with $\mathrm{CH}_{3} \mathrm{I}$ in the presence of $\mathrm{Bu}_{4} \mathrm{NI}$ and $\mathrm{NaOH} 10 \%$ in $\mathrm{CH}_{2} \mathrm{Cl}_{2}$ at $70^{\circ} \mathrm{C}(99 \%$ yield $) .{ }^{28}$ As previously reported, ${ }^{29}$ compound 1 was submitted to a Friedel-Crafts reaction conducted with adamanthanol, $\mathrm{BF}_{3} \mathrm{Et}_{2} \mathrm{O}$ in hexane for $4 \mathrm{~h}$. The reaction proved to be highly region-specific yielding only the 2-adamanthyl substituted compound 2 (95\%yield). The following 16-C methoxycarbonylation reaction ${ }^{30}$ was carried out with dimethyl carbonate, $\mathrm{NaH}$ at refluxing $\left(85^{\circ} \mathrm{C}\right.$ ) for $3 \mathrm{~h}$ yielding compound 3 (yield 93\%). In order to form the 16-17 double bond, at first the 17-carbonyl group was reduced to secondary alcohol 4 by a chemoselective reaction with $\mathrm{NaBH}_{4}{ }^{31}$ in a mixture of $\mathrm{THF} / \mathrm{CH}_{3} \mathrm{OH}$ 9:1 for $1 \mathrm{~h}$ at room temperature (yield 90\%). The obtained alcohol 4 was mesylated with $\mathrm{MsCl}$ in anhydrous $\mathrm{CH}_{2} \mathrm{Cl}_{2}{ }^{32}$ giving the intermediate ester 17-methylsulfonate 5 , which by treatment with $\mathrm{DBU}$ in benzene ${ }^{32}$ for $6 \mathrm{~h}$ at $60^{\circ} \mathrm{C}$ and after Flash Chromatography purification, furnished the precursor intermediate 6 (60\% yield). 
The last step to produce the designed compound $\mathbf{8}$ was attempted with various hydrolytic methods and most of them failed. Among all, the treatment with, $\mathrm{MeOH}, \mathrm{NaOH} 2 \mathrm{M}$, in $\mathrm{CH}_{2} \mathrm{Cl}_{2}{ }^{33}$ for $96 \mathrm{~h}$ gave the acid derivative 7 by $95 \%$ yield and only the method involving the use of $\mathrm{NaSCH}_{3}$ in NMP at refluxing for $9 \mathrm{~h}^{34}$ was successful in giving the desired compound 8 with a yield of $56 \%$.

Scheme 1. Synthesis of compound $\mathbf{8}$

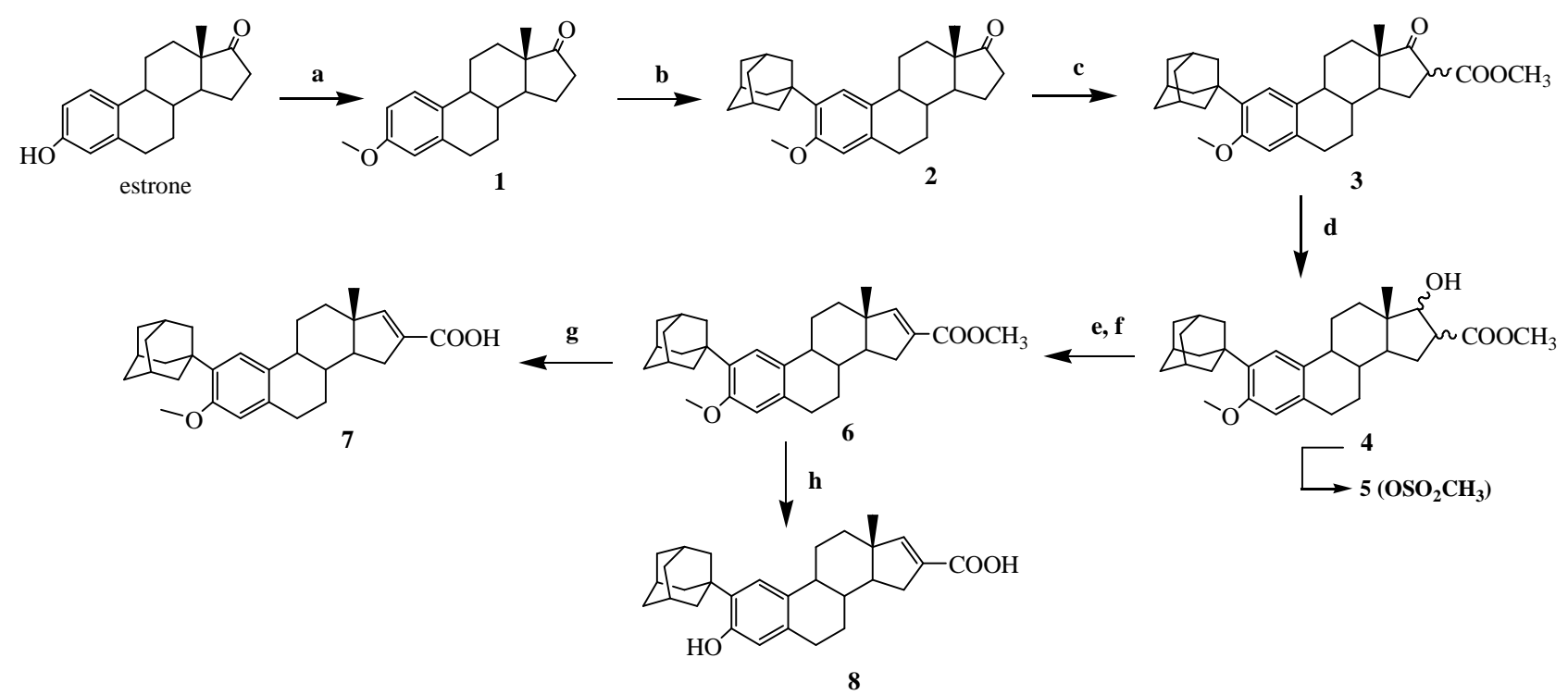

Reagents and conditions: a) $\mathrm{CH}_{3} \mathrm{I}, \mathrm{Bu}_{4} \mathrm{~N}+\mathrm{I}-, \mathrm{CH}_{2} \mathrm{Cl}_{2}, \mathrm{NaOH} 10 \%$, ref., 3h, 99\%; b) 1-adamantanol, $\mathrm{BF}_{3} \mathrm{Et}_{2} \mathrm{O}$, hexane, 4h, 95\%; c) $\mathrm{C}_{3} \mathrm{H}_{6} \mathrm{O}_{3}, \mathrm{NaH}$, ref., 3h, 93\%; d) $\mathrm{NaBH}_{4}, \mathrm{THF} / \mathrm{CH}_{3} \mathrm{OH}$ 9:1, 1h, 90\%; e) $\mathrm{MsCl}, \mathrm{Et}_{3} \mathrm{~N}$, anhydrous $\mathrm{CH}_{2} \mathrm{Cl}_{2}$; f) DBU, $\mathrm{C}_{6} \mathrm{H}_{6}$, ref., 6h, 60\%; g) NaOH, $\mathrm{MeOH}, \mathrm{CH}_{2} \mathrm{Cl}_{2}, 96$ h, $90 \%$; h) $\mathrm{NaSCH}_{3}$, NMP, ref., 9h, 56\%.

In scheme 2, the route to compound $\mathbf{8}$ was set up in an attempt to improve the work up of reaction mixtures. Indeed, through the previous reactions scheme 1, with compounds bearing the 2adamanthyl substitution the procedure resulted difficult. Thus, the adamanthyl moiety was inserted at the end of the pathway. Henceforward, compound $\mathbf{1}$ was transformed into the 16methoxycarbonylated derivative $\mathbf{9}^{30}(93 \%)$ that was reduced to the 17 -hydroxylic derivative $\mathbf{1 0}^{31}$ (60\%). Then, the last was mesylated to compound $\mathbf{1 1}$ and this reacting with DBU produced the precursor compound $\mathbf{1 2}^{32}$ (84\%) showing the 16-17 double bond. At this point, the introduction of the adamanthyl group again produced only compound 6 but unfortunately with low yields (12\%). ${ }^{29}$ Evidently, the presence of the 16-17 double bond provoked the formation of byproducts in the F-C reaction. Following, compound $\mathbf{1 3}$ gave the described acid $\mathbf{8}$ by reacting with $\mathrm{NaSCH}_{3}$ and NMP at reflux. ${ }^{34}$ Accordingly, by comparing the two synthetic pathways (scheme 1 and 2), it was concluded that by the pathway in scheme 2 the scope to facilitate the synthetic work was achieved, but despite 
the laborious work up, the pathway in scheme 1 was undoubtedly the more advantageous because of the higher yields.

Scheme 2. An alternative pathway for the synthesis of compound $\mathbf{8}$

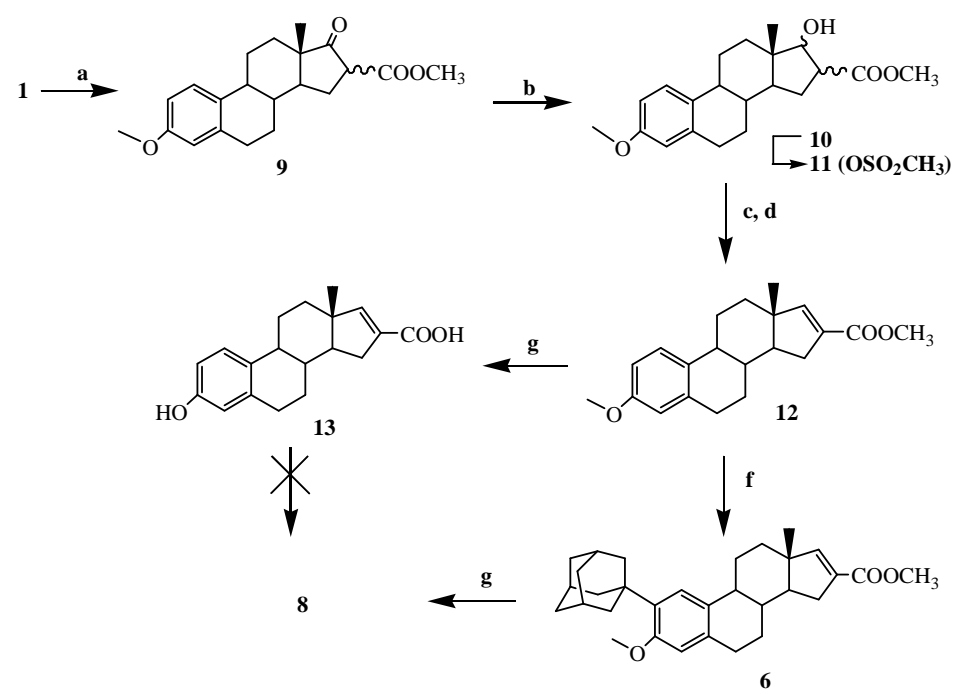

Reagents and conditions: a) $\mathrm{C}_{3} \mathrm{H}_{6} \mathrm{O}_{3}, \mathrm{NaH}$, ref., 3h, 95\%; b) $\mathrm{NaBH}_{4}, \mathrm{THF} / \mathrm{CH}_{3} \mathrm{OH} 9: 1,1 \mathrm{~h}, 60 \%$; c) $\mathrm{MsCl}_{2} \mathrm{Et}_{3} \mathrm{~N}$, anhydrous $\mathrm{CH}_{2} \mathrm{Cl}_{2}, 84 \%$; d) $\mathrm{DBU}, \mathrm{C}_{6} \mathrm{H}_{6}$, ref., 6h, 99\%; e) $\mathrm{NaOH}, \mathrm{MeOH}, \mathrm{CH}_{2} \mathrm{Cl}_{2}, 96$ h, $90 \%$; f) 1-adamanthanol, $\mathrm{BF}_{3} \mathrm{Et}_{2} \mathrm{O}$, hexane, $4 \mathrm{~h}, 12 \%$; g) $\mathrm{NaSCH}_{3}$, NMP, ref., $5 \mathrm{~h}, 32 \%$.

Next, in view of the synthesis of various 2-substituted analogs of $\mathbf{8}$, the synthetic work has proceeded with an assessment of the reactivity of 3-methoxylated estrone 1 towards the FriedelCrafts (F-C) acylation and the Suzuky-Miyaura (S-M) cross-coupling reaction. For this purpose, following the above useful pathway and carrying out the same kind of reactions as in scheme 1, scheme 3 describes the synthesis of 2-benzoyl-compound 14. The 3-methoxy-estrone 1 was submitted to the $\mathrm{F}-\mathrm{C}$ reaction with benzoyl chloride in the presence of $\mathrm{AlCl}_{3}$ in $\mathrm{CH}_{2} \mathrm{Cl}_{2}$ at $0^{\circ} \mathrm{C}$ for 3 h. ${ }^{35}$ In this case, a mixture of three compounds was obtained that were separated by Flash Chromatography. As expected, due to the more electron-rich position 2, the 2-benzoyl-3-methoxyderivative 14a was retrieved in greater amount (58\%), the 4-benzoyl-methoxy isomer 14b (31\%) and in lesser amount the 2-benzoyl-3-hydroxy derivative 14c (2\%). The last formed due to the demethylating property of reaction conditions. Compound $\mathbf{1 4 a}$ was then transformed into the 16methoxycarbonylated derivative $\mathbf{1 5}(33 \%)^{30}$ before being selectively reduced to the 17-hydroxylic compound 16 by $\mathrm{NaBH}_{4}(97 \%) .{ }^{31}$ This compound was first mesylated $\left(\mathbf{1 7}, 17-\mathrm{OSO}_{2} \mathrm{CH}_{3}\right)^{32}$ and thereafter by treatment with DBU, compound $18(17-\mathrm{H})^{32}$ showing the 16-17 double bond, was obtained (21\%). Finally, compound 18 was reacted with $\mathrm{NaSCH}_{3}$ in $\mathrm{DMF}^{34}$ for $1 \mathrm{~h}$ when at this time the starting compound disappeared on monitoring the reaction progress by TLC. After work-up of the reaction mixture, the raw material was purified by Flash Chromatography giving three 
compounds, identified as 19a, b and c. Unfortunately, the desired compound 19a was present in lesser amount (25\%), 19b (37,5\%) and 19c (37\%). The different reactivity of benzoyl compound 18 in comparison with compound 6 (schemes 1 and 2) towards $\mathrm{NaSCH}_{3}$ has not been understood. In this case, the F-C acylation reaction of 3-methoxy-estrone, as for some reported alkylation ${ }^{35}$ other than with adamanthanol, was proved not to be a regio-specific reaction. Therefore, it is possible to conclude that the lack of region specificity of F-C acylation towards position 2 together with the low yields of compound 19a might represent a drawback for the future synthesis of novel 2substituted analogs.

Scheme 3. Synthesis of compound 19

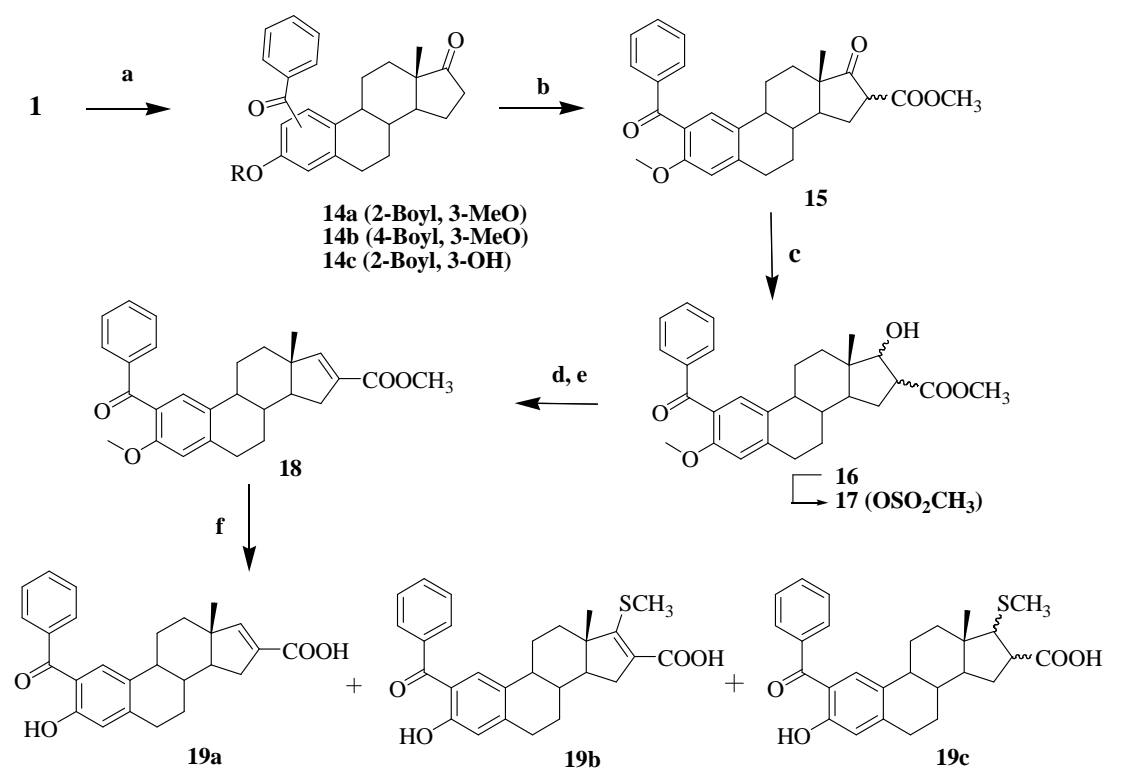

Reagents and conditions: a) benzoyl chloride, $\mathrm{AlCl}_{3}$, anhydrous DCM, 3h, 91\%; b) $\mathrm{C}_{3} \mathrm{H}_{6} \mathrm{O}_{3}, \mathrm{NaH}$, rif., $3 \mathrm{~h}, 31 \%$; c) $\mathrm{NaBH}_{4}, \mathrm{THF} / \mathrm{CH}_{3} \mathrm{OH}$ 9:1, 0.5 h, 94\%; d) $\mathrm{MsCl}, \mathrm{Et}_{3} \mathrm{~N}$, anhydrous $\mathrm{CH}_{2} \mathrm{Cl}_{2}$; e) DBU, $\mathrm{C}_{6} \mathrm{H}_{6}$, rif., 5h, 21\%; f) $\mathrm{NaSCH}_{3}$, DMF, 1 h., $63 \%$.

It is known that the Suzuki-Miyaura cross-coupling reaction ${ }^{36}$ is a robust method to obtain a variety of aromatic derivatives because of the large amount of commercially available boronic acids, therefore it was planned to study also the possibility to obtain novel 2-substituted analogs by this kind of cross-coupling. In scheme 4, the synthesis of three novel 2-substituted compounds by this method is reported.

Preliminary results suggested an optimal pathway where the starting estrone was protected as benzyl ether, easily removable later in the path, giving compound $20\left(\mathrm{BzCl}, \mathrm{Bu}_{4} \mathrm{NI}\right)(99 \%)^{28}$ that was then transformed into the 16-methoxycarbonylated derivative $\mathbf{2 1}$, as before $(81 \%) .{ }^{30}$ This was first selectively reduced with $\mathrm{NaBH}_{4}$ to the corresponding alcohol $22(68 \%){ }^{31}$ After mesylation of 
17-hydroxy (23) and the next treatment with DBU, compound 24 was obtained (54\%). In previous experiments it was seen that as for 3-methoxy compound 12, also the 2-benzyloxy derivative $\mathbf{2 4}$ resulted not to be a suitable intermediate for iodination step. Thus, compound 22 was catalytically reduced $\left(\mathrm{Pd} / \mathrm{C} 10 \%, \mathrm{H}_{2}\right)^{37}$ producing the 2,17-dihydroxylic derivative $\mathbf{2 5}(93 \%)$ that was submitted to the successful iodination to compound 26 with $\mathrm{NIS},\left(\mathrm{CF}_{3} \mathrm{SO}_{3}\right)_{3} \mathrm{In}$ in $\mathrm{CH}_{3} \mathrm{CN}$ for $8 \mathrm{~h}^{38}$ Bromination had previously been carried out on 3-methoxy-estrone 1 (scheme 1) but it was slightly region-selective (data not shown) and mainly with the 2-Br-derivatives the cross-coupling did not take place later in the synthesis. The iodination of compound 25 with NIS yielded the desired 2iodinated product $26(51 \%)$ and a little amount of 4-iodinated and 2,4-diiodinated as deduced from ${ }^{1} \mathrm{H}$ NMR spectrum of the reaction mixture. Therefore, iodinating with NIS and $\left(\mathrm{CF}_{3} \mathrm{SO}_{3}\right)_{3}$ In proved to be more region-selective compared with the other methods carried out (data not shown). It is worth to underline that the chromatographic purification of $\mathbf{2 6}$ in presence of other two iodinated compounds was only feasible when the two phenolic and alcoholic hydroxyls were free. Unfortunately, for compound 26 16-17 double bond formation was no longer possible. Preliminarily, the S-M cross-coupling reaction of compound 26 was accomplished with three boronic acids of different hindrance and following two different methods: conventional synthesis ${ }^{38}$ and MW added organic synthesis. ${ }^{39}$ The first one provided only complex mixtures, while the second one was found to be successful due to the following advantages: shorter reaction times, higher yields, less by-products and thus easier to process mixtures. After flash chromatography purification, compounds $\mathbf{2 7 - 2 9}$ were obtained in good yields $26 \%$, 33\%, 42\%, respectively.

Finally, the three methyl esters 27-29 were transformed into the corresponding acids by treatment with $\mathrm{MeOH}-\mathrm{NaOH} 10 \%$ giving the compounds $30(99 \%), 31(98 \%)$ and $32(97 \%) .{ }^{40}$ For all the synthesized compounds, complete characterization was carried out by mono-dimensional ${ }^{1} \mathrm{H}-{ }^{13} \mathrm{C}$ and bi-dimensional HSQC, HMBC and COSY NMR experiments. 
Scheme 4. Synthesis of compounds 30-32
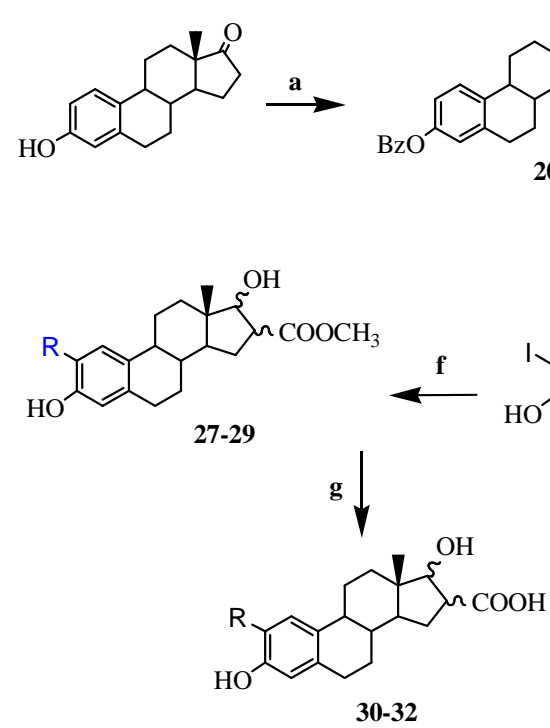

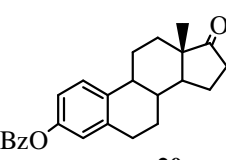

20

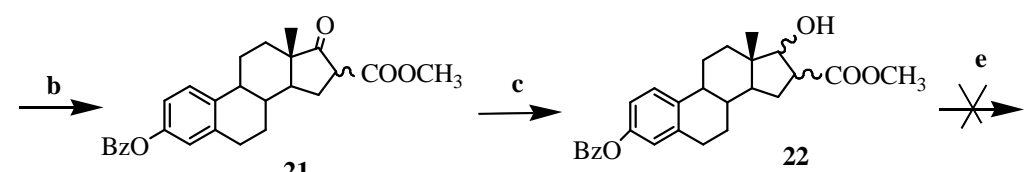

d
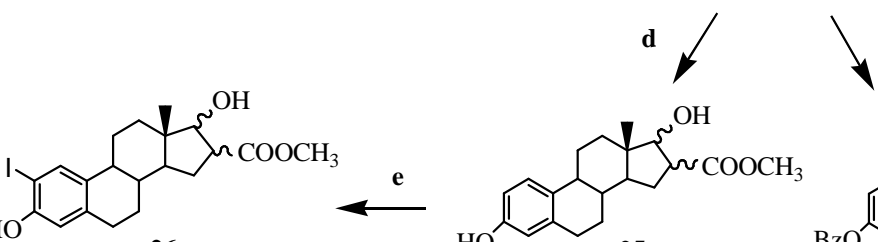

26<smiles>COC(=O)[C@H]1C[C@H]2[C@@H]3CCc4cc(O)ccc4[C@H]3CC[C@]2(C)[C@H]1O</smiles>

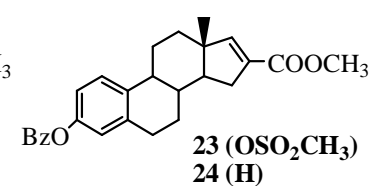
$24\left(\mathrm{OSO}_{2} \mathrm{CH}_{3}\right)$
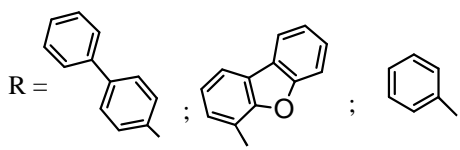

$27,30 \quad 28,31 \quad 29,32$

Reagents and conditions: a) $\mathrm{BzCl}, \mathrm{Bu}_{4} \mathrm{~N}^{+} \mathrm{I}, \mathrm{CH}_{2} \mathrm{Cl}_{2}, \mathrm{NaOH} 10 \%$, rif., 3h, 99\%; b) $\mathrm{C}_{3} \mathrm{H}_{6} \mathrm{O}_{3}, \mathrm{NaH}$, rif., 3h, 31\%; c) $\mathrm{NaBH}_{4}, \mathrm{THF} / \mathrm{CH}_{3} \mathrm{OH}$ 9:1, 1h, 68\%; d) Pd/C, $\mathrm{H}_{2}$, EtOAc, r.t., 8h, 93\%; e) NIS, $\left(\mathrm{CF}_{3} \mathrm{SO}_{3}\right)_{3} \mathrm{In}, \mathrm{CH}_{3} \mathrm{CN}, 8 \mathrm{~h}, 51 \%$; f) 1. $\mathrm{C}_{12} \mathrm{H}_{11} \mathrm{BO}_{2}, \mathrm{Pd}\left(\mathrm{PPh}_{3}\right)_{4}, \mathrm{~K}_{2} \mathrm{CO}_{3}, \mathrm{C}_{4} \mathrm{H}_{8} \mathrm{O}_{2}, \mathrm{MW}\left(160^{\circ} \mathrm{C}\right), 30 \mathrm{~min}, 33 \%$; 2. $\mathrm{Pd}\left(\mathrm{PPh}_{3}\right)_{4}, \mathrm{~K}_{2} \mathrm{CO}_{3}, \mathrm{C}_{4} \mathrm{H}_{8} \mathrm{O}_{2}, \mathrm{MW}\left(160^{\circ} \mathrm{C}\right), 30$ min, 42\%; 3. $\mathrm{C}_{6} \mathrm{H}_{7} \mathrm{BO}_{2}, \mathrm{Pd}\left(\mathrm{PPh}_{3}\right)_{4}, \mathrm{~K}_{2} \mathrm{CO}_{3}, \mathrm{C}_{4} \mathrm{H}_{8} \mathrm{O}_{2}$, $\mathrm{MW}\left(160^{\circ} \mathrm{C}\right), 30 \mathrm{~min}, 26 \%$; g) MeOH, $\mathrm{NaOH} 10 \%$, rif, 1h, $99 \%$.

Furthermore, it is noted that the synthesis described in scheme 4, despite the successful S-M crosscoupling on the iodinated $\mathbf{2 6}$, presents a strong restriction due to the impracticality to obtain the designed compounds with 16-17 double bond. Indeed, iodination reaction with NIS didn't work with compounds 12 and 24 and additionally the chromatographic purification of the 2-iodinated derivative was achievable only with the di-hydroxylic compound $\mathbf{2 6}$ that however was not suitable for the removal of 17 -alcoholic $\mathrm{OH}$ by the method reported before.

\subsection{Biology}

\subsubsection{Effect of compounds 7, 8, 19a, 30-32 on cell viability.}

In order to verify whether the synthetic ROR $\gamma t$ inverse agonists had any effect on cell growth and survival, MTT assay was performed on HepG2 cells. As shown in Figure 6, compound 19a was found to be toxic at the highest concentrations tested $(25 \mu \mathrm{M}, \mathrm{p}<0.01 v s$ vehicle; $50 \mu \mathrm{M}, \mathrm{p}<0.001 v s$ vehicle), whereas compounds $\mathbf{3 0}$ and $\mathbf{3 2}$ caused a significant decrease of cell viability even at lower concentrations. No cytotoxic effects were observed on after incubation of HepG2 cells with compounds $\mathbf{7 , 8}$ and $\mathbf{3 1}$. 

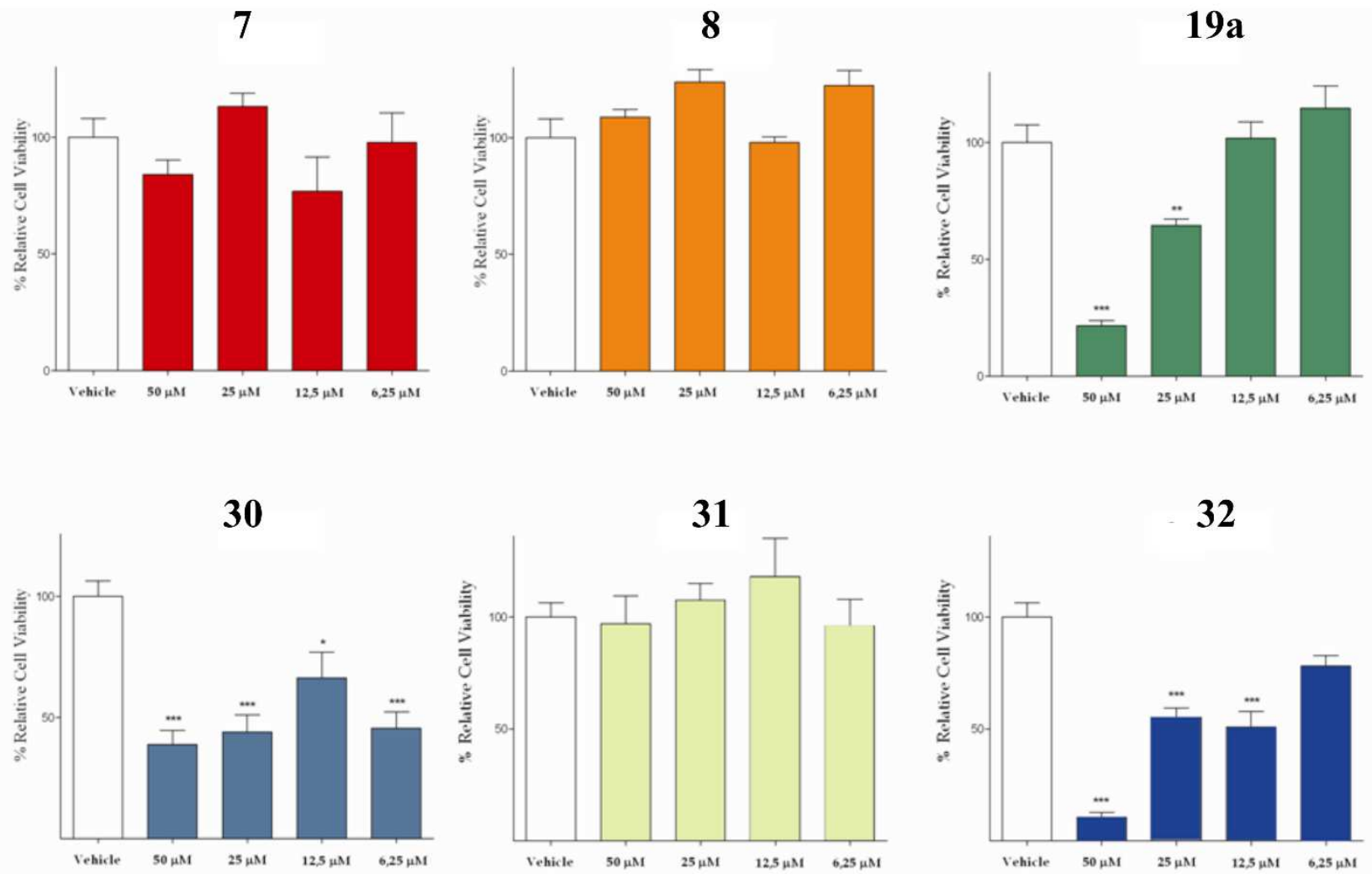

Figure 6. Cell viability assay on HepG2 cells treated with the synthetic compounds 7, 8, 19a and 30-32, reported as percentage of viable cells with respect to control treated with medium. Results are mean \pm SEM. $* \mathrm{p}<0.05, * * \mathrm{p}<0.01$ and $* * * \mathrm{p}<0.001$ vs vehicle, one-way ANOVA followed by Dunnett post hoc test. Three independent experiments were performed in quadruplicate. 
Table 2. Structure of compounds tested for cytotoxic and estrogenic activity

\begin{tabular}{|c|c|c|c|}
\hline Compound & Structure & Formula & MW \\
\hline 7 & & $\mathrm{C}_{30} \mathrm{H}_{38} \mathrm{O}_{3}$ & 446.62 \\
\hline 8 & & $\mathrm{C}_{29} \mathrm{H}_{36} \mathrm{O}_{3}$ & 432.27 \\
\hline $19 a$ & & $\mathrm{C}_{26} \mathrm{H}_{26} \mathrm{O}_{4}$ & 402.18 \\
\hline 30 & & $\mathrm{C}_{31} \mathrm{H}_{32} \mathrm{O}_{4}$ & 468.59 \\
\hline 31 & & $\mathrm{C}_{31} \mathrm{H}_{30} \mathrm{O}_{5}$ & 482.57 \\
\hline 32 & & $\mathrm{C}_{25} \mathrm{H}_{28} \mathrm{O}_{4}$ & 392.49 \\
\hline
\end{tabular}

\subsubsection{Estrogenic activity of the synthetic compounds 7, 8, 19a and 30-32.}

Estrogenic activity of the novel steroidal compounds 7, 8, 19a and 30-32 was evaluated because of the molecular structure being derived from estrone, a known estrogenic agent. Real time PCR analysis was performed on RNA extracts from an estrogen-receptors (ERs) expressing cell line (MCF-7). Cells were treated with the compounds in order to test whether the expression of GREB1 and CXCL12, two target genes for ERs, was altered. Figure 7 shows that the expression of both GREB1 and CXCL12 was increased by compound 8 ( $p<0.05$ and $p<0.001$ for GREB and CXCL12 mRNA expression $v s$ vehicle, respectively), 30 ( $\mathrm{p}<0.001$ for GREB and CXCL12 mRNA expression $v s$ vehicle), 31 ( $\mathrm{p}<0.001$ for GREB and CXCL12 mRNA expression $v s$ vehicle) and 32 
( $\mathrm{p}<0.001$ and $\mathrm{p}<0.05$ for GREB and CXCL12 mRNA expression $v s$ vehicle, respectively), while neither compound 7 nor 19a display any estrogenic activity.

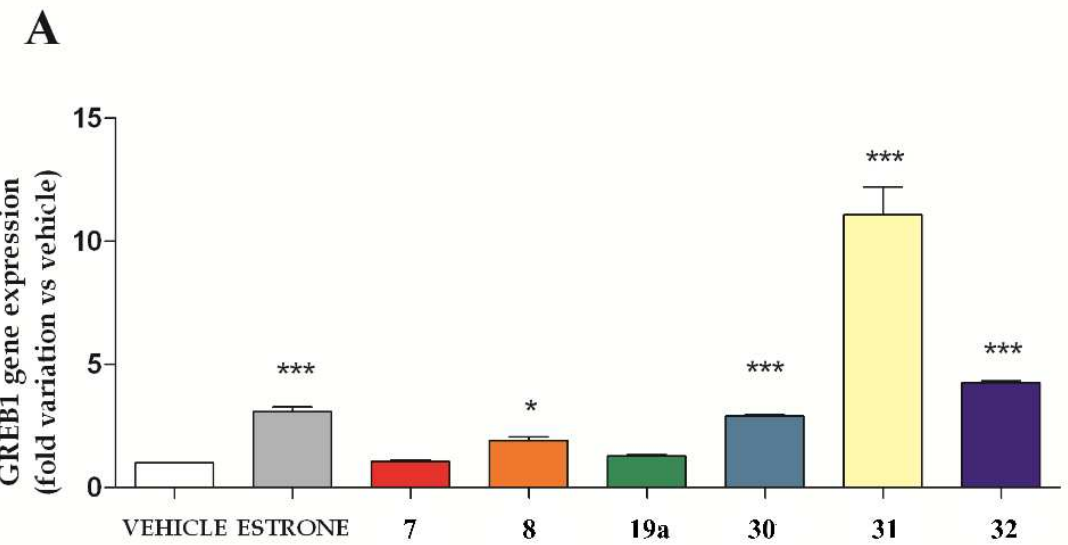

B

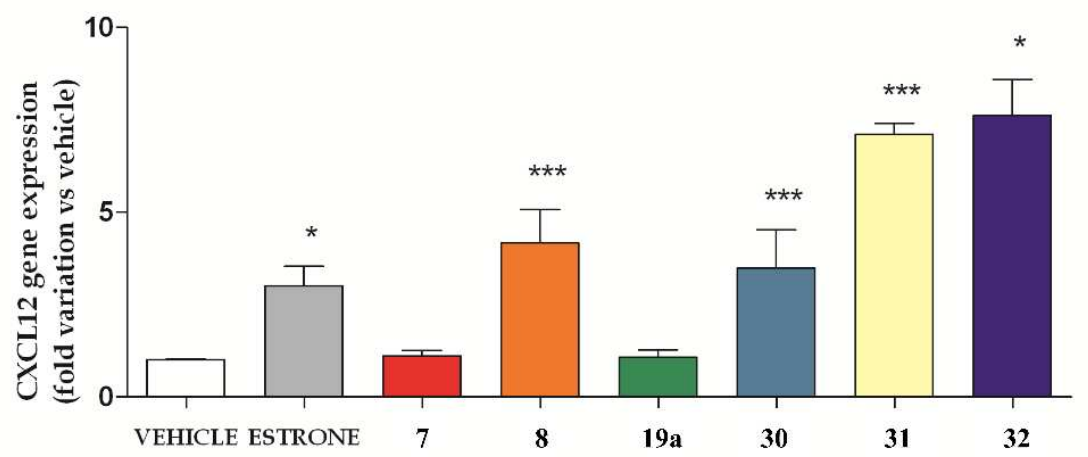

Figure 7. Gene expression of GREB1 (A) and CXCL12 (B) in MCF-7 cells treated with the synthetic compounds 7, 8, 19a and 30-32. All the compounds were tested at $2 \mu \mathrm{M}$ concentration. Results are mean \pm SEM. $* \mathrm{p}<0.05$ and $* * *$ $\mathrm{p}<0.001$ vs vehicle, one-way ANOVA followed by Dunnett post hoc test. Three independent experiments were performed in triplicate.

\subsubsection{Evaluation of inverse-agonist activity of compounds 7, 8, 19a and 31 on ROR $\gamma \mathrm{t}$}

Based on the MTT assay results, where compounds 7, 8 and $\mathbf{3 1}$ did not display any cytotoxic activity, and compound 19a was cytotoxic only at the highest concentrations $(25-50 \mu \mathrm{M})$, compounds 7, 8, 19a and 31 were selected for evaluating their ability to modulate the in vitro ROR $\gamma t$ activity in a cellular environment by means of a Gal UAS-Luc cotransfection system taken ursolic acid as reference compound. Since the absence of in vitro cytotoxicity at low concentrations is a promising feature for candidate drugs designed for lifetime lasting diseases such as autoimmune 
diseases, no further in vitro characterization of $\mathbf{3 0}$ and $\mathbf{3 2}$ was performed. To ascertain whether HEK-293 cells had been successfully transfected with the plasmids, ROR $\gamma t$ protein expression was evaluated by means of Western Blot analysis. As shown in Figure 8, the cells transfected with all three plasmids (ROR $\gamma$-Gal4, UAS-Luc, NanoGlo) express ROR $\gamma$ t, whereas the cells transfected with the plasmids UAS-Luc and NanoGlo do not express the protein containing the ROR $\gamma \mathrm{t}$ LBD. Densitometric analysis confirmed that ROR $\gamma t$ is not expressed in lanes 2 and 3 (Data not shown).

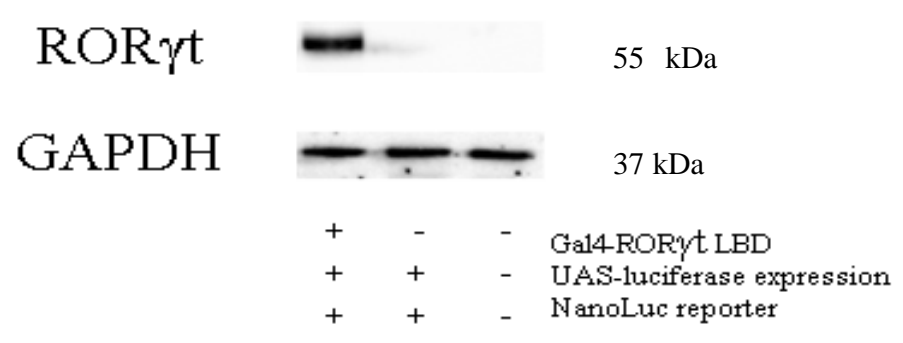

Figura 8. Western blot analysis of ROR $\gamma \mathrm{t}(58 \mathrm{kDa})$ protein in whole protein extracts of HEK-293 cells transfected with Gal4-RORg LBD plasmid, UAS-luc and NanoLuc reporter plasmid (+) or not-transfected cells (-). GAPDH (43 KDa) was used as loading control.

Figure 9 shows the ability of the tested compounds to decrease activity, as luminescence lessening, at various concentrations. After $2 \mu \mathrm{M}$ treatment only compound 19a displayed a slight but significant activity, at $5 \mu \mathrm{M}$ both compounds 8 and 19a decreased activity in a significant amount, at $10 \mu \mathrm{M}$ a dramatic decrease in ROR $\gamma$ activity could be observed after addition for all the tested compounds ( $\mathrm{p}<0.001)$, and finally, at $20 \mu \mathrm{M}$ all compounds showed an inhibitory effect comparable to that of ursolic acid. Fig. 9 shows that compounds 7, 8, 19a and 31 displayed a concentrationdependent activity. Extrapolated IC50 values were similar for compounds 19a and 31 (4,4 $\mu \mathrm{M}$ and 4,7 $\mu \mathrm{M}$, respectively), and increased for compounds 7 and $\mathbf{8}(6,8$ and 6,5 $\mu \mathrm{M}$, respectively). The most relevant outcome of the in vitro ROR $\gamma t$ inhibitory activity by the selected compounds was that compound 19a significantly reduced ROR $\gamma$ t activity at low concentrations $(2-5 \mu \mathrm{M}, \mathrm{p}<0.05$ vs vehicle). 
A

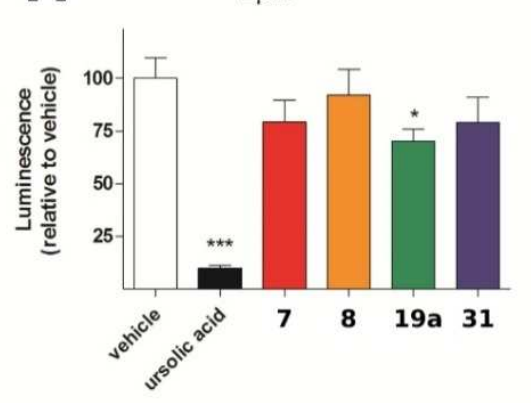

$10 \mu \mathrm{M}$

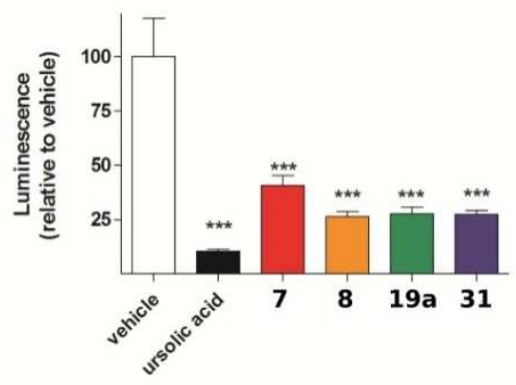

B

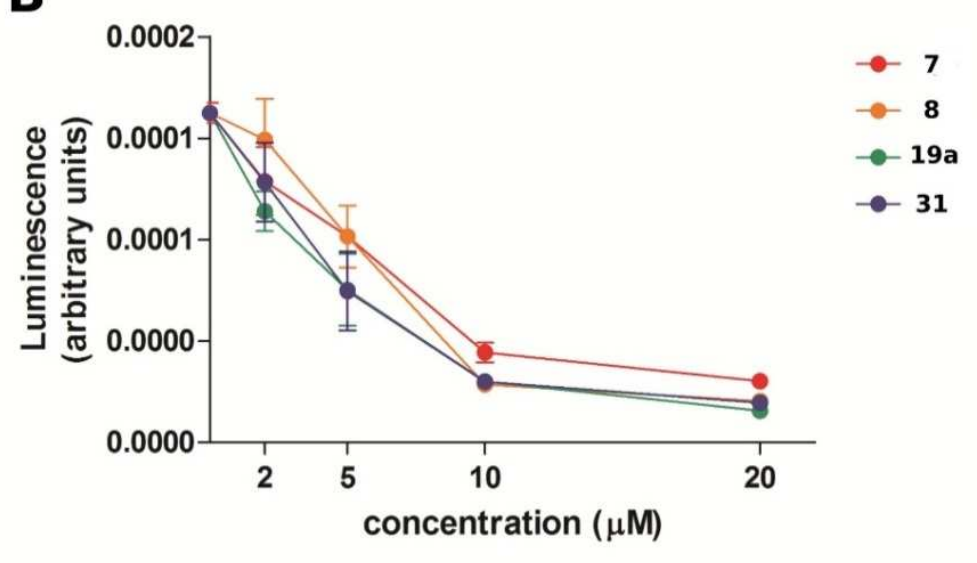

Figure 9. Evaluation of inverse-agonist activity of compounds 7, 8, 19a and 31 on ROR $\gamma \mathrm{t}(\mathrm{A})$ and dose-dependent efficacy (B). Results are mean Â \pm SEM. * $\mathrm{p}<0.05$ and $* * * \mathrm{p}<0.001$ vs vehicle, one-way ANOVA followed by Dunnett post hoc test. Three independent experiments were performed in triplicate.

\subsubsection{Effect of compounds 7, 8, 19a and 31 on cell cycle distribution}

In order to complete the characterization of the selected synthetic compounds, we analysed their effect on cell cycle distribution both in HepG2 and HEK-293 cells. Fig. 10 shows the effect of compounds 7, 8, 19a and 31 on both cell viability of HepG2 and HEK-293 either transfected or not with ROR $\gamma$ t- Gal4 plasmid, and cell cycle distribution. After confirming the absence of cytotoxicity 
of the selected synthetic compounds on both cell lines, we also demonstrated that cell cycle distribution was not affected even after incubation with the highest concentrations $(10$ and $20 \mu \mathrm{M})$ tested previously (see Section 2.3.3).
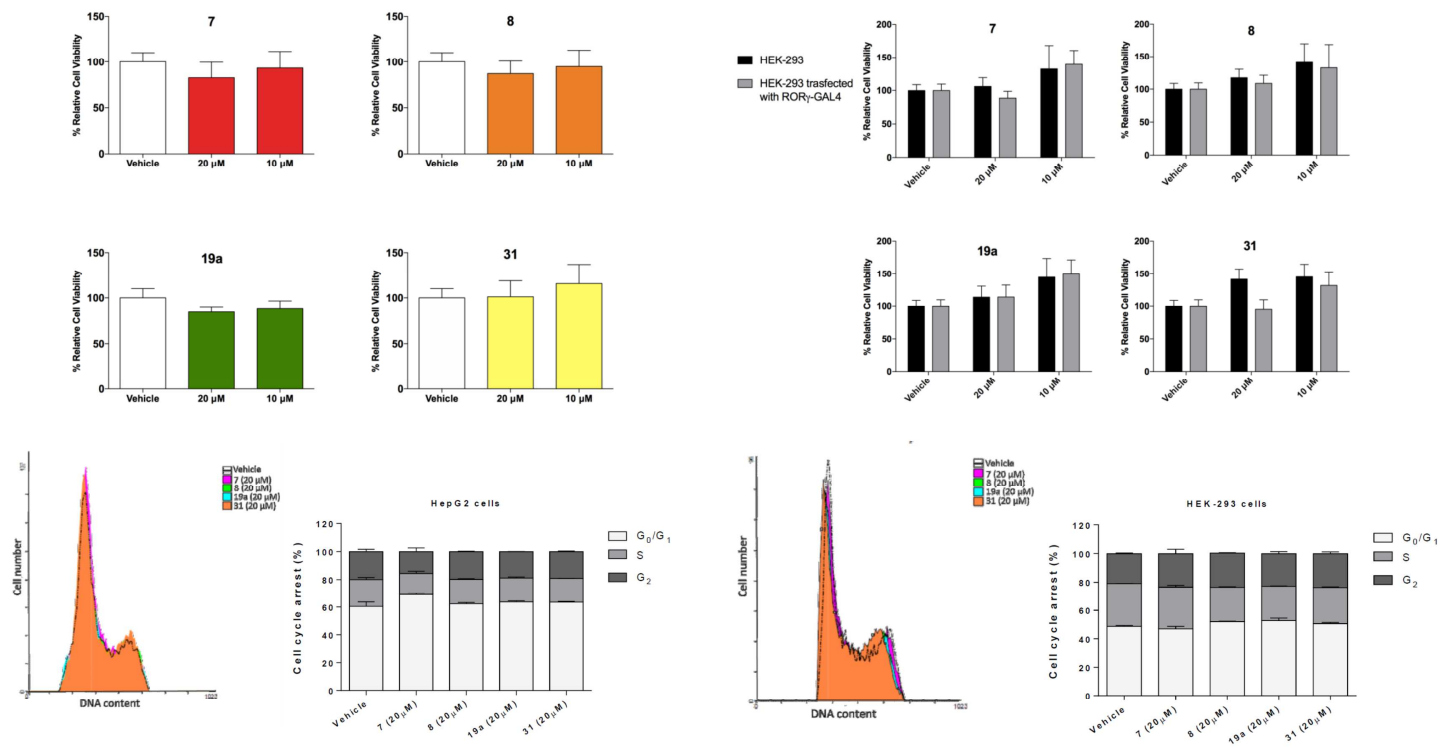

Fig. 10. Cell viability of HepG2 (left) and HEK-293 (right) cells after incubation with compounds 7, 8, 19a and 31 at 10 and $20 \mu \mathrm{M}$. Below, cell cycle distribution analysis at $20 \mu \mathrm{M}$. The results are expressed as mean $\pm \mathrm{SEM}$. Three independent experiments were performed in duplicate.

\subsection{Docking study of compound 19a}

Compound 19a was docked using the crystal structure of ROR $\gamma t$ in complex with digoxin (PDB code 3B0W). ${ }^{27}$ Computer docking simulation of 19a was performed using Maestro 10.5 Glide software SP precision. The most favoured pose of 19a (Figure 11) in the presumptive binding site is similar to the one found for 8 (Figure 5). Compound 19a could be readily accommodated in the pocket, but also in this case, no significant interactions with residues responsible for digoxin binding were found. ${ }^{15}$ Again, we can suggest the possibility that the substituent in position 2 (benzoyl group in this case), could perturb the interactions necessary for ROR $\gamma$ t activity. ${ }^{15,17}$ 


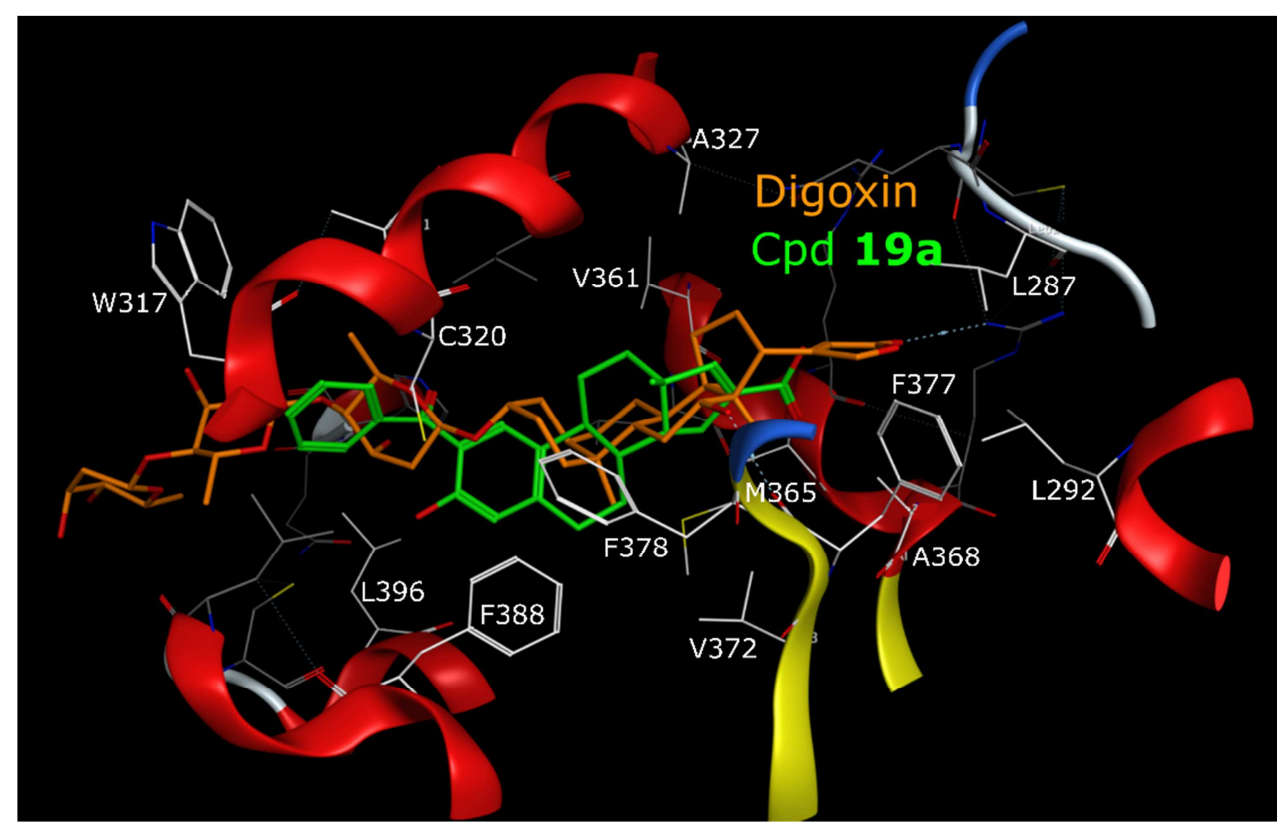

Figure 11. Comparison of the crystallographic structure of digoxin (in orange) in complex with ROR $\gamma$ t ligand binding domain (Protein Data Bank code 3B0W) and the energetically most favourable pose of 19a (in green) obtained by molecular docking simulation. Hydrophobic residues are shown in white. Hydrogen atoms are omitted.

\section{Conclusion}

Looking the NRs natural ligands structure through, representative arotenoids ligands and RORs ligands, by means of a structure-based approach founded on hybridization of chemical structures, a lead compound 8 (MG 2778) was identified, synthesized and chemically modified in order to obtain a small series of novel steroidal compounds acting as ROR $\gamma$ inverse agonists. Docking simulations of compounds 8 and 19a into ROR $\gamma$ t LBD in complex with digoxin showed a potential binding affinity.

The four non-cytotoxic compounds 7, 8, 19a and 31 were tested by means of a Gal UAS-Luc cotransfection system taken ursolic acid as reference compound, resulting to act as ROR $\gamma t$ inverse agonists in a dose dependent manner. Considering these preliminary biological results, we can propose that using the tetracycle scaffold is an appropriate approach for the further design of ROR $\gamma t$ inverse agonists. Regarding the bound groups at 2, 3 and 16 positions, we can deduce that a bulky alkyl or aryl group in the 2 position is necessary in order to reduce estrogenic activity, although low estrogenic activity is maintained in presence of the free 3-phenolic $\mathrm{OH}$ as for compound $\mathbf{8}$ with respect to compound $7\left(3-\mathrm{OCH}_{3}\right)$. However, no estrogenic activity was observed for compound 19a having the free 3-OH. In this case, we suggest the existence of a H-bond, between the carbonyl of the flexible benzoylic group and the phenolic $\mathrm{OH}$. Probably, this event could hamper the interaction 
of the $\mathrm{OH}$ itself at the ER, however, at the docking simulation of 19a in ROR $\gamma \mathrm{t}$ LBD (Figure 10) we didn't see it. The polar terminus $(16-\mathrm{COOH})$ is essential for activity while the 16-17 double bond not as noted for compound $\mathbf{3 1}$ that was active as well as compounds showing the double bond at that position. The potency of our compounds is lower than that of ursolic acid, the strongest known ROR $\gamma t$ inverse agonist, but their efficacy is similar. In particular, compound 19a was the most active, causing a significant reduction of ROR $\gamma$ t activity at low micromolar concentrations. From the above considerations, we can conclude that 19a may represent a good candidate for further in vitro and in vivo characterization and may serve as a useful tool for developing ROR $\gamma$ t inverse agonists.

\section{Experimental section}

Melting points were determined on a Buchi M-560 capillary melting point apparatus and are uncorrected. ${ }^{1} \mathrm{H}$ NMR spectra were determined on Bruker 300 and $400 \mathrm{MHz}$ spectrometers, with the solvents indicated; chemical shifts are reported in $\delta(\mathrm{ppm})$ downfield from tetramethylsilane as internal reference. Coupling constants are given in hertz. In the case of multiplets, chemical shifts were measured starting from the approximate centre. Integrals were satisfactorily in line with those expected based on compound structure. Mass spectra were obtained on a Mat 112 Varian Mat Bremen $(70 \mathrm{eV})$ mass spectrometer and Applied Biosystems Mariner System 5220 LC/MS (nozzle potential $140 \mathrm{eV}$ ). Column flash chromatography was performed on Merck silica gel (250-400 mesh ASTM); chemical reactions were monitored by analytical thin-layer chromatography (TLC) on Merck silica gel 60 F-254 glass plates. Microwave assisted reactions were performed on a CEM Discover ${ }^{\circledR}$ monomode reactor with a built-in infrared sensor assisted-temperature monitoring and automatic power control; all reactions were performed in closed devices under pressure control. Solutions were concentrated on a rotary evaporator under reduced pressure. The purity of new tested compounds was checked by HPLC using the instrument HPLC VARIAN ProStar model 210, with detector DAD VARIAN ProStar 335. The analysis was performed with a flow of $1 \mathrm{~mL} / \mathrm{min}$, a C-8 column of dimensions $250 \mathrm{~mm}$ X $4.6 \mathrm{~mm}$, a particle size of $5 \mathrm{~mm}$, and a loop of $10 \mathrm{~mL}$. The detector was set at $254 \mathrm{~nm}$. The mobile phase consisted of phase A (Milli-Q $\mathrm{H}_{2} \mathrm{O}, 18.0 \mathrm{MU}$, TFA $0.05 \%)$ and phase $\mathrm{B}(95 \% \mathrm{MeCN}, 5 \%$ phase $\mathrm{A})$. Gradient elution was performed as reported: $0 \mathrm{~min}$, \% B 1/4 10; 0e20 min, \% B 1/4 90; $25 \mathrm{~min}, \%$ B 1/4 90; $26 \mathrm{~min}, \%$ B 1/4 10; $31 \mathrm{~min}, \%$ B 1/4 10.

Starting materials were purchased from Sigma-Aldrich and Alfa Aesar, and solvents were from Carlo Erba, Fluka and Lab-Scan. DMSO was obtained anhydrous by distillation under vacuum and stored on molecular sieves. 
Dulbecco's modified Eagle's medium (DMEM), was obtained from Sigma-Aldrich Italy (Milan, Italy). Dulbecco's modified Eagle's medium (DMEM), was obtained from Sigma-Aldrich Italy (Milan, Italy). Foetal bovine serum (FBS), glutamine and penicillin-streptomycin (pen-strep) solutions were obtained from Gibco (Life Technologies Italia, Monza, Italy).

\subsection{Synthesis}

4.1.1 General procedure for the synthesis of of-protected estrone derivatives 1 and 20. As a typical procedure, the synthesis of the-3-methoxy-estrone derivative is described in detail. A mixture of commercial estrone $(1.00 \mathrm{~g}, 3.70 \mathrm{mmol})$ and tetrabutylammonium iodide $(0.068 \mathrm{~g}, 0.185 \mathrm{mmol})$ was suspended in $\mathrm{CH}_{2} \mathrm{Cl}_{2}(18 \mathrm{~mL})$. Methyl iodide $(0.875 \mathrm{~mL}, 14.06 \mathrm{mmol})$ and a $10 \% \mathrm{NaOH}$ solution $(18 \mathrm{~mL})$ were added. The mixture was refluxed at $70^{\circ} \mathrm{C}$ for $3 \mathrm{~h}$. The reaction was monitored by TLC analysis (eluent chloroform/methanol 95:5). At the end of the reaction, the two phases were clearly transparent and were separated. The aqueous phase was extracted with $\mathrm{CH}_{2} \mathrm{Cl}_{2}$ (30 mLx3) and the combined organic phases were washed with brine, dried over sodium sulphate, filtered and evaporated under vacuum to give a white solid product (1.045 $\mathrm{g})$.

\section{(8R,9S,13S,14S)-7,8,9,11,12,13,15,16-octahydro-3-methoxy-13-methyl-6H-}

cyclopenta[a]phenanthren-17(14H)-one (1). Yield 99\%; $\mathrm{R}_{f}=0.88$ (chloroform/methanol, 95:5); $\mathrm{mp}=177-178^{\circ} \mathrm{C} ;{ }^{1} \mathrm{H} \mathrm{NMR}\left(300 \mathrm{MHz}, \mathrm{CDCl}_{3}\right): \delta 0.84(\mathrm{~s}, 3 \mathrm{H}), 1.49(\mathrm{~m}, 1 \mathrm{H}), 1.50(\mathrm{~m}, 1 \mathrm{H}), 1.52(\mathrm{~m}$, 1H), $1.53(\mathrm{~m}, 1 \mathrm{H}), 1.61(\mathrm{~m}, 1 \mathrm{H}), 1.65(\mathrm{~m}, 1 \mathrm{H}), 1.97(\mathrm{~m}, 1 \mathrm{H}), 2.05(\mathrm{~m}, 1 \mathrm{H}), 2.09(\mathrm{~m}, 1 \mathrm{H}), 2.27(\mathrm{~m}$, 1H), $2.42(\mathrm{~m}, 1 \mathrm{H}), 2.51(\mathrm{~m}, 1 \mathrm{H}), 2.53(\mathrm{~m}, 1 \mathrm{H}), 2.93(\mathrm{~m}, 2 \mathrm{H}), 3.80(\mathrm{~s}, 3 \mathrm{H}), 6.67(\mathrm{~d}, J=2.73 \mathrm{~Hz}$, $1 \mathrm{H}), 6.75(\mathrm{dd}, J=8.61 \mathrm{~Hz}, J=2.73 \mathrm{~Hz}, 1 \mathrm{H}), 7.23 \mathrm{ppm}(\mathrm{d}, J=8.61 \mathrm{~Hz}, 1 \mathrm{H}) ;{ }^{13} \mathrm{C}$ NMR $(75 \mathrm{MHz}$, $\left.\mathrm{CDCl}_{3}\right): \delta 13.86,21.60,25.94,26.57,29.68,31.60,35.88,38.39,43.99,48.03,50.43,55.22$, 111.59, 113.89, 126.35, 132.03, 137.77, 157.91, 220.94 ppm. HRMS (ESI-MS, 140 eV): m/z [M + $\left.\mathrm{H}^{+}\right]$calculated for $\mathrm{C}_{19} \mathrm{H}_{25} \mathrm{O}_{2}{ }^{+}$, 285.1855; found, 285.1865 .

\section{(8R,9S,13S,14S)-3-(benzyloxy)-7,8,9,11,12,13,15,16-octahydro-13-methyl-6H-}

cyclopenta[a]phenanthren-17(14H)-one (20). Compound 20 was prepared as for compound 1 by reacting estrone $(2.50 \mathrm{~g}, 9.25 \mathrm{mmol})$, tetrabutylammonium iodide $(0.178 \mathrm{~g}, 0.462 \mathrm{mmol})$, benzyl bromide (4.18 mL, $35.14 \mathrm{mmol})$ in a mixture of $\mathrm{CH}_{2} \mathrm{Cl}_{2} / 10 \% \mathrm{NaOH}$ solution (45 mL each). After the workup, the obtained residue was washed with hexane to remove excess benzyl bromide yielding $3.301 \mathrm{~g}$ of yellow solid. Yield 99\%; $\mathrm{R}_{f}=0.38$ ( $\mathrm{n}$-hexane/ethyl acetate, 8:2); $\mathrm{mp}=128$ $129^{\circ} \mathrm{C} ;{ }^{1} \mathrm{H}$ NMR (400 MHz, $\left.\mathrm{CDCl}_{3}\right)$ : $0.91 \mathrm{ppm}(\mathrm{s}, 3 \mathrm{H}), 1.50(\mathrm{~m}, 1 \mathrm{H}), 1.52(\mathrm{~m}, 1 \mathrm{H}), 1.53(\mathrm{~m}, 1 \mathrm{H})$, $1.56(\mathrm{~m}, 1 \mathrm{H}), 1.62(\mathrm{~m}, 1 \mathrm{H}), 1.65(\mathrm{~m}, 1 \mathrm{H}), 1.99(\mathrm{~m}, 1 \mathrm{H}), \delta 2.04(\mathrm{~m}, 1 \mathrm{H}), 2.09(\mathrm{~m}, 1 \mathrm{H}), 2.17(\mathrm{~m}, 1 \mathrm{H})$, $2.29(\mathrm{~m}, 1 \mathrm{H}), 2.43(\mathrm{~m}, 1 \mathrm{H}), 2.51(\mathrm{~m}, 1 \mathrm{H}), 2.88(\mathrm{~m}, 2 \mathrm{H}), 5.04(\mathrm{~s}, 2 \mathrm{H}), 6.73(\mathrm{~d}, J=2.7 \mathrm{~Hz}, 1 \mathrm{H}), 6.79$ $(\mathrm{dd}, J=8.6,2.8 \mathrm{~Hz}, 1 \mathrm{H}), 7.20(\mathrm{~d}, J=8.4 \mathrm{~Hz}, 1 \mathrm{H}), 7.34-7.29(\mathrm{~m}, 1 \mathrm{H}), 7.40-7.35$ (m, 2H), $7.45-$ 
$7.41 \mathrm{ppm}(\mathrm{m}, 2 \mathrm{H}) ;{ }^{13} \mathrm{C} \mathrm{NMR}\left(101 \mathrm{MHz}, \mathrm{CDCl}_{3}\right): \delta$ 13.89, 21.62, 25.95, 26.58, 29.69, 31.63, 35.90, 38.40, 44.04, 48.04, 50.47, 70.00, 112.42, 114.94, 126.37, 127.45, 127.88, 128.57, 132.36, 137.29, 137.82, 156.90, 220.94 ppm. HRMS (ESI-MS, $140 \mathrm{eV}$ ): m/z $\left[\mathrm{M}+\mathrm{H}^{+}\right]$calculated for $\mathrm{C}_{25} \mathrm{H}_{29} \mathrm{O}_{2}{ }^{+}$, 361.2168; found, 361.2149 .

\subsection{2 (8R,9S,13S,14S)-7,8,9,11,12,13,15,16-octahydro-2-adamantyl-3-methoxy-13-methyl-6H-} cyclopenta[a]phenanthre ne-17(14H)-one (2). Into a two-necked $100 \mathrm{~mL}$ round-bottomed flask, compound 1 (1.08 g, $3.80 \mathrm{mmol})$ and 1-adamantanol $(0.70 \mathrm{~g}, 4.60 \mathrm{mmol})$ were placed and stirred for $15 \mathrm{~min}$ in hexane at $0^{\circ} \mathrm{C}$. Under $\mathrm{N}_{2}$ atmosphere, $\mathrm{BF}_{3} \mathrm{Et}_{2} \mathrm{O}(1.6 \mathrm{~mL}, 12.74 \mathrm{mmol})$ was added dropwise with a syringe. The mixture was stirred at room temperature for $4 \mathrm{~h}$. The reaction was monitored by TLC analysis (eluent cyclohexane/ethyl acetate, 8:2). At the end of the reaction, the mixture was transferred to a single-necked round-bottomed flask and the solvent was removed under vacuum. The obtained residue was treated with water to obtain a yellowish solid. The solid was filtrated and dried overnight under vacuum to yield $1.55 \mathrm{~g}$ of yellow powder. Yield $95 \% ; \mathrm{R}_{f}=$ 0.50 (cyclohexane/ethyl acetate, 8:2); $\mathrm{mp}=253^{\circ} \mathrm{C} ;{ }^{1} \mathrm{H}$ NMR $\left(400 \mathrm{MHz}, \mathrm{CDCl}_{3}\right): \delta 0.93(\mathrm{~s}, 3 \mathrm{H})$, $1.47(\mathrm{~m}, 1 \mathrm{H}), 1.53(\mathrm{~m}, 1 \mathrm{H}), 1.54(\mathrm{~m}, 1 \mathrm{H}), 1.56(\mathrm{~m}, 1 \mathrm{H}), 1.64(\mathrm{~m}, 1 \mathrm{H}), 1.65(\mathrm{~m}, 1 \mathrm{H}), 1.76(6 \mathrm{H}), 1.97$ (m, 1H), $2.01(\mathrm{~m}, 1 \mathrm{H}), 2.06(\mathrm{~m}, 1 \mathrm{H}), 2.11(3 \mathrm{H}), 2.20-2.08(6 \mathrm{H}), 2.30(\mathrm{~m}, 1 \mathrm{H}), 2.47(\mathrm{~m}, 1 \mathrm{H}), 2.53$ $(\mathrm{m}, 2 \mathrm{H}), 2.92(\mathrm{~m}, 2 \mathrm{H}), 3.83(\mathrm{~s}, 3 \mathrm{H}), 6.63(\mathrm{~s}, 1 \mathrm{H}), 7.18 \mathrm{ppm}(\mathrm{s}, 1 \mathrm{H}) ;{ }^{13} \mathrm{C} \mathrm{NMR}\left(101 \mathrm{MHz}, \mathrm{CDCl}_{3}\right): \delta$ 13.90, 21.61, 26.04, 26.63, 29.17, 29.30, 31.60, 35.92, 36.94, 37.16, 38.55, 40.79, 44.36, 48.08, 50.42, 55.03, 112.09, 123.68, 131.03, 134.72, 136.07, 156.87, 221.12 ppm. HRMS (ESI-MS, 140 $\mathrm{eV}): \mathrm{m} / \mathrm{z}\left[\mathrm{M}+\mathrm{H}^{+}\right]$calculated for $\mathrm{C}_{29} \mathrm{H}_{39} \mathrm{O}_{2}{ }^{+}, 419.2950$; found, 419.2932.

\subsection{3 (8R,9S,13S,14S)-7,8,9,11,12,13,15,16-octahydro-2-benzoyl-3-methoxy-13-methyl-6H-} cyclopenta $[a]$ phenanthre ne-17(14H)-one (14). In a dried round-bottomed flask, a suspension of anhydrous $\mathrm{AlCl}_{3}(1.260 \mathrm{~g}, 9.453 \mathrm{mmol})$ in $15 \mathrm{~mL}$ of anhydrous $\mathrm{CH}_{2} \mathrm{Cl}_{2}$ was prepared. The mixture was cooled to $0^{\circ} \mathrm{C}$ and benzoyl chloride $(0.880 \mathrm{~mL}, 7.574 \mathrm{mmol})$ was added dropwise. The mixture turned pink and was stirred for $1 \mathrm{~h}$ at room temperature. After this period, the mixture was cooled again at $0^{\circ} \mathrm{C}$ and then a solution of compound $\mathbf{1}(1.077 \mathrm{~g}, 3.787 \mathrm{mmol})$ in anhydrous $\mathrm{CH}_{2} \mathrm{Cl}_{2}(10$ $\mathrm{mL}$ ) was added dropwise. The reaction mixture turned yellow immediately and it was kept at $0^{\circ} \mathrm{C}$ for all the duration. The progression of the reaction was monitored by TLC analysis (hexane/ethyl acetate 6:4). At the end of the reaction, the suspension was poured into an ice/water mixture and it was acidified with concentrated $\mathrm{HCl}$. The two phases were separated: the aqueous phase was extracted with $\mathrm{CH}_{2} \mathrm{Cl}_{2}$ and the resulting organic phase was washed with saturated sodium bicarbonate solution, brine and dried over sodium sulphate. The mixture was filtered, and the solvent evaporated under vacuum to yield $1.344 \mathrm{~g}$ of white solid. Yield 58\% 14a, 31\% 14b, 2\%; 
14c; $\mathrm{R}_{f}=0.49$ (hexane/ethyl acetate, 6:4); $\mathrm{mp}=229^{\circ} \mathrm{C} ;{ }^{1} \mathrm{H} \mathrm{NMR}\left(300 \mathrm{MHz}, \mathrm{CDCl}_{3}\right): \delta 0.91$ (s, $3 \mathrm{H}), 1.45(\mathrm{~m}, 1 \mathrm{H}), 1.49(\mathrm{~m}, 1 \mathrm{H}), 1.50(\mathrm{~m}, 1 \mathrm{H}), 1.55(\mathrm{~m}, 1 \mathrm{H}), 1.59(\mathrm{~m}, 1 \mathrm{H}), 1.60(\mathrm{~m}, 1 \mathrm{H}), 1.92(\mathrm{~m}$, 1H), $2.05(\mathrm{~m}, 1 \mathrm{H}), 2.05(\mathrm{~m}, 1 \mathrm{H}), 2.06(\mathrm{~m}, 1 \mathrm{H}), 2.25(\mathrm{~m}, 1 \mathrm{H}), 2.32(\mathrm{~m}, 1 \mathrm{H}), 2.51(\mathrm{~m}, 1 \mathrm{H}), 2.97(\mathrm{~m}$, 2H), $3.68(\mathrm{~s}, 3 \mathrm{H}), 6.70(\mathrm{~s}, 1 \mathrm{H}), 7.30(\mathrm{~s}, 1 \mathrm{H}), 7.39-7.46(\mathrm{~m}, 2 \mathrm{H}) ; 7.50-7.57$ (m, 1H), $7.81 \mathrm{ppm}(\mathrm{dd}, J$ $=8.3,1.3 \mathrm{~Hz}, 2 \mathrm{H}) ;{ }^{13} \mathrm{C} \mathrm{NMR}\left(400 \mathrm{MHz}, \mathrm{CDCl}_{3}\right): \delta 13.83,21.56,25.77,26.40,29.94,31.45,35.81$, 38.26, 43.80, 47.94, 50.35, 55.64, 111.79, 126.47, 127.07, 128.08, 129.77, 131.98, 132.64, 138.20, 140.97, 155.54, 196.47, $220.60 \mathrm{ppm}$. HRMS (ESI-MS, $140 \mathrm{eV}): \mathrm{m} / \mathrm{z}\left[\mathrm{M}+\mathrm{H}^{+}\right]$calculated for $\mathrm{C}_{26} \mathrm{H}_{29} \mathrm{O}_{3}{ }^{+}, 389.2117$; found, 389.2212.

4.1.4 General procedure for the synthesis of derivatives $(\mathbf{3 , 9 , 1 5 , 2 1 )}$. As a typical procedure, the synthesis of the methyl 2-adamantyl-3-methoxy-16-carboxylate estrone derivative 3 is described in detail. Compound 2 (0.640 g, $1.53 \mathrm{mmol})$ was suspended in dimethyl carbonate $(11.2 \mathrm{~mL}, 132.91$ mmol) and $\mathrm{NaH}(0.320 \mathrm{~g}, 13.33 \mathrm{mmol})$ was added. A catalytic amount of $\mathrm{CH}_{3} \mathrm{OH}$ was added. The mixture was refluxed for $3 \mathrm{~h}$ at controlled temperature $\left(85^{\circ} \mathrm{C}\right)$. The reaction was monitored by TLC analysis (eluent cyclohexane/ethyl acetate, 8:2). At the end of the reaction, the mixture was cooled at room temperature and quenched with $\mathrm{CH}_{3} \mathrm{OH}(1 \mathrm{~mL})$. The mixture was acidified with glacial acetic acid and poured into water (150-200 mL). The suspension was stirred and once the precipitate was formed, filtrated to obtain a yellow precipitate that was dried overnight under vacuum to yield $0.511 \mathrm{~g}$ of yellow powder.

(8R,9S,13S,14S)-methyl-7,8,9,11,12,13,14,15,16,17-decahydro-2-adamantyl-3-methoxy-13methyl-17-oxo-6H-cyclopenta[a]phenanthrene-16-carboxylate $(3)$. Yield $93 \% ; \mathrm{R}_{f}=0.30$ (cyclohexane/ethyl acetate, 8:2); $\mathrm{mp}=180-181^{\circ} \mathrm{C} ;{ }^{1} \mathrm{H} \mathrm{NMR}\left(300 \mathrm{MHz}, \mathrm{CDCl}_{3}\right): \delta 0.98(\mathrm{~s}, 3 \mathrm{H})$, $1.37(\mathrm{~m}, 1 \mathrm{H}), 1.51(\mathrm{~m}, 1 \mathrm{H}), 1.52(\mathrm{~m}, 1 \mathrm{H}), 1.57(\mathrm{~m}, 1 \mathrm{H}), 1.63(\mathrm{~m}, 1 \mathrm{H}), 1.65(\mathrm{~m}, 1 \mathrm{H}), 1.76(6 \mathrm{H})$, $1.85(\mathrm{~m}, 1 \mathrm{H}), 1.99(\mathrm{~m}, 1 \mathrm{H}), 2.03(\mathrm{~m}, 1 \mathrm{H}), 2.11(3 \mathrm{H}), 2.20-2.08(6 \mathrm{H}), 2.29(\mathrm{~m}, 1 \mathrm{H}), 2.44(\mathrm{~m}, 1 \mathrm{H})$, $2.88(\mathrm{~m}, 2 \mathrm{H}), 3.21(\mathrm{dd}, J=9.9,8.5 \mathrm{~Hz}, 1 \mathrm{H}), 3.76-3.79(\mathrm{~s}, 3 \mathrm{H}), 3.80(\mathrm{~s}, 3 \mathrm{H}), 6.61(\mathrm{~s}, 1 \mathrm{H}), 7.14 \mathrm{ppm}$ $(\mathrm{s}, 1 \mathrm{H}) ;{ }^{13} \mathrm{C} \mathrm{NMR}\left(75 \mathrm{MHz}, \mathrm{CDCl}_{3}\right): \delta 13.31,25.90,26.40,29.17,29.30,32.50,36.90,36.94$, $37.16,38.40,40.79,44.80,47.87,50.42,52.50,54.10,55.03,112.09,124.20,131.03,134.72$, 136.07, 156.87, 169.87, 212.05 ppm. HRMS (ESI-MS, $140 \mathrm{eV}): \mathrm{m} / \mathrm{z}\left[\mathrm{M}+\mathrm{H}^{+}\right]$calculated for $\mathrm{C}_{31} \mathrm{H}_{41} \mathrm{O}_{4}{ }^{+}, 477.3005$; found, 477.3015 .

(8R,9S,13S,14S)-methyl7,8,9,11,12,13,14,15,16,17-decahydro-3-methoxy-13-methyl-17-oxo-

$6 \boldsymbol{H}$-cyclopenta $[\boldsymbol{a}]$ phenanthrene-16-carboxylate (9). Compound 9 was prepared as for compound 3 by reacting compound 1 (1.045 g; $3.674 \mathrm{mmol})$ with dimethyl carbonate $(26.9 \mathrm{~mL}, 319 \mathrm{mmol})$ and $\mathrm{NaH}\left(0.768 \mathrm{~g}, 32.01 \mathrm{mmol}\right.$ ). Yield 93\%; $\mathrm{R}_{f}=0.33$ (hexane/ethyl acetate, 8:2); ${ }^{1} \mathrm{H}-\mathrm{NMR}(300$ $\left.\mathrm{MHz}, \mathrm{CDCl}_{3}\right): \delta 0.98(\mathrm{~s}, 3 \mathrm{H}), 1.37(\mathrm{~m}, 1 \mathrm{H}), 1.51(\mathrm{~m}, 1 \mathrm{H}), 1.52(\mathrm{~m}, 1 \mathrm{H}), 1.57(\mathrm{~m}, 1 \mathrm{H}), 1.63(\mathrm{~m}$, 
1H), $1.65(\mathrm{~m}, 1 \mathrm{H}), 1.85(\mathrm{~m}, 1 \mathrm{H}), 1.99(\mathrm{~m}, 1 \mathrm{H}), 2.03(\mathrm{~m}, 1 \mathrm{H}), 2.29(\mathrm{~m}, 1 \mathrm{H}), 2.44(\mathrm{~m}, 1 \mathrm{H}), 2.88(\mathrm{~m}$, 2H), $3.21(\mathrm{dd}, J=9.9,8.5 \mathrm{~Hz}, 1 \mathrm{H}), 3.76-3.79(\mathrm{~s}, 3 \mathrm{H}), 3.80(\mathrm{~s}, 3 \mathrm{H}), 6.67(\mathrm{~d}, J=2.73 \mathrm{~Hz}, 1 \mathrm{H}), 6.75$ $(\mathrm{dd}, J=8.61 \mathrm{~Hz}, 2.73 \mathrm{~Hz}, 1 \mathrm{H}), 7.23 \mathrm{ppm}(\mathrm{d}, J=8.61 \mathrm{~Hz}, 1 \mathrm{H})$.

\section{(8R,9S,13S,14S)-methyl-7,8,9,11,12,13,14,15,16,17-decahydro-2-benzoyl-3-methoxy-13-}

methyl-17-oxo-6H-cyclopenta[a]phenanthrene-16-carboxylate (15). Compound 15 was prepared as for compound 3 by reacting compound 14 (1.259 g; $3.241 \mathrm{mmol})$ with dimethyl carbonate (23.7 $\mathrm{mL}, 281.5 \mathrm{mmol})$ and $\mathrm{NaH}(0.677 \mathrm{~g}, 28.23 \mathrm{mmol})$. An amount of $1.290 \mathrm{~g}$ of a crude product was obtained, and this was purified by silica gel flash column chromatography (hexane/ethyl acetate) to give $0.430 \mathrm{~g}$ of compound 15. Yield 33\%; $\mathrm{R}_{f}=0.35$ (hexane/ethyl acetate, $2: 1$ ); $\mathrm{mp}=114^{\circ} \mathrm{C}$;

${ }^{1} \mathrm{H}$ NMR (400 MHz, $\left.\mathrm{CDCl}_{3}\right): \delta$ 0.99-0.96 (m, 3H), 1.40(m, 1H), $1.41(\mathrm{~m}, 1 \mathrm{H}), 1.42(\mathrm{~m}, 1 \mathrm{H}), 1.45$ (m, 1H), $1.52(\mathrm{~m}, 1 \mathrm{H}), 1.90(\mathrm{~m}, 1 \mathrm{H}), 2.07(\mathrm{~m}, 1 \mathrm{H}), 2.07(\mathrm{~m}, 1 \mathrm{H}), 2.24(\mathrm{~m}, 1 \mathrm{H}), 2.26(\mathrm{~m}, 1 \mathrm{H}), 2.27$ (m, 1H), $2.91(\mathrm{~m}, 2 \mathrm{H}), 3.22(\mathrm{dd}, J=9.9,8.4 \mathrm{~Hz}, 1 \mathrm{H}), 3.68(\mathrm{~s}, 3 \mathrm{H}), 3.77(\mathrm{~s}, 3 \mathrm{H}), 6.70(\mathrm{~s}, 1 \mathrm{H}), 7.29$ (s, 1H), 7.39-7.46 (m, 2H); 7.50-7.57 (m, 1H), $7.81 \mathrm{ppm}(\mathrm{dd}, J=8.3,1.3 \mathrm{~Hz}, 2 \mathrm{H}) ;{ }^{13} \mathrm{C}$ NMR $(101$ $\left.\mathrm{MHz}, \mathrm{CDCl}_{3}\right): \delta 13.27 / 14.34,25.70,26.31,26.39,30.05,31.57 / 31.77,37.82,43.78,47.82,48.89$, $52.61,54.01,55.62,111.75,126.49$, 127.05, 128.09, 129.77, 131.75, 132.69, 138.14, 140.91, 155.54/155.56, 169.80/170.32, 196.48, 211.79 ppm. HRMS (ESI-MS, $140 \mathrm{eV}): \mathrm{m} / \mathrm{z}\left[\mathrm{M}+\mathrm{H}^{+}\right]$ calculated for $\mathrm{C}_{28} \mathrm{H}_{31} \mathrm{O}_{5}{ }^{+}$, 447.2171; found, 447.2157.

(8R,9S,13S,14S)-methyl 3-(benzyloxy)-7,8,9,11,12,13,14,15,16,17-decahydro-13-methyl-17-oxo6H-cyclopenta[a]phenanthrene-16-carboxylate (21). Compound 21 was prepared as for compound 3 by reacting compound 20 (3.301 g; $9.157 \mathrm{mmol})$ with dimethyl carbonate $(67.03 \mathrm{~mL}$, $795.46 \mathrm{mmol})$ and $\mathrm{NaH}(1.914 \mathrm{~g}, 79.78 \mathrm{mmol})$ to yield $3.104 \mathrm{~g}$ of yellow powder. Yield $81 \%$; $\mathrm{R}_{f}=$ 0.27 (hexane/ethyl acetate, 8:2); $\mathrm{mp}=155^{\circ} \mathrm{C} ;{ }^{1} \mathrm{H}$ NMR $\left(300 \mathrm{MHz}, \mathrm{CDCl}_{3}\right): \delta 0.98 \mathrm{ppm}(\mathrm{s}, 3 \mathrm{H})$, $1.45(\mathrm{~m}, 1 \mathrm{H}), 1.46(\mathrm{~m}, 1 \mathrm{H}), 1.48(\mathrm{~m}, 1 \mathrm{H}), 1.51(\mathrm{~m}, 1 \mathrm{H}), 1.62(\mathrm{~m}, 1 \mathrm{H}), 1.63(\mathrm{~m}, 1 \mathrm{H}), 1.98(\mathrm{~m}, 1 \mathrm{H})$, $2.03(\mathrm{~m}, 1 \mathrm{H}), 2.07(\mathrm{~m}, 1 \mathrm{H}), 2.25(\mathrm{~m}, 1 \mathrm{H}), 2.40(\mathrm{~m}, 1 \mathrm{H}), 2.89(\mathrm{~m}, 2 \mathrm{H}), 3.21(\mathrm{dd}, J=9.9,8.5 \mathrm{~Hz}$, $1 \mathrm{H}), 3.76(\mathrm{~s}, 3 \mathrm{H}), 5.04(\mathrm{~s}, 2 \mathrm{H}), 6.74(\mathrm{~d}, J=2.6 \mathrm{~Hz}, 1 \mathrm{H}), 6.79(\mathrm{dd}, J=8.6,2.7 \mathrm{~Hz}, 1 \mathrm{H}), 7.20(\mathrm{~d}, J=$ $8.5 \mathrm{~Hz}, 1 \mathrm{H}), 7.32(\mathrm{t}, J=7.1 \mathrm{~Hz}, 1 \mathrm{H}), 7.38(\mathrm{t}, J=7.3 \mathrm{~Hz}, 2 \mathrm{H}), 7.43 \mathrm{ppm}(\mathrm{d}, J=6.9 \mathrm{~Hz}, 2 \mathrm{H}) ;{ }^{13} \mathrm{C}-$ $\mathrm{NMR}\left(75 \mathrm{MHz}, \mathrm{CDCl}_{3}\right): \delta 13.29,25.78,26.54,29.56,31.94,36.90,37.94,43.99,47.95,48.94$, 52.57,54.07, 69.97, 112.47, 114.92, 126.32, 127.42, 127.87, 128.55, 132.00,137.22, 137.67, 156.94, 169.85, 212.90 ppm. HRMS (ESI-MS, $140 \mathrm{eV}$ ): $\mathrm{m} / \mathrm{z}\left[\mathrm{M}+\mathrm{H}^{+}\right]$calculated for $\mathrm{C}_{27} \mathrm{H}_{31} \mathrm{O}_{4}{ }^{+}, 419.2222$; found, 419.2237.

4.1.5 General procedure for the synthesis of derivatives $(\mathbf{4 , 1 0 , 1 6 , 2 2 )}$. As a typical procedure, the synthesis of methyl 17-hydroxy-2-adamantyl-3-methoxy-13-methyl-16-carboxylate 4 is described in detail. Compound $3(1,711 \mathrm{~g}, 3.59 \mathrm{mmol})$ was suspended in a mixture $\mathrm{THF} / \mathrm{CH}_{3} \mathrm{OH}$ 9:1 (20 mL). 
The mixture was cooled and stirred for $15 \mathrm{~min}$ at $0^{\circ} \mathrm{C}$, then $\mathrm{NaBH}_{4}(0.156 \mathrm{~g}, 4.12 \mathrm{mmol})$ was added carefully in portions. The temperature was maintained at $0^{\circ} \mathrm{C}$ and the reaction was monitored by TLC analysis (eluent cyclohexane/ethyl acetate, 2:1). The reaction was completed in $0.5 \mathrm{~h}$. The mixture was acidified with $\mathrm{HCl} 2 \mathrm{~N}$ solution and extracted with ethyl acetate. The combined organic phases were washed with brine, dried over sodium sulphate, filtered and evaporated to dryness to yield $1.725 \mathrm{~g}$ of spongy solid. The crude product was purified by silica gel flash column chromatography (hexane/ethyl acetate) to give $1.53 \mathrm{~g}$ of white solid.

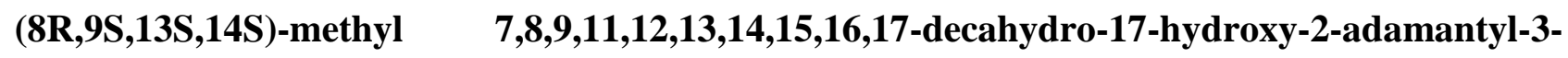
methoxy-13-methyl-6H-cyclopenta[a]phenanthrene-16-carboxylate (4). Yield 90\%; $\mathrm{R}_{f}=0.57$ (hexane/ethyl acetate, $2: 1) ; \mathrm{mp}=210-211^{\circ} \mathrm{C} ;{ }^{1} \mathrm{H}$ NMR $\left(300 \mathrm{MHz}, \mathrm{CDCl}_{3}\right): \delta 0.83(\mathrm{~s}, 3 \mathrm{H}), 1.18(\mathrm{~m}$, $1 \mathrm{H}), 1.32(\mathrm{~m}, 1 \mathrm{H}), 1.35(\mathrm{~m}, 1 \mathrm{H}), 1.45(\mathrm{~m}, 1 \mathrm{H}), 1.55(\mathrm{~m}, 1 \mathrm{H}), 1.68(\mathrm{~m}, 1 \mathrm{H}), 1.76(6 \mathrm{H}), 1.91(\mathrm{~m}, 1 \mathrm{H})$, $1.80(\mathrm{~m}, 1 \mathrm{H}), 2.02(\mathrm{~m}, 1 \mathrm{H}), 2.02(3 \mathrm{H}), 2.10(6 \mathrm{H}), 2.32(\mathrm{~m}, 1 \mathrm{H}), 2.35(\mathrm{~m}, 1 \mathrm{H}), 2.83(\mathrm{~m}, 2 \mathrm{H}), 3.14$ (dd, $J=18.7,9.1 \mathrm{~Hz}, 1 \mathrm{H}), 3.72(\mathrm{~s}, 3 \mathrm{H}), 3.80(\mathrm{~s}, 3 \mathrm{H}), 3.89$ (d, $J=10.0 \mathrm{~Hz}, 1 \mathrm{H}), 6.59$ (s, 1H), 7.16 ppm (s, 1H); ${ }^{13} \mathrm{C}$ NMR $\left(300 \mathrm{MHz}, \mathrm{CDCl}_{3}\right): \delta 11.67,26.71,27.25,27.74,29.48,29.71,37.24,37.49$, 37.62, 38.72, 41.11, 44.44, 44.57, 44.69, 48.96, 52.04, 55.10, 82.16, 112.39, 124.03, 131.70, 135.07, 136.25, 156.87, $175.94 \mathrm{ppm}$. HRMS (ESI-MS, $140 \mathrm{eV}): \mathrm{m} / \mathrm{z}\left[\mathrm{M}+\mathrm{H}^{+}\right]$calculated for $\mathrm{C}_{31} \mathrm{H}_{43} \mathrm{O}_{4}{ }^{+}, 479.3161$; found, 479.3149 .

(8R,9S,13S,14S)-methyl

7,8,9,11,12,13,14,15,16,17-decahydro-17-hydroxy-3-methoxy-13methyl-6H-cyclopenta[a]phenanthrene-16-carboxylate $(\mathbf{1 0})$. Compound $\mathbf{1 0}$ was prepared as for compound 4 by reacting compound 9 (1.195, 3.49 mmol) with $\mathrm{NaBH}_{4}(0.151 \mathrm{~g}, 4.005 \mathrm{mmol})$ for $0.5 \mathrm{~h}$, to give $1.166 \mathrm{~g}$ of spongy solid. The crude product was purified by silica gel flash column chromatography (hexane/ethyl acetate) to give $0.717 \mathrm{~g}$ of white solid. Yield $60 \% ; \mathrm{R}_{f}=0.53$ (hexane/ethyl acetate, 2:1); ${ }^{1} \mathrm{H}$ NMR $\left(300 \mathrm{MHz}, \mathrm{CDCl}_{3}\right): \delta 0.83(\mathrm{~s}, 3 \mathrm{H}), 1.18(\mathrm{~m}, 1 \mathrm{H}), 1.32(\mathrm{~m}$, 1H), $1.35(\mathrm{~m}, 1 \mathrm{H}), 1.45(\mathrm{~m}, 1 \mathrm{H}), 1.57(\mathrm{~m}, 1 \mathrm{H}), 1.63(\mathrm{~m}, 1 \mathrm{H}), 1.68(\mathrm{~m}, 1 \mathrm{H}), 1.85(\mathrm{~m}, 1 \mathrm{H}), 1.99(\mathrm{~m}$, $1 \mathrm{H}), 2.02(\mathrm{~m}, 1 \mathrm{H}), 2.32(\mathrm{~m}, 1 \mathrm{H}), 2.35(\mathrm{~m}, 1 \mathrm{H}), 2.83(\mathrm{~m}, 2 \mathrm{H}), 3.14(\mathrm{dd}, J=18.7,9.1 \mathrm{~Hz}, 1 \mathrm{H}), 3.72$ (s, 3H), $3.80(\mathrm{~s}, 3 \mathrm{H}), 3.88(\mathrm{~d}, J=10.0 \mathrm{~Hz}, 1 \mathrm{H}), 6.67(\mathrm{~d}, J=2.73 \mathrm{~Hz}, 1 \mathrm{H}), 6.75(\mathrm{dd}, J=8.61 \mathrm{~Hz}$, $2.73 \mathrm{~Hz}, 1 \mathrm{H}), 7.23 \mathrm{ppm}(\mathrm{d}, J=8.61 \mathrm{~Hz}, 1 \mathrm{H})$.

(8R,9S,13S,14S)-methyl

2-benzoyl-7,8,9,11,12,13,14,15,16,17-decahydro-17-hydroxy-3methoxy-13-methyl-6H-cyclopenta[a]phenanthrene-16-carboxylate (16). Compound 16 was prepared as for compound 4 by reacting compound $15(0.564 \mathrm{~g}, 1.263 \mathrm{mmol})$ with $\mathrm{NaBH}_{4}(0.055 \mathrm{~g}$, $1.449 \mathrm{mmol}$ ) for $0.25 \mathrm{~h}$, to give $0.553 \mathrm{~g}$ of spongy solid. Yield $97 \%$; $\mathrm{R}_{f}=0.54$ (hexane/ethyl acetate, $1: 1) ; \mathrm{mp}=250{ }^{\circ} \mathrm{C} ;{ }^{1} \mathrm{H}$ NMR $\left(400 \mathrm{MHz}, \mathrm{CDCl}_{3}\right): \delta 0.84(\mathrm{~s}, 3 \mathrm{H}), 1.23(\mathrm{~m}, 1 \mathrm{H}), 1.31(\mathrm{~m}, 1 \mathrm{H})$, $1.31(\mathrm{~m}, 1 \mathrm{H}), 1.47(\mathrm{~m}, 1 \mathrm{H}), 1.70(\mathrm{~m}, 1 \mathrm{H}), 1.87(\mathrm{~m}, 1 \mathrm{H}), 1.87(\mathrm{~m}, 1 \mathrm{H}), 1.93(\mathrm{~m}, 1 \mathrm{H}), 2.01(\mathrm{~m}, 1 \mathrm{H})$, $2.17(\mathrm{~m}, 1 \mathrm{H}), 2.98(\mathrm{~m}, 2 \mathrm{H}), 3.14(\mathrm{dd}, J=18.8,9.1 \mathrm{~Hz}, 1 \mathrm{H}), 3.67(\mathrm{~s}, 3 \mathrm{H}), 3.72(\mathrm{~s}, 3 \mathrm{H}), 3.87(\mathrm{~d}, J=$ 
$10.0 \mathrm{~Hz}, 1 \mathrm{H}), 6.68(\mathrm{~s}, 1 \mathrm{H}), 7.30(\mathrm{~s}, 1 \mathrm{H}), 7.42(\mathrm{t}, J=7.5 \mathrm{~Hz}, 2 \mathrm{H}), 7.54(\mathrm{t}, J=7.3 \mathrm{~Hz}, 1 \mathrm{H}), 7.83-$ $7.77 \mathrm{ppm}(\mathrm{m}, 2 \mathrm{H}) ;{ }^{13} \mathrm{C}-\mathrm{NMR}\left(101 \mathrm{MHz}, \mathrm{CDCl}_{3}\right): \delta 11.28,27.19,27.44,29.67 / 29.25,30.01$, 37.16/37.07, 38.14, 43.75, 44.05, 44.38, 48.65, 51.86, 55.64, 81.71, 111.76, 126.41, 127.16, 128.11/128.07, 129.79, 132.33, 132.59, 138.27, 141.02, 155.47, 175.41, 196.53 ppm. HRMS (ESIMS, $140 \mathrm{eV}): \mathrm{m} / \mathrm{z}\left[\mathrm{M}+\mathrm{H}^{+}\right]$calculated for $\mathrm{C}_{28} \mathrm{H}_{33} \mathrm{O}_{5}{ }^{+}$, 449.2328; found, 449.2548.

(8R,9S,13S,14S)-methyl 3-(benzyloxy)-7,8,9,11,12,13,14,15,16,17-decahydro-17-hydroxy-13methyl-6H-cyclopenta[a]phenanthrene-16-carboxylate (22). Compound 22 was prepared as for compound 4 by reacting compound 21 (3.104 g, $7.42 \mathrm{mmol}$ ) with $\mathrm{NaBH}_{4}(0.322 \mathrm{~g}, 8.52 \mathrm{mmol})$ for $0.5 \mathrm{~h}$, to give $3.586 \mathrm{~g}$ of orange solid. The crude product was purified by silica gel flash column chromatography (cyclohexane/ethyl acetate) to give $2.44 \mathrm{~g}$ of white solid. Yield $68 \% ; \mathrm{R}_{f}=0.45$ (cyclohexane/ethyl acetate, $2: 1) ; \mathrm{mp}=186^{\circ} \mathrm{C} ;{ }^{1} \mathrm{H} \mathrm{NMR}\left(300 \mathrm{MHz}, \mathrm{CDCl}_{3}\right): \delta 0.84 \mathrm{ppm}(\mathrm{s}, 3 \mathrm{H})$, $1.38(\mathrm{~m}, 1 \mathrm{H}), 1.41(\mathrm{~m}, 1 \mathrm{H}), 1.55(\mathrm{~m}, 1 \mathrm{H}), 1.56(\mathrm{~m}, 1 \mathrm{H}), 1.77(\mathrm{~m}, 1 \mathrm{H}), 1.90(\mathrm{~m}, 1 \mathrm{H}), 2.05(\mathrm{~m}, 1 \mathrm{H})$, $2.12(\mathrm{~m}, 1 \mathrm{H}), 2.26(\mathrm{~m}, 1 \mathrm{H}), 2.36(\mathrm{~m}, 1 \mathrm{H}), 2.89(\mathrm{~m}, 2 \mathrm{H}), 3.13(\mathrm{~m}, 1 \mathrm{H}), 3.73(\mathrm{~s}, 3 \mathrm{H}), 3.88(\mathrm{~d}, 1 \mathrm{H})$, $5.03(\mathrm{~s}, 2 \mathrm{H}), 6.72(\mathrm{~d}, J=2.7 \mathrm{~Hz}, 1 \mathrm{H}), 6.78(\mathrm{dd}, J=8.4,2.6 \mathrm{~Hz}, 1 \mathrm{H}), 7.20(\mathrm{~d}, J=8.5 \mathrm{~Hz}, 1 \mathrm{H}), 7.31$ $(\mathrm{dd}, J=8.5,5.9 \mathrm{~Hz}, 1 \mathrm{H}), 7.37(\mathrm{dd}, J=8.1,6.5 \mathrm{~Hz}, 2 \mathrm{H}), 7.43 \mathrm{ppm}(\mathrm{d}, J=6.9 \mathrm{~Hz}, 2 \mathrm{H}) ;{ }^{13} \mathrm{C}-\mathrm{NMR}$ $\left(75 \mathrm{MHz}, \mathrm{CDCl}_{3}\right): \delta 11.29,26.24,27.32,29.33,29.69,37.16,38.19,43.90,44.04,48.62,51.88$, $69.93,81.76,112.29,114.79,126.35,127.43,127.84,128.53,132.64,137.25,137.81,156.74$, $175.57 \mathrm{ppm}$. HRMS (ESI-MS, $140 \mathrm{eV}$ ): $\mathrm{m} / \mathrm{z}\left[\mathrm{M}+\mathrm{H}^{+}\right]$calculated for $\mathrm{C}_{27} \mathrm{H}_{33} \mathrm{O}_{4}{ }^{+}, 421.2379$; found, 421.2364 .

4.1.6 General procedure for the synthesis of derivatives $(\mathbf{6 , 1 2 , 1 8})$. As a typical procedure, the synthesis of methyl 2-adamantyl-3-methoxy-16-carboxylate derivative $\mathbf{6}$ is described in detail. In a double-necked round bottomed flask compound $4(0.659 \mathrm{~g}, 1.377 \mathrm{mmol})$ was dissolved in anhydrous $\mathrm{CH}_{2} \mathrm{Cl}_{2}$. Under a $\mathrm{N}_{2}$ atmosphere, triethylamine $(0.273 \mathrm{~mL}, 1.956 \mathrm{mmol})$ was added dropwise to the solution and then methanesulfonyl chloride $(0.112 \mathrm{~mL}, 1.456 \mathrm{mmol})$ was poured into the mixture. The obtained solution was stirred overnight. The mixture was then washed with water, saturated $\mathrm{NaHCO}_{3}$ solution, brine, filtered and evaporated under vacuum to yield a yellow solid (5). The obtained residue $(0.741 \mathrm{~g}, 1.331 \mathrm{mmol})$ was then dissolved in benzene $(20 \mathrm{~mL})$, and DBU $(0.397 \mathrm{~mL}, 2.662 \mathrm{mmol})$ was added. Under a $\mathrm{N}_{2}$ atmosphere, the reaction mixture was refluxed for $5 \mathrm{~h}$. The progress of the reaction was monitored by TLC analysis (hexane/ethyl acetate 2:1). Even though the reaction was not completed, the mixture was cooled and washed with equivalent volumes of $5 \% \mathrm{HCl}$ solution, brine and saturated $\mathrm{NaHCO}_{3}$ solution. The organic phase was evaporated to dryness under vacuum and the obtained crude product was purified by silica gel 
flash column chromatography (hexane/ethyl acetate) to give $0.179 \mathrm{~g}$ of white solid correspondent to the desired product (6) and $0.287 \mathrm{~g}$ of starting material.

(8S,9S,13S,14S)-methyl 7,8,9,11,12,13,14,15-octahydro-2-adamantyl-3-methoxy-13-methyl6H-cyclopenta $[a]$ phenanthrene-16-carboxylate $(6)$. Yield $60 \% ; \mathrm{R}_{f}=0.80$ (hexane/ethyl acetate, 2:1); mp = $179^{\circ} \mathrm{C} ;{ }^{1} \mathrm{H}$ NMR $\left(300 \mathrm{MHz}, \mathrm{CDCl}_{3}\right): \delta 0.88(\mathrm{~s}, 3 \mathrm{H}), 1.50(\mathrm{~m}, 1 \mathrm{H}), 1.63(\mathrm{~m}, 1 \mathrm{H}), 1.65$ $(\mathrm{m}, 1 \mathrm{H}), 1.70(\mathrm{~m}, 1 \mathrm{H}), 1.77(6 \mathrm{H}), 1.91(\mathrm{~m}, 1 \mathrm{H}), 1.97(\mathrm{~m}, 1 \mathrm{H}), 2.05(3 \mathrm{H}), 2.09-2.06(6 \mathrm{H}), 2.10(\mathrm{~m}$, 1H), $2.27(\mathrm{~m}, 1 \mathrm{H}), 2.37(\mathrm{~m}, 1 \mathrm{H}), 2.42(\mathrm{~m}, 1 \mathrm{H}), 2.58(\mathrm{~m}, 1 \mathrm{H}), 2.86(\mathrm{~m}, 2 \mathrm{H}), 3.76(\mathrm{~s}, 3 \mathrm{H}), 3.81(\mathrm{~s}$, $3 \mathrm{H}), 6.62(\mathrm{~s}, 1 \mathrm{H}), 6.92(\mathrm{~d}, J=1.7 \mathrm{~Hz}, 1 \mathrm{H}), 7.14(\mathrm{~s}, 1 \mathrm{H}) ;{ }^{13} \mathrm{C}-\mathrm{NMR}\left(75 \mathrm{MHz}, \mathrm{CDCl}_{3}\right): \delta 16.48$, 26.68, 28.13, 29.48, 29.55, 31.51, 35.38, 37.24, 37.49, 37.73, 41.11, 44.90, 47.50, 51.73, 55.30, 55.34, 112.44, 123.60, 131.85, 135.14, 135.26, 136.16, 155.12, 157.02, 166.78 ppm. HRMS (ESIMS, $140 \mathrm{eV}): \mathrm{m} / \mathrm{z}\left[\mathrm{M}+\mathrm{H}^{+}\right]$calculated for $\mathrm{C}_{31} \mathrm{H}_{41} \mathrm{O}_{3}{ }^{+}, 461.3056$; found, 461.3067.

$(8 S, 9 S, 13 S, 14 S)$-methyl

7,8,9,11,12,13,14,15-octahydro-3-methoxy-13-methyl-6Hcyclopenta $[a]$ phenanthrene-16-carboxylate (12). Compound 12 was prepared as for compound 6 by reacting compound $10(0.660 \mathrm{~g}, 1.916 \mathrm{mmol})$ with triethylamine $(0.379 \mathrm{~mL}, 2.722 \mathrm{mmol})$ and methanesulfonyl chloride $(0.119 \mathrm{~mL}, 2.026 \mathrm{mmol})$. The obtained crude product $11(0.659 \mathrm{~g}, 1.560$ mmol) was treated with DBU $(0.466 \mathrm{~mL}, 3.120 \mathrm{mmol})$ and after the work-up, it was purified by silica gel flash column chromatography (hexane/ethyl acetate) to give $0.523 \mathrm{~g}$ of white solid. Yield $84 \% ; \mathrm{R}_{f}=0.83$ (hexane/ethyl acetate, $\left.2: 1\right) ;{ }^{1} \mathrm{H} \mathrm{NMR}\left(300 \mathrm{MHz}, \mathrm{CDCl}_{3}\right): \delta 0.88(\mathrm{~s}, 3 \mathrm{H}), 1.50(\mathrm{~m}$, $1 \mathrm{H}), 1.63(\mathrm{~m}, 1 \mathrm{H}), 1.65(\mathrm{~m}, 1 \mathrm{H}), 1.70(\mathrm{~m}, 1 \mathrm{H}), 1.91(\mathrm{~m}, 1 \mathrm{H}), 1.97(\mathrm{~m}, 1 \mathrm{H}), 2.10(\mathrm{~m}, 1 \mathrm{H}), 2.27(\mathrm{~m}$, $1 \mathrm{H}), 2.37(\mathrm{~m}, 1 \mathrm{H}), 2.42(\mathrm{~m}, 1 \mathrm{H}), 2.58(\mathrm{~m}, 1 \mathrm{H}), 2.86(\mathrm{~m}, 2 \mathrm{H}), 3.76(\mathrm{~s}, 3 \mathrm{H}), 3.81(\mathrm{~s}, 3 \mathrm{H}), 6.67(\mathrm{~d}$, $1 \mathrm{H}), 6.75(\mathrm{~d}, J=1.7 \mathrm{~Hz}, 1 \mathrm{H}), 7.23 \mathrm{ppm}(\mathrm{d}, 1 \mathrm{H})$.

(8S,9S,13S,14S)-methyl $\quad 7,8,9,11,12,13,14,15$-octahydro-2-benzoyl-3-methoxy-13-methyl-6Hcyclopenta $[a]$ phenanthrene-16-carboxylate (18). Compound 18 was prepared as for compound 6 by reacting compound $16(0.656 \mathrm{~g}, 1.462 \mathrm{mmol})$ with triethylamine $(0.289 \mathrm{~mL}, 2.077 \mathrm{mmol})$ and methanesulfonyl chloride $(0.119 \mathrm{~mL}, 1.546 \mathrm{mmol})$. The obtained crude product $17(0.495 \mathrm{~g}, 0.940$ mmol) was treated with DBU $(0.317 \mathrm{~mL}, 2.126 \mathrm{mmol})$ and after the work-up, it was purified by silica gel flash column chromatography (hexane/ethyl acetate) to give $0.104 \mathrm{~g}$ of white solid. Yield 21\%; $\mathrm{R}_{f}=0.66$ (hexane/ethyl acetate, $\left.2: 1\right) ; \mathrm{mp}=107^{\circ} \mathrm{C} ;{ }^{1} \mathrm{H}$ NMR $\left(300 \mathrm{MHz}, \mathrm{CDCl}_{3}\right): \delta 0.91(\mathrm{~s}$, $3 \mathrm{H}), 1.54(\mathrm{~m}, 1 \mathrm{H}), 1.61(\mathrm{~m}, 1 \mathrm{H}), 1.68(\mathrm{~m}, 1 \mathrm{H}), 1.72(\mathrm{~m}, 1 \mathrm{H}), 1.74(\mathrm{~m}, 1 \mathrm{H}), 1.90(\mathrm{~m}, 1 \mathrm{H}), 2.04(\mathrm{~m}$, 1H), $2.35(\mathrm{~m}, 1 \mathrm{H}), 2.38(\mathrm{~m}, 1 \mathrm{H}), 2.39(\mathrm{~m}, 1 \mathrm{H}), 2.60(\mathrm{~m}, 1 \mathrm{H}), 2.89(\mathrm{~m}, 2 \mathrm{H}), 3.68(\mathrm{~s}, 3 \mathrm{H}), 3.71(\mathrm{~s}$, $3 \mathrm{H}), 6.65(\mathrm{~s}, 1 \mathrm{H}), 6.85(\mathrm{~d}, J=1.8 \mathrm{~Hz}, 1 \mathrm{H}), 7.22(\mathrm{~s}, 1 \mathrm{H}), 7.44(\mathrm{t}, J=7.4 \mathrm{~Hz}, 2 \mathrm{H}), 7.58-7.50(\mathrm{~m}$, 1H), 7.84 - $7.77(\mathrm{~m}, 2 \mathrm{H}) ;{ }^{13} \mathrm{C}-\mathrm{NMR}\left(75 \mathrm{MHz}, \mathrm{CDCl}_{3}\right): \delta 15.95,26.04,27.65,29.99,31.23,34.78$, $37.10,43.95,46.99,51.54,54.88,55.60,111.57,126.47,126.79,128.09,129.83,132.52,132.59$, 
132.60, 134.72, 141.27, 154.60, 155.43, 166.51, 196.63 ppm. HRMS (ESI-MS, 140 eV): m/z [M + $\mathrm{H}^{+}$] calculated for $\mathrm{C}_{28} \mathrm{H}_{31} \mathrm{O}_{4}{ }^{+}, 431.2222$; found, 419.2473 .

\subsection{7 (8S,9S,13S,14S)-7,8,9,11,12,13,14,15-octahydro-2-adamantyl-3-methoxy-13-methyl-6H-} cyclopenta[a]phenanthrene-16-carboxylic acid (7). In a round bottomed flask, compound 6 (0.166g, $0.360 \mathrm{mmol})$ was dissolved in a mixture of $\mathrm{CH}_{2} \mathrm{Cl}_{2} / \mathrm{CH}_{3} \mathrm{OH}(9: 1)$, and then $2 \mathrm{~mL}$ of $3 \mathrm{M}$ methanolic $\mathrm{NaOH}$ solution were added. The mixture was stirred at room temperature for $96 \mathrm{~h}$. The progression of the reaction was monitored by TLC analysis (hexane/ethyl acetate 2:1). At the end of the reaction, $1 \mathrm{M} \mathrm{HCl}$ solution was added and the organic phase was extracted with $\mathrm{CHCl}_{3}$. The combined organic phases were washed with $1 \mathrm{M} \mathrm{HCl}$ solution, brine and dried over sodium sulphate. After filtration, the organic phase was evaporated to dryness to yield $0.153 \mathrm{~g}$ of white solid. Yield 95\%; $\mathrm{R}_{f}=0.49$ (hexane/ethyl acetate, 2:1); $\mathrm{mp}=$ over $300{ }^{\circ} \mathrm{C} ;{ }^{1} \mathrm{H}$ NMR $(300 \mathrm{MHz}$, $\left.\mathrm{CDCl}_{3}\right): \delta 0.89(\mathrm{~s}, 3 \mathrm{H}), 1.46(\mathrm{~m}, 1 \mathrm{H}), 1.58(\mathrm{~m}, 1 \mathrm{H}), 1.65(\mathrm{~m}, 1 \mathrm{H}), 1.72(\mathrm{~m}, 1 \mathrm{H}), 1.77(6 \mathrm{H}), 1.81(\mathrm{~m}$, 1H), $1.95(\mathrm{~m}, 1 \mathrm{H}), 2.03(\mathrm{~m}, 1 \mathrm{H}), 2.05(3 \mathrm{H}), 2.09-2.06(6 \mathrm{H}), 2.27(\mathrm{~m}, 1 \mathrm{H}), 2.36(\mathrm{~m}, 1 \mathrm{H}), 2.37(\mathrm{~m}$, 1H), $2.56(\mathrm{~m}, 1 \mathrm{H}), 2.88(\mathrm{~m}, 2 \mathrm{H}), 3.80(\mathrm{~s}, 3 \mathrm{H}), 6.61(\mathrm{~s}, 1 \mathrm{H}), 7.05(\mathrm{~d}, J=1.7 \mathrm{~Hz}, 1 \mathrm{H}), 7.14(\mathrm{~s}, 1 \mathrm{H})$; ${ }^{13} \mathrm{C}-\mathrm{NMR}\left(75 \mathrm{MHz}, \mathrm{CDCl}_{3}\right): \delta 16.38,26.65,28.13,29.46,29.59,31.19,35.20,37.22,37.47,37.72$, 41.09, 44.85, 47.79, 55.27, 55.35, 112.43, 123.62, 131.77, 134.74, 135.15, 136.19, 157.03, 157.88, $170.75 \mathrm{ppm}$. HRMS (ESI-MS, $140 \mathrm{eV}$ ): $\mathrm{m} / \mathrm{z}\left[\mathrm{M}+\mathrm{H}^{+}\right]$calculated for $\mathrm{C}_{30} \mathrm{H}_{39} \mathrm{O}_{3}{ }^{+}, 447.2899$; found, 447.2878. RP-C8 HPLC: $\mathrm{t}_{\mathrm{R}}=19.80 \mathrm{~min}, 98.9 \%(\mathrm{~A} \%)$.

\subsection{8 (8S,9S,13S,14S)-7,8,9,11,12,13,14,15-octahydro-2-adamantyl-3-hydroxy-13-methyl-6H-} cyclopenta $[a]$ phenanthrene-16-carboxylic acid (8). Compound $7(0.103 \mathrm{~g}, 0.217 \mathrm{mmol})$ was dissolved in $5 \mathrm{~mL}$ of NMP and treated with a suspension of $\mathrm{NaSCH}_{3}(0.092 \mathrm{~g}, 1.32 \mathrm{mmol})$ in $5 \mathrm{~mL}$ of NMP. The mixture was refluxed for $5 \mathrm{~h}$ and monitored by TLC analysis. Once the starting material spot disappeared on TLC, a mixture of water and ice was added, and then $1 \mathrm{M} \mathrm{HCl}$ solution until $\mathrm{pH}=1$. The mixture was extracted with ethyl acetate, washed with water, brine and dried over sodium sulphate. The solvent was evaporated under vacuum and the black residue obtained was dissolved with diluted $\mathrm{NH}_{3}$ solution. The solution was acidified again with $1 \mathrm{M} \mathrm{HCl}$ until $\mathrm{pH}=1$ to obtain a subtle precipitate. The suspension was centrifugated and the supernatant discarded. The obtained powder was dried to yield $0,057 \mathrm{~g}$ of final product. Yield $56 \% ; \mathrm{R}_{f}=0.49$ (hexane/ethyl acetate, 2:1); mp = over $300^{\circ} \mathrm{C} ;{ }^{1} \mathrm{H}$ NMR $\left(400 \mathrm{MHz}, \mathrm{CDCl}_{3}\right): \delta 0.89(\mathrm{~s}, 3 \mathrm{H}), 1.46(\mathrm{~m}, 1 \mathrm{H}), 1.72$ $(\mathrm{m}, 1 \mathrm{H}), 1.75(\mathrm{~m}, 1 \mathrm{H}), 1.76(\mathrm{~m}, 1 \mathrm{H}), 1.77(6 \mathrm{H}), 1.93(\mathrm{~m}, 1 \mathrm{H}), 1.97(\mathrm{~m}, 1 \mathrm{H}), 2.06(\mathrm{~m}, 1 \mathrm{H}), 2.07$ (3H), $2.11(6 \mathrm{H}), 2.30(\mathrm{~m}, 1 \mathrm{H}), 2.31(\mathrm{~m}, 1 \mathrm{H}), 2.42(\mathrm{~m}, 1 \mathrm{H}), 2.66(\mathrm{~m}, 1 \mathrm{H}), 2.88(\mathrm{~m}, 2 \mathrm{H}), 6.39(\mathrm{~s}, 1 \mathrm{H})$, $7.03(\mathrm{~d}, J=1.7 \mathrm{~Hz}, 1 \mathrm{H}), 7.12 \mathrm{ppm}(\mathrm{s}, 1 \mathrm{H}) .{ }^{13} \mathrm{C}-\mathrm{NMR}\left(101 \mathrm{MHz}, \mathrm{CDCl}_{3}\right): \delta 16.98,26.16,28.91$, 
$29.46,29.59,32.06,34.85,36.45,37.47,37.65,40.07,44.52,47.39,55.15,116.3,123.74,131.74$, 133.69, 134.19, 134.73, 151.14, 157.60, 168.99 ppm. HRMS (ESI-MS, $140 \mathrm{eV}): \mathrm{m} / \mathrm{z}\left[\mathrm{M}+\mathrm{H}^{+}\right]$ calculated for $\mathrm{C}_{29} \mathrm{H}_{37} \mathrm{O}_{3}{ }^{+}$, 433.2743; found, 433.2761. RP-C8 HPLC: $\mathrm{t}_{\mathrm{R}}=16.59 \mathrm{~min}, 99.1 \%$ (A\%).

\subsection{9 (8S,9S,13S,14S)-7,8,9,11,12,13,14,15-octahydro-2-benzoyl-3-hydroxy-13-methyl-6H-} cyclopenta[a]phenanthrene-16-carboxylic acid (19). Compound $18(0.124 \mathrm{~g}, 0.289 \mathrm{mmol})$ was dissolved in $5 \mathrm{~mL}$ DMF and treated with $\mathrm{NaSCH}_{3}(0.123 \mathrm{~g}, 1.759 \mathrm{mmol})$. The mixture was refluxed for $1 \mathrm{~h}$ and monitored by TLC analysis (hexane/ethyl acetate 1:1). Once the starting material spot disappeared on TLC, DMF was evaporated under vacuum and the residue was acidified with $1 \mathrm{M}$ $\mathrm{HCl}$. The mixture was extracted with ethyl acetate, washed with water, brine and dried over sodium sulphate. The solvent was evaporated under vacuum to give $0.074 \mathrm{~g}$ of a spongy yellow solid. The crude product was purified by RP-C18 flash column chromatography (tetrahydrofuran/water 8:2) to give a solid correspondent to the products: $25 \%$ 19a, 37,5\% 19b and 37\% 19c as approximately evaluated by ${ }^{1} \mathrm{H}-\mathrm{NMR}$. The mixture was further separated by a flash column chromatography (Ethyl acetate/hexane 8:2) yielding the desired compound $0.0185 \mathrm{~g}$. Overall yield $16 \%$; $\mathrm{mp}=$ over $300^{\circ} \mathrm{C}$; ${ }^{1} \mathrm{H}$ NMR $\left(300 \mathrm{MHz}, \mathrm{CDCl}_{3}\right): \delta 0.87(\mathrm{~s}, 3 \mathrm{H}), 1.56(\mathrm{~m}, 1 \mathrm{H}), 1.66(\mathrm{~m}, 1 \mathrm{H}), 1.68(\mathrm{~m}, 1 \mathrm{H}), 1.70(\mathrm{~m}$, 1H), $1.71(\mathrm{~m}, 1 \mathrm{H}), 1.91(\mathrm{~m}, 1 \mathrm{H}), 2.02(\mathrm{~m}, 1 \mathrm{H}), 2.31(\mathrm{~m}, 1 \mathrm{H}), 2.31(\mathrm{~m}, 1 \mathrm{H}), 2.36(\mathrm{~m}, 1 \mathrm{H}), 2.58(\mathrm{~m}$, 1H), $2.91(\mathrm{~m}, 2 \mathrm{H}), 6.69(\mathrm{~s}, 1 \mathrm{H}), 6.90(\mathrm{~d}, J=1.7 \mathrm{~Hz}, 1 \mathrm{H}), 7.28(\mathrm{~s}, 1 \mathrm{H}), 7.42(\mathrm{t}, J=7.4 \mathrm{~Hz}, 2 \mathrm{H}), 7.57$ - $7.50(\mathrm{~m}, 1 \mathrm{H}), 7.83$ - $7.78(\mathrm{~m}, 2 \mathrm{H}) ;{ }^{13} \mathrm{C}-\mathrm{NMR}\left(75 \mathrm{MHz}, \mathrm{CDCl}_{3}\right): \delta 16.09,26.11,27.56,29.98$, 31.16, 34.81, 37.12, 43.99, 47.10, 55.62, 111.77, 126.27, 126.78, 128.07, 129.79, 132.52, 132.61, 132.61, 134.88, 141.17, 154.67, 155.45, 166.40, 196.66 ppm. HRMS (ESI-MS, 140 eV): m/z [M + $\mathrm{H}^{+}$] calculated for $\mathrm{C}_{26} \mathrm{H}_{27} \mathrm{O}_{4}{ }^{+}$, 403.1909; found, 403.1889. RP-C8 HPLC: $\mathrm{t}_{\mathrm{R}}=17.75$ min, 98.7\% (A\%).

\subsubsection{0 (8R,9S,13S,14S)-methyl 7,8,9,11,12,13,14,15,16,17-decahydro-3,17-dihydroxy-13-} methyl-6H-cyclopenta[a]phenanthrene-16-carboxylate (25). Into a double-necked round bottomed flask, previously dried in oven, about $0.300 \mathrm{~g}$ of $\mathrm{Pd} / \mathrm{C} 10 \%$ and approximately $40 \mathrm{ml}$ of ethyl acetate were placed. After connecting the flask to an elastomer balloon containing hydrogen gas, the mixture was stirred at room temperature for $1 \mathrm{~h}$ to saturate the suspension of $\mathrm{Pd} / \mathrm{C}$ with hydrogen. Then, compound $22(2.121 \mathrm{~g}, 5.04 \mathrm{mmol})$ in $20 \mathrm{~mL}$ of ethyl acetate was added dropwise to the suspension, and the mixture was stirred under hydrogen at atmospheric pressure and heated by means of an oil bath at $50{ }^{\circ} \mathrm{C}$ for $8 \mathrm{~h}$, monitoring the progression of the reaction by TLC analysis (cyclohexane/ethyl acetate 2:1). At the end of the reaction the mixture was filtered, and the solution was concentrated to dryness on a rotavapor to give $1.550 \mathrm{~g}$ of white solid. Yield $93 \% ; \mathrm{R}_{f}=0.20$ 
(cyclohexane/ethyl acetate, 2:1); $\mathrm{mp}=125^{\circ} \mathrm{C}{ }^{1} \mathrm{H}$ NMR (300 MHz, DMSO-d6): $\delta 0.76$ (s, 3H), 1.14 $(\mathrm{m}, 1 \mathrm{H}), 1.21(\mathrm{~m}, 1 \mathrm{H}), 1.24(\mathrm{~m}, 1 \mathrm{H}), 1.25(\mathrm{~m}, 1 \mathrm{H}), 1.32(\mathrm{~m}, 1 \mathrm{H}), 1.41(\mathrm{~m}, 1 \mathrm{H}), 1.81(\mathrm{~m}, 1 \mathrm{H}), 1.82$ $(\mathrm{m}, 1 \mathrm{H}), 1.83(\mathrm{~m}, 1 \mathrm{H}), 2.11(\mathrm{~m}, 1 \mathrm{H}), 2.26(\mathrm{~m}, 1 \mathrm{H}), 2.71(\mathrm{~m}, 2 \mathrm{H}), 3.04(\mathrm{q}, J=8.7 \mathrm{~Hz}, 1 \mathrm{H}), 3.60(\mathrm{~s}$, $3 \mathrm{H}), 3.77(\mathrm{~s}, 1 \mathrm{H}), 5.00(\mathrm{dd}, J=8.8,5.4 \mathrm{~Hz}, 1 \mathrm{H}), 6.43(\mathrm{~d}, J=2.6 \mathrm{~Hz}, 1 \mathrm{H}), 6.50(\mathrm{dd}, J=8.4,2.5 \mathrm{~Hz}$, $1 \mathrm{H}), 7.03$ (d, $J=8.3 \mathrm{~Hz}, 1 \mathrm{H}), 8.99 \mathrm{ppm}(\mathrm{s}, 1 \mathrm{H}) ;{ }^{13} \mathrm{C}-\mathrm{NMR}$ (75 MHz, DMSO-d6): $\delta$ 12.11, 26.62, 27.46, 28.59, 29.63, 37.08, 38.71, 43.88, 44.53, 46.82, 48.94, 51.72, 80.89, 113.32, 115.38, 126.64, 130.85, 137.71, 155.37, $175.70 \mathrm{ppm}$. HRMS (ESI-MS, $140 \mathrm{eV}): \mathrm{m} / \mathrm{z}\left[\mathrm{M}+\mathrm{H}^{+}\right]$calculated for $\mathrm{C}_{20} \mathrm{H}_{27} \mathrm{O}_{4}^{+}, 331.1909$; found, 331.1901 .

\subsubsection{1 (8R,9S,13S,14S)-methyl 7,8,9,11,12,13,14,15,16,17-decahydro-3,17-dihydroxy-2-iodo-13-} methyl-6H-cyclopenta[a]phenanthrene-16-carboxylate (26). Compound 25 (1.550 g, 4.69 mmol), N-iodosuccinimide (1.161 g, $5.160 \mathrm{mmol})$, Indium (III) trifluoromethanesulfonate (0.264 g, $0.47 \mathrm{mmol}$ ) were mixed together and dissolved in acetonitrile. The mixture was stirred overnight in the dark (wrapped in foil) at room temperature. The progression of the reaction was monitored by TLC analysis (cyclohexane/ethyl acetate 1:1). At the end of the reaction water was added and the organic phase was extracted with ethyl acetate. The combined organic phases were washed with brine and dried over sodium sulphate. After filtration, the solvent was evaporated under vacuum to yield $2.183 \mathrm{~g}$ of yellow product. The product was purified by silica gel column chromatography $(d$ $=3 \mathrm{~cm}, l=35 \mathrm{~cm}, 230-400 \mathrm{mesh}$, eluent cyclohexane/ ethyl acetate 1:1) to yield $0.639 \mathrm{~g}$ of white product. Yield 30\%; $\mathrm{R}_{f}=0.66$ (cyclohexane/ethyl acetate, $\left.1: 1\right) ; \mathrm{mp}=179{ }^{\circ} \mathrm{C}{ }^{1} \mathrm{H} \mathrm{NMR}(300 \mathrm{MHz}$, $\left.\mathrm{CDCl}_{3}\right): \delta 0.82(\mathrm{~s}, 3 \mathrm{H}), 1.16(\mathrm{~m}, 1 \mathrm{H}), 1.31(\mathrm{~m}, 1 \mathrm{H}), 1.32(\mathrm{~m}, 1 \mathrm{H}), 1.48(\mathrm{~m}, 1 \mathrm{H}), 1.51(\mathrm{~m}, 1 \mathrm{H}), 1.76$ (m, 1H), $1.88(\mathrm{~m}, 1 \mathrm{H}), 2.05(\mathrm{~m}, 1 \mathrm{H}), 2.09(\mathrm{~m}, 1 \mathrm{H}), 2.16(\mathrm{~m}, 1 \mathrm{H}), 2.24(\mathrm{~m}, 1 \mathrm{H}), 2.78(\mathrm{~m}, 2 \mathrm{H}), 3.13$ $(\mathrm{dd}, J=18.7,9.2 \mathrm{~Hz}, 1 \mathrm{H}), 3.72(\mathrm{~s}, 3 \mathrm{H}), 3.88(\mathrm{~d}, J=10.1 \mathrm{~Hz}, 1 \mathrm{H}), 5.74$ (s br, 1H), 6.68 (s, 1H), 7.51 ppm (s, 1H); ${ }^{13} \mathrm{C}$ NMR (75 MHz, $\left.\mathrm{CDCl}_{3}\right): \delta 11.33,26.28,27.10,29.23,29.28,37.02,37.94,43.52$, $44.15,45.99$, 48.53, 51.99, 81.68, 82.23, 115.00, 134.75, 135.20, 138.94, 152.83, 175.63 ppm. HRMS (ESI-MS, $140 \mathrm{eV}$ ): m/z [M + $\left.\mathrm{H}^{+}\right]$calculated for $\mathrm{C}_{20} \mathrm{H}_{26} \mathrm{IO}_{4}{ }^{+}, 457.0876$; found, 457.0853 .

4.1.12General procedure for the synthesis of derivatives $(\mathbf{2 7}, \mathbf{2 8}, \mathbf{2 9})$. As a typical procedure, the synthesis of $(8 \mathrm{R}, 9 \mathrm{~S}, 13 \mathrm{~S}, 14 \mathrm{~S})$-methyl 7,8,9,11,12,13,14,15,16,17-decahydro-3,17-dihydroxy-13methyl-2-(4-byphenyl)-6H-cyclopenta[a]phenanthrene-16-carboxylate 27 is described in detail. Compound 26 (0.200 g, $0.438 \mathrm{mmol})$ was dissolved in dioxane $(2 \mathrm{~mL})$ and then biphenyl boronic acid $(0.174 \mathrm{~g}, \quad 0.880 \mathrm{mmol})$, potassium carbonate $(0.243 \mathrm{~g}, \quad 1.760 \mathrm{mmol})$ and tetrakis(triphenylphosphine)palladium (0) $(0.050 \mathrm{~g}, 0.045 \mathrm{mmol})$ were added. The mixture was microwave irradiated at $160^{\circ} \mathrm{C}$ (power set point $250 \mathrm{~W}$, ramp time $60 \mathrm{sec}$, hold time $30 \mathrm{~min}$ ). The 
reaction progression was monitored by TLC analysis (hexane/ethyl acetate 1:1). At the end of the reaction, the mixture was diluted with water $(10 \mathrm{~mL})$ and extracted with ethyl acetate. The combined organic phases were dried over sodium sulphate, filtered and the solvent removed under vacuum. The crude product was purified by silica gel flash-column chromatography (hexane/ethyl acetate) to give $0.081 \mathrm{~g}$ of compound 27.

(8R,9S,13S,14S)-methyl 7,8,9,11,12,13,14,15,16,17-decahydro-3,17-dihydroxy-13-methyl-2-(4byphenyl)-6H-cyclopenta[ $\boldsymbol{a}]$ phenanthrene-16-carboxylate $\quad(27)$ Yield $33 \% ; \quad \mathrm{R}_{f}=0.54$ (hexane/ethyl acetate, $1: 1) ; \mathrm{mp}=232^{\circ} \mathrm{C} ;{ }^{1} \mathrm{H}$ NMR (400 MHz, MeOD-d $): \delta 0.94(\mathrm{~s}, 3 \mathrm{H}), 1.46(\mathrm{~m}$, 1H), $1.65(\mathrm{~m}, 1 \mathrm{H}), 1.69(\mathrm{~m}, 1 \mathrm{H}), 1.79(\mathrm{~m}, 1 \mathrm{H}), 1.81(\mathrm{~m}, 1 \mathrm{H}), 1.85(\mathrm{~m}, 1 \mathrm{H}), 1.90(\mathrm{~m}, 1 \mathrm{H}), 1.91(\mathrm{~m}$, 1H), $1.93(\mathrm{~m}, 1 \mathrm{H}), 2.03(\mathrm{~m}, 1 \mathrm{H}), 2.65(\mathrm{~m}, 1 \mathrm{H}), 2.74(\mathrm{~m}, 1 \mathrm{H}), 2.76(\mathrm{~m}, 1 \mathrm{H}), 2.95(\mathrm{~m}, 1 \mathrm{H}), 3.70(\mathrm{~s}$, $3 \mathrm{H}), 3.82$ (d, $J=10.5 \mathrm{~Hz}, 1 \mathrm{H}), 6.75$ (s, 1H), 7.39 (s, 1H), 7.41 (m, AA'BB', 2H), 7.45 (m, AA'BB', 2H), $7.62(\mathrm{~m}, 1 \mathrm{H}), 7.68(\mathrm{~m}, 2 \mathrm{H}), 7.65(\mathrm{~m}, 2 \mathrm{H}) \mathrm{ppm} .{ }^{13} \mathrm{C}-\mathrm{NMR}$ (101 MHz, MeOD-d4): $\delta$ 11.64, 24.70, 26.41, 29.32, 34.27, 36.48, 39.02, 42.54, 44.97, 47.91, 53.39, 55.64, 84.23, 114.35, 127.01, 127.28, 127.50, 127.61, 127.67, 128.78, 129.03, 137.41, 138.56, 139.34, 140.25, 142.65, 158.70, $174.60 \mathrm{ppm}$. HRMS (ESI-MS, $140 \mathrm{eV}$ ): $\mathrm{m} / \mathrm{z}\left[\mathrm{M}+\mathrm{H}^{+}\right]$calculated for $\mathrm{C}_{32} \mathrm{H}_{35} \mathrm{O}_{4}{ }^{+}, 483.2535$; found, 483.2547.

(8R,9S,13S,14S)-methyl 7,8,9,11,12,13,14,15,16,17-decahydro-3,17-dihydroxy-13-methyl-2-(4dibenzofuranyl)-6H-cyclopenta[ $[\boldsymbol{a}]$ phenanthrene-16-carboxylate (28). Compound 28 was prepared as for compound $\mathbf{2 7}$ by reacting compound 26 (0.308 g, $0.675 \mathrm{mmol})$ with 4(dibenzofuranyl)-boronic acid $(0.287 \mathrm{~g}, 1.356 \mathrm{mmol})$, potassium carbonate $(0.375 \mathrm{~g}, 2.710 \mathrm{mmol})$ and tetrakis(triphenylphosphine)palladium (0) (0.078 g, $0.068 \mathrm{mmol})$. The obtained crude product was purified by silica gel flash column chromatography (hexane/ethyl acetate) to give $0.129 \mathrm{~g}$ of white solid. Yield 42\%; $\mathrm{R}_{f}=0.53$ (hexane/ethyl acetate, $1: 1$ ); $\mathrm{mp}=215^{\circ} \mathrm{C} ;{ }^{1} \mathrm{H} \mathrm{NMR}(400 \mathrm{MHz}$, MeOD-d $)_{4}: \delta 0.80(\mathrm{~s}, 3 \mathrm{H}), 1.14(\mathrm{~m}, 1 \mathrm{H}), 1.15(\mathrm{~m}, 1 \mathrm{H}), 1.24(\mathrm{~m}, 1 \mathrm{H}), 1.31(\mathrm{~m}, 1 \mathrm{H}), 1.42(\mathrm{~m}, 1 \mathrm{H})$, $1.43(\mathrm{~m}, 1 \mathrm{H}), 1.52(\mathrm{~m}, 1 \mathrm{H}), 1.72(\mathrm{~m}, 1 \mathrm{H}), 1.94(\mathrm{~m}, 1 \mathrm{H}), 2.07(\mathrm{~m}, 1 \mathrm{H}), 2.24(\mathrm{~m}, 1 \mathrm{H}), 2.82(\mathrm{~m}, 2 \mathrm{H})$, $3.16(\mathrm{q}, J=6.82 \mathrm{~Hz}, 1 \mathrm{H}), 3.70(\mathrm{~s}, 3 \mathrm{H}), 3.91(\mathrm{~d}, J=5.07 \mathrm{~Hz}, 1 \mathrm{H}), 7.13(\mathrm{~d}, J=9.04 \mathrm{~Hz}, 1 \mathrm{H}), 7.59$ (d, $J=2.24 \mathrm{~Hz}, 1 \mathrm{H}), 7.65(\mathrm{dd}, J=9.12,1.94 \mathrm{~Hz}, 1 \mathrm{H}), 7.88(\mathrm{~m}, J=7.54,1.12 \mathrm{~Hz}, 1 \mathrm{H}), 7.98(\mathrm{~m}, J=$ 7.45, $0.98 \mathrm{~Hz}, 1 \mathrm{H}), 8.08$ (d, $J=8.94 \mathrm{~Hz}, 1 \mathrm{H}), 8.15$ (d, $J=9.14 \mathrm{~Hz}, 1 \mathrm{H}), 8.22$ (s, 1H), $8.55 \mathrm{ppm}(\mathrm{s}$, 1H). ${ }^{13} \mathrm{C}-\mathrm{NMR}$ (101 MHz, MeOD-d4): $\delta$ 10.45, 27.02, 27.76, 29.53, 30.01, 32.31, 38.45, 44.12, 45.02, 47.54, 47.35, 55.72, 82.01, 113.06, 124.23, 125.08, 125.10, 126.11, 126.40, 127.21, 128.05, 128.86, 130.09, 131.20, 134.89, 138.55, 139.71, 142.89, 149.81, 154.89, 159.11, 169.81 ppm. HRMS (ESI-MS, $140 \mathrm{eV}$ ): m/z [M + $\left.\mathrm{H}^{+}\right]$calculated for $\mathrm{C}_{32} \mathrm{H}_{33} \mathrm{O}_{5}{ }^{+}$, 497.2328; found, 497.2341.

(8R,9S,13S,14S)-methyl 7,8,9,11,12,13,14,15,16,17-decahydro-3,17-dihydroxy-13-methyl-2phenyl-6H-cyclopenta[a]phenanthrene-16-carboxylate (29). Compound 29 was prepared as for 
compound 27 by reacting compound $26(0.131 \mathrm{~g}, 0.287 \mathrm{mmol})$ with phenyl boronic acid $(0.070 \mathrm{~g}$, $0.577 \mathrm{mmol})$, potassium carbonate $(0.158 \mathrm{~g}, \quad 1.150 \mathrm{mmol})$ and tetrakis(triphenylphosphine)palladium (0) $(0.033 \mathrm{~g}, 0.029 \mathrm{mmol})$. The obtained crude product was purified by silica gel flash column chromatography (hexane/ethyl acetate) to give $0.081 \mathrm{~g}$ of white solid. Yield 26\%; $\mathrm{R}_{f}=0.47$ (hexane/ethyl acetate, $1: 1$ ); $\mathrm{mp}=240{ }^{\circ} \mathrm{C} ;{ }^{1} \mathrm{H}$ NMR $(400 \mathrm{MHz}, \mathrm{MeOD}-$ $\left.\mathrm{d}_{4}\right): \delta 0.89(\mathrm{~s}, 3 \mathrm{H}), 1.22(\mathrm{~m}, 1 \mathrm{H}), 1.34(\mathrm{~m}, 1 \mathrm{H}), 1.37(\mathrm{~m}, 1 \mathrm{H}), 1.54(\mathrm{~m}, 1 \mathrm{H}), 1.55(\mathrm{~m}, 1 \mathrm{H}), 1.91(\mathrm{~m}$, 1H), $1.94(\mathrm{~m}, 1 \mathrm{H}), 1.97(\mathrm{~m}, 1 \mathrm{H}), 2.23(\mathrm{~m}, 1 \mathrm{H}), 2.36(\mathrm{~m}, 1 \mathrm{H}), 2.41(\mathrm{~m}, 1 \mathrm{H}), 2.85(\mathrm{~m}, 2 \mathrm{H}), 3.18(\mathrm{q}, J$ $=8.8 \mathrm{~Hz}, 1 \mathrm{H}), 3.71(\mathrm{~s}, 3 \mathrm{H}), 3.96(\mathrm{~d}, J=10.5 \mathrm{~Hz}, 1 \mathrm{H}), 6.62(\mathrm{~s}, 1 \mathrm{H}), 7.14(\mathrm{~s}, 1 \mathrm{H}), 7.29-7.27(\mathrm{~m}$, 1H), $7.41-7.38(\mathrm{~m}, 2 \mathrm{H}), 7.54-7.51 \mathrm{ppm}(\mathrm{m}, 2 \mathrm{H}) ;{ }^{13} \mathrm{C} \mathrm{NMR}\left(101 \mathrm{MHz}, \mathrm{MeOD}-\mathrm{d}_{4}\right): \delta 10.74$, 26.17, 27.23, 28.30, 28.94, 37.36, 38.51, 43.91, 46.43, 48.30, 48.85, 50.78, 82.90, 115.51, 125.89, 126.08, 127.17, 127.65, 129.12, 131.38, 136.76, 139.31, 151.47, 176.20 ppm. ${ }^{13} \mathrm{C}-\mathrm{NMR}$ (101 MHz, MeOD-d4): $\delta 10.74,26.17,27.23,28.30,28.94,37.36,38.51,43.91,46.43,48.30,48.85,50.78$, $82.90,115.51,125.89,126.08,127.17,127.65,129.12,131.38,136.76,139.31,151.47,176.20$ ppm. HRMS (ESI-MS, $140 \mathrm{eV}$ ): $\mathrm{m} / \mathrm{z}\left[\mathrm{M}+\mathrm{H}^{+}\right]$calculated for $\mathrm{C}_{26} \mathrm{H}_{31} \mathrm{O}_{4}{ }^{+}, 407.2222$; found, 407.2234 .

4.1.13 General procedure for the synthesis of derivatives $(\mathbf{3 0}, \mathbf{3 1}, \mathbf{3 2})$. As a typical procedure, the synthesis of (8R,9S,13S,14S)-7,8,9,11,12,13,14,15,16,17-decahydro-3,17-dihydroxy-13-methyl-2(4-byphenyl)-6H-cyclopenta[a]phenanthrene-16-carboxylic acid $\mathbf{3 0}$ is described in detail. Compound 27 was dissolved in $8 \mathrm{~mL}$ of methanol and then $4 \mathrm{~mL}$ of $10 \% \mathrm{NaOH}$ solution were added. The mixture was heated to reflux for $1 \mathrm{~h}$ and monitored by TLC analysis (hexane/ ethyl acetate, 2:1). As the starting reagent spot disappeared, the solvent was reduced with rotavapor and the mixture acidified with concentrated $\mathrm{HCl}$ until $\mathrm{pH}=1$. The suspension was centrifugated and the supernatant discarded. The obtained powder was dried to yield $0,069 \mathrm{~g}$ of final product.

(8R,9S,13S,14S)-7,8,9,11,12,13,14,15,16,17-decahydro-3,17-dihydroxy-13-methyl-2-(4-

byphenyl)-6H-cyclopenta[ $\boldsymbol{a}]$ phenanthrene-16-carboxylic acid $(30)$. Yield $98 \%$; $\mathrm{mp}=$ over $300{ }^{\circ} \mathrm{C} ;{ }^{1} \mathrm{H}$ NMR $\left(400 \mathrm{MHz}, \mathrm{MeOD}-\mathrm{d}_{4}\right): \delta 0.94 \mathrm{ppm}(\mathrm{s}, 3 \mathrm{H}), 1.46(\mathrm{~m}, 1 \mathrm{H}), 1.65(\mathrm{~m}, 1 \mathrm{H}), 1.69(\mathrm{~m}$, $1 \mathrm{H}), 1.79(\mathrm{~m}, 1 \mathrm{H}), 1.81(\mathrm{~m}, 1 \mathrm{H}), 1.85(\mathrm{~m}, 1 \mathrm{H}), 1.90(\mathrm{~m}, 1 \mathrm{H}), 1.91(\mathrm{~m}, 1 \mathrm{H}), 1.93(\mathrm{~m}, 1 \mathrm{H}), 2.03(\mathrm{~m}$, $1 \mathrm{H}), 2.65(\mathrm{~m}, 1 \mathrm{H}), 2.74(\mathrm{~m}, 1 \mathrm{H}), 2.76(\mathrm{~m}, 1 \mathrm{H}), 2.95(\mathrm{~m}, 1 \mathrm{H}), 3.82(\mathrm{~d}, 1 \mathrm{H}), 6.77(\mathrm{~s}, 1 \mathrm{H}), 7.39(\mathrm{~s}$, 1H), 7.41 (m, AA'BB', 2H), 7.45 (m, AA'BB', 2H), 7.64 (m, 1H), 7.68 (m, 2H), 7.69 ppm (m, 2H); ${ }^{13} \mathrm{C}-\mathrm{NMR}$ (101 MHz, MeOD-d4): $\delta$ 11.12, 25.94, 26.17, 29.23, 34.16, 36.72, 38.98, 42.57, 44.89, $47.95,53.47,79.66,114.12,127.07,127.34,127.54,127.69,127.82,128.87,128.92,137.42$, 138.43, 139.24, 140.32, 142.68, 158.76, 177.55 ppm. HRMS (ESI-MS, $140 \mathrm{eV}): \mathrm{m} / \mathrm{z}\left[\mathrm{M}+\mathrm{H}^{+}\right]$ calculated for $\mathrm{C}_{31} \mathrm{H}_{33} \mathrm{O}_{4}{ }^{+}$, 469.2379; found, 469.2354. RP-C8 HPLC: $\mathrm{t}_{\mathrm{R}}=18.89 \min , 99.23 \%$ (A\%). 
(8R,9S,13S,14S)-7,8,9,11,12,13,14,15,16,17-decahydro-3,17-dihydroxy-13-methyl-2-(4-

dibenzofuranyl)-6H-cyclopenta[$[a]$ phenanthrene-16-carboxylic acid (31). Compound 31 was prepared as for compound 30. Yield 97\%; mp = over $300{ }^{\circ} \mathrm{C} ;{ }^{1} \mathrm{H}$ NMR (400 MHz, DMSO- $\left.\mathrm{d}_{6}\right): \delta$ $0.81(\mathrm{~s}, 3 \mathrm{H}), 1.14(\mathrm{~m}, 1 \mathrm{H}), 1.15(\mathrm{~m}, 1 \mathrm{H}), 1.24(\mathrm{~m}, 1 \mathrm{H}), 1.31(\mathrm{~m}, 1 \mathrm{H}), 1.42(\mathrm{~m}, 1 \mathrm{H}), 1.43(\mathrm{~m}, 1 \mathrm{H})$, $1.52(\mathrm{~m}, 1 \mathrm{H}), 1.72(\mathrm{~m}, 1 \mathrm{H}), 1.94(\mathrm{~m}, 1 \mathrm{H}), 2.07(\mathrm{~m}, 1 \mathrm{H}), 2.24(\mathrm{~m}, 1 \mathrm{H}), 2.82(\mathrm{~m}, 2 \mathrm{H}), 3.16(\mathrm{q}, J=$ $6.82 \mathrm{~Hz}, 1 \mathrm{H}), 3.91(\mathrm{~d}, J=5.07 \mathrm{~Hz}, 1 \mathrm{H}), 7.13(\mathrm{~d}, J=9.04 \mathrm{~Hz}, 1 \mathrm{H}), 7.59$ (d, $J=2.24 \mathrm{~Hz}, 1 \mathrm{H}), 7.65$ (dd, $J=9.12,1.94 \mathrm{~Hz}, 1 \mathrm{H}), 7.89(\mathrm{~m}, J=7.54,1.12 \mathrm{~Hz}, 1 \mathrm{H}), 7.98(\mathrm{~m}, J=7.45,0.98 \mathrm{~Hz}, 1 \mathrm{H}), 8.08$ $(\mathrm{d}, J=8.94 \mathrm{~Hz}, 1 \mathrm{H}), 8.15(\mathrm{~d}, J=9.14 \mathrm{~Hz}, 1 \mathrm{H}), 8.22(\mathrm{~s}, 1 \mathrm{H}), 8.59 \mathrm{ppm}(\mathrm{s}, 1 \mathrm{H}) ;{ }^{13} \mathrm{C}-\mathrm{NMR}(101$ MHz, DMSO-d $\left.{ }_{6}\right): \delta 10.94,26.98,27.88,29.72,30.04,32.24,38.74,44.17,45.09,47.53,47.88$, $82.04,113.12,124.12,125.06,125.07,126.15,126.34,127.93,128.01,128.92,130.14,131.24$, 134.93, 138.56, 139.72, 142.82, 149.82, 154.83, 159.14, 169.87 ppm. HRMS (ESI-MS, 140 eV): $\mathrm{m} / \mathrm{z}\left[\mathrm{M}+\mathrm{H}^{+}\right]$calculated for $\mathrm{C}_{31} \mathrm{H}_{31} \mathrm{O}_{5}{ }^{+}$, 483.2171; found, 483.2161. RP-C8 HPLC: $\mathrm{t}_{\mathrm{R}}=14.32 \mathrm{~min}$, $98.8 \%(\mathrm{~A} \%)$.

(8R,9S,13S,14S)-7,8,9,11,12,13,14,15,16,17-decahydro-3,17-dihydroxy-13-methyl-2-phenyl-6Hcyclopenta $[a]$ phenanthrene-16-carboxylic acid (32). Compound 32 was prepared as for compound 30. Yield 90\%; mp = over $300{ }^{\circ} \mathrm{C} ;{ }^{1} \mathrm{H}$ NMR (400 MHz, MeOD-d $)$ : $\delta 0.94$ (s, 3H), 1.46 $(\mathrm{m}, 1 \mathrm{H}), 1.65(\mathrm{~m}, 1 \mathrm{H}), 1.69(\mathrm{~m}, 1 \mathrm{H}), 1.79(\mathrm{~m}, 1 \mathrm{H}), 1.81(\mathrm{~m}, 1 \mathrm{H}), 1.85(\mathrm{~m}, 1 \mathrm{H}), 1.90(\mathrm{~m}, 1 \mathrm{H}), 1.91$ (m, 1H), $1.93(\mathrm{~m}, 1 \mathrm{H}), 2.03(\mathrm{~m}, 1 \mathrm{H}), 2.65(\mathrm{~m}, 1 \mathrm{H}), 2.74(\mathrm{~m}, 1 \mathrm{H}), 2.76(\mathrm{~m}, 1 \mathrm{H}), 2.95(\mathrm{~m}, 1 \mathrm{H}), 3.82$ $(\mathrm{d}, 1 \mathrm{H}), 6.88(\mathrm{~s}, 1 \mathrm{H}), 7.38(\mathrm{~s}, 1 \mathrm{H}), 7.40(\mathrm{~m}, 1 \mathrm{H}), 7.42(\mathrm{~m}, 2 \mathrm{H}), 7.45 \mathrm{ppm}(\mathrm{m}, 2 \mathrm{H}) ;{ }^{13} \mathrm{C}-\mathrm{NMR}(101$ MHz, MeOD-d4): $\delta$ 11.48, 26.12, 26.17, 29.42, 34.16, 36.72, 39.65, 42.57, 44.12, 47.93, 53.47, $79.66,113.01,127.69,127.81,128.87,128.92,129.04,137.42,138.76,139.24,158.76,177.52$ ppm. HRMS (ESI-MS, $140 \mathrm{eV}$ ): $\mathrm{m} / \mathrm{z}\left[\mathrm{M}+\mathrm{H}^{+}\right]$calculated for $\mathrm{C}_{25} \mathrm{H}_{29} \mathrm{O}_{4}{ }^{+}$, 393.2066; found, 393.2973. RP-C8 HPLC: $\mathrm{t}_{\mathrm{R}}=11.81 \mathrm{~min}, 99.1 \%(\mathrm{~A} \%)$.

\subsection{Biology}

\subsubsection{Cell viability assay}

Cell viability was determined by the 3-(4,5-dimethyl- thiazole-2-yl)-2,5-diphenyltetrazolium

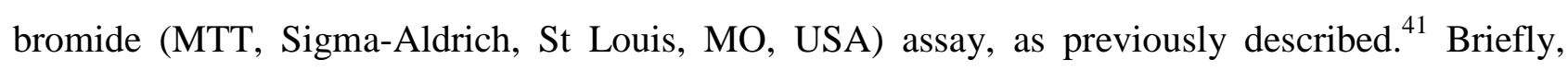
HepG2 cells were cultured in DMEM supplemented with $1 \%$ glutamine, pen-strep and 10\% FBS; cells were seeded in 96-multiwells culture plates at a concentration of (5000 cells/well) and treated with compounds 7, 8, 19a, 30, 31 and $32(6.25,12.5,25,50 \mu \mathrm{M})$ for $24 \mathrm{~h}$. The formazan absorbance was measured at $570 \mathrm{~nm}$, using a Multilabel Plate Reader VICTOR ${ }^{\text {TM }}$ X3 (Wallac Instruments, Turku, Finland). Three independent experiments were performed in quadruplicate. 


\subsubsection{Cell cycle distribution analysis}

Cell cycle distribution analysis was evaluated by flow cytometry (Epics XL, Beckmann Coulter) with CXP software, according to an already described method. ${ }^{42}$ Cells (200000 per well), 24 hours after seeding into 6 well-plates, were treated with compounds 7, 8, 19a, 31 at $20 \mu \mathrm{M}$ for $24 \mathrm{~h}$. The cells were washed with PBS and fixed with ethanol 70\%. After $15 \mathrm{~min}$ of incubation, cells were resuspended with RNase A $(0,1 \mathrm{mg} / \mathrm{mL})$ and $25 \mu \mathrm{L}$ of propidium iodide $(1 \mathrm{mg} / \mathrm{mL})$ for $15 \min$ at room temperature. The results of the different experiments were analyzed with CXP software. Three independent experiments were performed in duplicate.

\subsubsection{Evaluation of the estrogenic activity by qRT-PCR}

The estrogenic activity of the compounds 7, 8, 19a, 30, 31 and 32 was evaluated in the human breast adenocarcinoma cell line MCF-7 which highly expresses estrogen receptor (ER). ${ }^{43} \mathrm{MCF}-7$ cells were cultured in high glucose DMEM without phenol red supplemented with $1 \%$ glutamine, pen-strep and 10\% FBS, and seeded in 6-well culture plates at a concentration of (250000 cells/well). Samples were treated with compounds 7, 8, 19a, 30, 31 and $32(2 \mu \mathrm{M})$ for $24 \mathrm{~h}$. Estrone $(2 \mu \mathrm{M})$ was used as positive control. At the end of the incubation period, MCF-7 were scraped away from cell culture dishes and total RNA was extracted and purified by means of the SV Total RNA Isolation System (Promega Corporation, Madison, WI), as already described. ${ }^{44}$ Integrity and quantity of RNA were evaluated by an RNA 6000 Nano assay in an Agilent BioAnalyser (Agilent Technologies Inc., Palo Alto, CA, USA). The relative expression of GREB-1 and CXCL12, two genes which increase their transcription after the activation of $\mathrm{ER}^{45}$ was determined by real-time PCR (Eco ${ }^{\text {TM }}$ Illumina, Real-Time PCR system, San Diego, CA, USA) using One Step SYBR PrimeScript RT-PCR Kit (Takara Bio, Inc., Otsu, Shiga, Japan). PCR amplifications were tested for linearity and efficiency using standard curves obtained with serial dilution of cDNA; the specificity of amplification and absence of dimers were confirmed by melt-curve analysis. All genes were normalized to Glyceraldehyde-3-phosphate dehydrogenase (GAPDH). The primers used in this study are listed in Table 3. Expression levels of GREB-1 and CXCL12 genes were calculated by the $\Delta \Delta \mathrm{Ct}$ method using the Eco ${ }^{\mathrm{TM}}$ Software v4.0.7.0. Modifications of mRNA levels were expressed as fold variation compared with that of untreated cells. Three independent experiment were performed in triplicate. 


\begin{tabular}{lllll}
\hline Gene & Forward primer & Reverse primer & RefSeq & Size(bp) \\
\hline GREB-1 & 5'-gtt-ctg-aag-cta-gac-acg-ga-3' & 5'-ttg-agc-aatcgg-tcc-acc-aa-3' $^{\prime}$ & NM_014668.3 & 185 \\
CXCL12 & 5'-tac-aga-tgc-cca-tgc-cga-tt-3' & 5'-gaa-tcc-act-tta-gct-tcg-gg-3' & NM_000609.6 & 157 \\
GAPDH & 5'-aca-tca-aga-agg-tgg-tga-agc-a-3' & 5'-gtc-aaa-ggt-gga-gga-gtg-ggt-3' & NM_001289746.1 & 119 \\
\hline
\end{tabular}

Table 3. Primer sequences used in this study, NCBI reference sequences and amplicon sizes (base pairs).

\subsubsection{Cell transient transfection assays}

HEK293 cells were maintained in DMEM supplemented with 10\% FBS, 1\% penicillin and streptomycin. Cells were plated at a concentration of 30000/well in 96-well plates, according to an already described method. ${ }^{26}$ HEK293 cells were transiently transfected in OPTIMEM (Gibco) medium using lipofectamine 2000 (Invitrogen) following manufacturer instructions. Each plate was cotransfected with $0,2 \mu \mathrm{g}$ of Gal4-RORg LBD plasmid (Gal4-driven reporter assays), $0.1 \mu \mathrm{g}$ UASluciferase expression plasmid (both plasmids were kindly furnished by prof. Griffin) and $0.01 \mu \mathrm{g}$ of NanoLuc reporter plasmid (Promega, Italy). $6 \mathrm{~h}$ after transfection medium was replaced with DMEM supplemented with $1 \%$ FBS. The following day compounds 7, 8, 19a and 32 were added at different concentrations $(2,5,10,20 \mu \mathrm{M})$. Ursolic acid was used as a positive control. $48 \mathrm{~h}$ after transfection luminescence emission was measured using Nano-glo dual-luciferase reporter assay system (Promega) following manufacturer instructions with a Perkin Elmer en-vision system. All the assays were performed in triplicate, and the standard errors were calculated accordingly.

\subsubsection{Western blot analysis.}

Protein expression levels of ROR $\gamma t$ in transient transfected HEK293 cells was evaluated by Western blot analysis, as already described. ${ }^{46}$ Briefly, $20 \mu \mathrm{g}$ per lane of proteins were subjected to sodium dodecylsulfate polyacrylamide gel electrophoresis (SDS-PAGE) on 10\% polyacrylamide gels (100 $\mathrm{mV}$ for $15^{\prime}$ and $150 \mathrm{mV}$ for $90^{\prime}$ ) and transferred to a $0.45 \mu \mathrm{m}$ nitrocellulose membrane (Bio-Rad Laboratories S.r.l., Segrate, Milan, Italy) at $250 \mathrm{~mA}$ for $90 \mathrm{~min}$ in the presence of $25 \mathrm{mM}$ Tris - 192 $\mathrm{mM}$ glycine. Mouse monoclonal anti-ROR $\gamma$ (Millipore, Billerica, MA, USA) and rabbit polyclonal anti-GAPDH (Santa Cruz Biotechnology, Dallas, TX, USA) primary antibodies (both diluted 1:500) were used to detect ROR $\gamma \mathrm{t}$ and GAPDH (used as a loading control). Signal intensity of immunoreactive bands was analyzed by the Quantity One software (Bio-Rad Laboratories S.r.1.).

\subsubsection{Statistical analysis}

Comparison of the experimental data obtained from control cell cultures and those treated with the synthetic compounds was made by one-way analysis of variance (ANOVA). In the case of 
significant differences $(\alpha=0.05)$, the analysis of variance was followed by the Dunnett post-hoc test. $\mathrm{P}<0.05$ was considered statistically significant. If not otherwise stated, data are presented as mean \pm standard deviation.

\subsection{Molecular docking simulations}

The 3D structure of orphan nuclear receptor ROR $\gamma \mathrm{t}$ in complex with the inverse agonists, digoxin, was retrieved from the Protein Data Bank (www.rcsb.org, PDB code 3B0W).

Prior to docking simulation, protein structure was processed with Maestro 10.5 Protein Preparation tool using OPLS-2005 force field. Maestro $10.5^{47}$ Receptor Grid tool was used for the docking site identification, indicating bound digoxin as the grid centre and a length of $10 \AA$. Molecular structures of compounds 8 and 19a used for virtual docking were designed using the Builder tool of MOE 2015.10 48 and prepared for the docking simulation with Maestro $10.5^{47}$ Ligand Preparation tool using OPLS-2005 force field. The docking simulations were performed with Maestro $10.5^{47}$ Glide software SP precision, using flexible ligand sampling and performing post-docking minimization.

\section{REFERENCES}

1. P. Pawlak, B. Lefebvre, B. Staels. General Molecular Biology and Architecture of Nuclear Receptors. Curr. Top. Med. Chem. 2012; 12: 486-504.

2. A.A. Bogan, F.E. Cohen, T.S. Scanlan. Natural ligands of nuclear receptors have conserved volumes. Nat. Struct. Biol. 1998; 5: 679 - 681.

3. Zhong, C., Zhu, J. Small-Molecule ROR $\gamma$ t Antagonist: One Stone Kills Two Birds. Trends Immunol. 2017; 38: 229-231.

4. R. Mohan, and R. A. Heyman. Orphan nuclear receptor modulators. Curr. Top. Med. Chem. 2003; 3: 1637-1647.

5. J.R. Huh JR and D.R. Littman. Small molecule inhibitors of ROR $\gamma t$ : targeting Th17 cells and other applications. Eur. J. Immunol. 2012; 42: 2232-2237. 
6. B. P. Fauber, S. Magnuson, Modulators of the nuclear receptor retinoic acid receptor-related orphan receptor- $\gamma(\mathrm{ROR} \gamma$ or RORc). J. Med. Chem. 2014; 57: 5871-5892.

7. L. A. Solt, T. P. Burris, Action of RORs and their ligands in (patho)physiology. Trends Endocrinol. Metab. 2012; 23: 619-627.

8. N. Kumar, L. A. Solt, J. J. Conkright, Y. Wang, M. A. Istrate, S. A. Busby, R. D. GarciaOrdonez, T. P. Burris, P. R. Griffin, The benzenesulfonamide T0901317 [N-(2,2,2trifluoroethyl)-N-[4-[2,2,2-trifluoro-1-hydroxy-1-(trifluoromethyl)ethyl]phenyl]benzenesulfonamide] is a novel retinoic acid receptor-related orphan receptor-a/g inverse agonist. Mol. Pharmacol. 2010; 77: 228-236.

9. N. Mitro, L. Vargas, R. Romeo, A. Koder, E. Saez, T0901317 is a potent PXR ligand: implications for the biology ascribed to LXR. FEBS Lett. 2007; 581: 1721-1726.

10. L.A. Solt, N. Kumar, Y. He, T.M. Kamenecka, P.R. Griffin, T.P. Burris. Identification of a selective RORgamma ligand that suppresses TH17 cells and stimulates T regulatory cells. ACS Chem Biol. 2012; 71: 515-519.

11. N. Kumar, B. Lyda, M.R. Chang, J.L. Lauer, L.A. Solt, T.P. Burris, et al., Identification of SR2211: a potent synthetic RORgamma-selective modulator. ACS Chem Biol. 2012; 7: 672677.

12. Y. Wang, N. Kumar, P. Nuhant, M. D. Cameron, M.A. Istrate, W. R. Roush, P.R. Griffin, T. P. Burris. Identification of SR1078, a Synthetic Agonist for the Orphan Nuclear Receptors ROR $\alpha$ and ROR $\gamma$ t. ACS Chem. Biol. 2010; 5: 1029-1034

13. S. Xiao, N. Yosefi, J. Yang, Y. Wang, L. Zhou, C. Zhu, C. Wu, E. Baloglu, D.Schmidt, R. Ramesh, M. Lobera, M.S. Sundrud, P. Tsai, Z. Xiang, J. Wang, Y. Xu, X. Lin, K. Kretschmer, P. B. Rah, R. A. Young, Z. Zhong, D.A. Hafler, A. Regev, S. Ghosh, A. Marson, V. K. Kuchroo. Small molecule ROR $\gamma \mathrm{t}$ antagonists inhibit T helper 17 cell transcriptional network by divergent mechanisms. Immunity. 2014; 40(4): 477-489. 
14. J. Kallen, J.M. Schlaeppi, F. Bitsch, I. Delhon, B. Fournier. Crystal Structure of the Human ROR $\alpha$ Ligand Binding Domain in Complex with Cholesterol Sulfate at 2.2 A. J. Biol. Chem. 2004; 279: 14033-14038

15. S. Fujita-Sato, S. Ito, T. Isobe, T. Ohyama, K. Wakabayashi, K. Morishita, et al., Structural basis of digoxin that antagonizes RORgamma t receptor activity and suppresses Th17 cell differentiation and interleukin (IL)-17 production. J. Biol. Chem. 2011; 286: 31409-31417.

16. T. Xu, X. Wang, B. Zhong, R.I. Nurieva, S. Ding, C. Dong, Ursolic acid suppresses interleukin-17 (IL-17) production by selectively antagonizing the function of RORgamma t protein. J. Biol. Chem. 2011; 286: 22707-22710.

17. J.R. Huh, M.W. Leung, P. Huang, D.A. Ryan, M.R. Krout, R.R. Malapaka, et al., Digoxin and its derivatives suppress TH17 cell differentiation by antagonizing RORgammat activity. Nature. 2011; 472: 486-490.

18. Y. Wang, N. Kumar, L.A. Solt, T.I. Richardson, L.M. Helvering, C. Crumbley C, et al., Modulation of retinoic acid receptor-related orphan receptor alpha and gamma activity by 7 oxygenated sterol ligands. J.Biol.Chem. 2010; 285: 5013-5025.

19. L. Jin, D. Martynowski, S. Zheng, T. Wada, W. Xie, Y. Li, Structural basis for hydroxycholesterols as natural ligands of orphan nuclear receptor RORgamma. Mol. Endocrinol. 2010; 24: 923-929.

20. B.P. Fauber, O. Rene, G. de Leon Boenig, B. Burton, Y. Deng, C. Eidenschenk, et al., Reduction in lipophilicity improved the solubility, plasma-protein binding, and permeability of tertiary sulfonamide RORc inverse agonists. Bioorg. Med. Chem. Lett. 2014; 24: 38913897.

21. B.P. Fauber, G. de Leon Boenig, B. Burton, C. Eidenschenk, C. Everett, A. Gobbi A, et al., Structure-based design of substituted hexafluoroisopropanol-arylsulfonamides as modulators of RORc. Bioorg. Med. Chem. Lett. 2013; 23: 6604-6609. 
22. T. Yang, Q. Liu, Y. Cheng, W. Cai, Y. Ma, L. Yang, et al. Discovery of tertiary amine and indole derivatives as potent RORgammat inverse agonists. ACS Med. Chem. Lett. 2014; 5: $65-68$.

23. Y. Wang, N. Kumar, C. Crumbley, P.R. Griffin, T.P. Burris,.A second class of nuclear receptors for oxysterols: regulation of RORalpha and RORgamma activity by $24 \mathrm{~S}$ hydroxycholesterol (cerebrosterol). Biochim. Biophys. Acta. 2010; 1801: 917-923.

24. A. R de Lera, W.Bourguet, L. Altucci, H. Gronemeyer. Design of selective nuclear receptor modulators: RAR and RXR as a case study. Nat. Rev. Drug. Discov. 2007; 6: 811-820.

25. S. Xian, Z.U. Cai, L.L. Thio, J.S. Kim-Han, L.L. Dugan, D.F. Covey, S.M. Rothman. The estrogen receptor is not essential for all estrogen neuroprotection: new evidence from a new analog. Neurobiol. Dis. 2002; 9: 282-293; K.D. Yi, E. Perez, S. Yang, R. Liu, D. F. Covey, Simpkins JW,The assessment of non-feminizing estrogens for use in neuroprotection. Brain Res. 2011, 16, 1379:61-70; A.B. Petrone, J.W. Gatson, J.W. Simpkins, M.N. Reed. Nonfeminizing estrogens: a novel neuroprotective therapy. Mol. Cell Endocrinol. 2014 May 25, 389(0):40-47; M. Qian, E.B. Engler-Chiurazzi, S.E. Lewis, N.P. Rath J.W. Simpkins and D.F. Covey. Structure-activity studies of non-steroid analogues structurally-related to neuroprotective estrogens. Org. Biomol. Chem. 2016, 14, 9790-9805.

26. M.R. Chang, V. Dharmarajan, C. Doebelin, R.D. Garcia-Ordonez, S.J. Novick, D.S. Kuruvilla, T.M. Kamenecka, P.R. Griffin, Synthetic ROR $\gamma t$ Agonists Enhance Protective Immunity. ACS Chem. Biol. 2016; 11: 1012-1018.

27. H. M.Berman, J. Westbrook, Z. Feng, G. Gilliland, T.N. Bhat, H. Weissig, I. Shindyalov, N.; Bourne, P. E. The Protein Data Bank. Nucleic Acids Res. 2000, 28, 235-242

28. Li, C.; Qiua, W.; Yanga, Z.; Luoa, J.; Yanga, F.; Liua, M.; Xie, B; Tang, J. Stereoselective synthesis of some methyl-substituted steroid hormones and their in-vitro cytotoxic activity against human gastric cancer cell line MGC-803. Steroids, 2010, 75, 859-869.

29. W. H. W. Lunn and E. Farkas. The adamanthyl carbonium ion as a dehydrogenating agent, its reactions with estrone. Tetrahedron. 1968; 24: 6773-6776. 
30. U. Gozzi, G. Marnini. Cleavage of the D ring in 16-substituted steroids. Gazz. Chim. Ital., 1977; 107: 75-81.

31. N. Vicker; L. Harshani Rithma Ruchi; M.A. Allan, C. Bubert, D.S.M Fischer, A. Purohit, M.J. Reed, B.V.L Potter. Inventors: Sterix Ltd, N. Vicker, L.Harshani, Rithma Ruchi; M.A. Allan, C. Bubert; D.S.M Fischer, A, Purohit, M.J. Reed, B.V.L Potter, Assignee. 17betahydroxysteroid dehydrogenase inhibitors. WO2004085457 A2 2004

32. L.A. Paquette, K. Dahnke, J. Doyon, W. He, K. Wyant, D. Friedrichlc, Regioselective Conversion of Cycloalkanones to Vinyl Bromides with 1,2-Functionality Transposition. A General Stratagem. J. Org. Chem. 1991; 56: 6199-6205.

33. V. Theodorou, K. Skobridis, A.G. Tzakos, V. Ragoussis, A simple method for the alkaline hydrolysis of esters. Tetrahedron Lett. 2007; 48: 8230-8233.

34. B. Charpentier, J.M. Bernardon, J. Eustache, C. Millios, B. Martin, S. Michrl, B. Shroot, Synthesis, Structure-Affinity Relationships, and Biological Activities of Ligands Binding to Retinoic Acid Receptor Subtypes. J. Med. Chem. 1995; 38: 4993-5006.

35. G. Gondos, G. Dombi. Novel Friedel-Crafts Alkylation of Estrogens in the Presence of Anhydrous FeCl3 or FeCl3-Graphite as Catalyst. Monatsh Chem. 2002; 133: 1279-1283.

36. A. Suzuki, Carbon-carbon bonding made easy. Chem. Commun. 2005; 38: 4759-4763.

37. G.M. Allan, H.R. Lawrence, J. Cornet et al. Modification of estrone at the 6, 16, and 17 positions: novel potent inhibitors of 17ß-hydroxysteroid dehydrogenase type 1 . J. Med. Chem. 2006; 49: 1325-1345.

38. C. Zhou, J. Li; S. Peddibhotla, et al. Mild arming and derivatization of natural products via an In(OTf)3-catalyzed arene iodination. Org lett. 2010; 12: 2104-2107.

39. J. Lee, J.Y. Kim, K.S. Song, J. Kim, K.W. Ahn, Y. Kong; (+)-3-hydroxymorphinan derivatives as neuroprotectants. US 2012/0122848 2012. 
40. V. Theodorou; K. Skobridis; A.G. Tzakos; V. Ragoussis. A simple method for the alkaline hydrolysis of esters. Tetrahedron Lett. 2007; 09: 8230-8233.

41. D. Catanzaro, R. Filippini, C. Vianello, M. Carrara, E. Ragazzi, M. Montopoli; Chlorogenic acid interaction with cisplatin and oxaliplatin: studies in cervical carcinoma cells. Nat Prod Commun. 2016; 11(4): 499-502.

42. Catanzaro D, Ragazzi E, Vianello C, Caparrotta L, Montopoli M., Effect of Quercetin on Cell Cycle and Cyclin Expression in Ovarian Carcinoma and Osteosarcoma Cell Lines. Nat Prod Commun. 2015 Aug;10(8):1365-8.

43. L. Ponnusamy, P.K.S. Mahalingaiah, K.P. Singh, Treatment schedule and estrogen receptorstatus influence acquisition of doxorubicin resistance in breast cancer cells. Eur. J. Pharm. Sci. 2017; 104: 424-433.

44. G. Castellani, G. Paliuri, G. Orso, N. Paccagnella, C. D'Amore, L. Facci, et al., An intracellular adrenomedullin system reduces IL-6 release via a NF-kB-mediated, cAMPindependent transcriptional mechanism in rat thymic epithelial cells. Cytokines. 2016; 88: 136-143.

45. C.Y. Lin, A. Ström, V. Berlian Vega, S.L. Kong, A.L. Yeo, J.S. Thomsen, et al., Discovery of estrogen receptor $\alpha$ target genes and response elements in breast tumour cells. Genome Biol. 2004; 5 R66.

46. S. De Martin, D. Gabbia, G. Albertin, M.M. Sfriso, C. Mescoli, L. Albertoni, et al., Differential effect of liver cirrhosis on the pregnane $\mathrm{X}$ receptor-mediated induction of CYP3A1 and 3A2 in the rat. Drug Metab Dispos. 2014; 42:1617-1626.

47. Schrödinger Release 2016-1: MS Jaguar, Schrödinger, LLC, New York, NY, 2016.

48. Molecular Operating Environment (MOE), 2015.10; Chemical Computing Group ULC, 1010 Sherbooke St. West, Suite \#910, Montreal, QC, Canada, H3A 2R7, 2017. 
